\title{
Ida B. Wells, Catherine Impey, and trans -Atlantic dimensions of the nineteenth-century anti-lynching movement
}

\author{
Brucella Wiggins Jordan \\ West Virginia University
}

Follow this and additional works at: https://researchrepository.wvu.edu/etd

\section{Recommended Citation}

Jordan, Brucella Wiggins, "Ida B. Wells, Catherine Impey, and trans -Atlantic dimensions of the nineteenthcentury anti-lynching movement" (2003). Graduate Theses, Dissertations, and Problem Reports. 1845. https://researchrepository.wvu.edu/etd/1845

This Dissertation is protected by copyright and/or related rights. It has been brought to you by the The Research Repository @ WVU with permission from the rights-holder(s). You are free to use this Dissertation in any way that is permitted by the copyright and related rights legislation that applies to your use. For other uses you must obtain permission from the rights-holder(s) directly, unless additional rights are indicated by a Creative Commons license in the record and/ or on the work itself. This Dissertation has been accepted for inclusion in WVU Graduate Theses, Dissertations, and Problem Reports collection by an authorized administrator of The Research Repository @ WVU. For more information, please contact researchrepository@mail.wvu.edu. 
Ida B. Wells, Catherine Impey, and Trans-Atlantic Dimensions of the Nineteenth Century Anti-Lynching Movement

Brucella Wiggins Jordan

\author{
Dissertation submitted to the \\ Eberly College of Arts and Sciences \\ at West Virginia University \\ in partial fulfillment of the requirements \\ for the degree of
}

Doctor of Philosophy

in

History

Amos J. Beyan, Ph.D., Chair
Robert M. Maxon, Ph.D.
John McKivigan, Ph.D.
Barbara J. Howe, Ph.D.
Katherine O. Bankole, Ph.D.
Department of History

Morgantown, West Virginia

2003

Keywords: African American History, Anti-lynching Movement, Ida B. Wells,

Catherine Impey, British Anti-lynching Campaign

Copyright 2003 Brucella Wiggins Jordan 


\section{Abstract \\ Ida B. Wells, Catherine Impey, and Trans-Atlantic Dimensions of the Nineteenth Century Anti-Lynching Movement}

\section{Brucella Wiggins Jordan}

Unlike the majority of scholarship on the anti-lynching movement, this study focuses on the contribution and interaction of trans-Atlantic participants in the nineteenth century phase of the movement. According to current historiography, the origin of the antilynching movement is generally associated with the protest journalism of Ida B. Wells and her exile from the American South in 1892. This study however, redefines that date of origin as well as the period of time in which Americans and persons in the United Kingdom began working together to expose the crime of lynching beyond American shores. In this perspective, the activities of Ida B. Wells represent a catalytic force, which significantly impacted a nascent anti-lynching movement that had begun several years before she became involved.

The examination of correspondence, journals and periodicals, newspaper articles, diaries, membership data, and autobiographies, has shown that specific Americans were speaking out and organizing in protest of lynchings a decade prior to the traditionally designated time period, and that a trans-Atlantic connection was made with reform minded individuals in the United Kingdom at an earlier date than is usually stated. This discourse provides a clearly defined picture of the nineteenth century anti-lynching movement from its genesis in the early 1880 s to 1900 .

As the Reconstruction period came to an end, whites who were threatened by upward mobility in the African American community, began to use lynchings as a means of stifling their political, economic, and social advancement. In spite of the risk of speaking out against this aggression, several Americans, specifically journalists, ministers, and humanitarians asserted their influence and protested the crime. They were joined in their efforts by persons in the United Kingdom, primarily England and Scotland, who together increased the global awareness of a heinous crime and laid the foundation for future initiatives to abolish lynchings in American society. 


\section{ACKNOWLEDGMENTS}

My interest in the anti-lynching movement began in 1991 when I first read Crusade For Justice: The Autobiography of Ida B. Wells. Serious research began in 1993 when I was contracted by the Kansas Humanities Council to portray Ida B. Wells-Barnett as a historical character. That research led to this study.

The contributions of a number of people and institutions helped me to arrive at this point. First, I would like to thank the members of my dissertation committee: Dr. Amos Beyan, Dr. Robert Maxon, Dr. John McKivigan, Dr. Barbara Howe, and Dr. Katherine Bankole. I benefited from the expertise of each of them. In addition to scholarly assistance, I am grateful for the pragmatic perspective that I gained from Dr. Beyan. I extend a special thank you to Dr. McKivigan, my teacher in numerous Nineteenth Century American History courses. Thank you for being an excellent professor -- for broadening my multicultural learning experience, for your critical analysis of my work, and for your words of encouragement.

I was financially assisted in this research by a Minority Faculty Fellowship from Marshall University Graduate College in South Charleston, West Virginia. The fellowship funded my research in London, England. I am indebted to Dr. Joyce East and Dr. Ronald Childress for their contribution to that effort.

I was greatly assisted in my research by the librarians of West Virginia University, West Virginia State College, and Fairmont State College. The inter-library loan assistance that I received from Lois McCarthy and Beth Lewis of Marshall University Graduate College is of inestimable value. Thanks also to the librarians of the University of Chicago Reggenstein Library and the Carter G. Woodson Library in Chicago; the Library of Congress and National Archives in Washington, D.C.; and the Fawcett Library, the British Library, and the Friends House Library in London, England.

My research was helped by conversations with Alfreda Duster Ferrell, the granddaughter of Ida B. Wells-Barnett, and members of Asbury United Methodist Church of Holley Springs, Mississippi, who coincidentally were having an "Ida B. Wells Birthday Celebration Program," when I visited in July 1997.

I also wish to thank Dr. Betty-Lou Waters and Lisa Maldonado for their editorial suggestions, and my special cheering committee -- the members of my family. Most specifically my children, Sheri, Eric, Gandhi, Lionel, and my husband Norman, who propped me up when I needed it and never doubted my ability to complete this project. 


\section{Contents}

INTRODUCTION 1

1. Catherine Impey: Neo-Abolitionist Extraordinaire 39

2. T. Thomas Fortune and the Afro-American League 76

3. Albion Winegar Tourgee: Radical Republican and Civil Rights Advocate

100

4. $\underline{\text { Anti-Caste }} 120$

5. A Quickening of the Movement: Enter Ida B. Wells 157

6. Expanding Trans-Atlantic Connections: Ida B. Wells in the United Kingdom

7. Fraternity

223

8. Conclusion 268

9. Bibliography 286 
To my mother

\section{Sarah Nave Wiggins}




\section{$\underline{\text { Introduction }}$}

The nineteenth century anti-lynching campaign began as a response to the American peculiarity of lynching an overwhelming number of African Americans during the latter part of that century. Although there is a clearly visible record from the early 1880 s of people attempting to expose lynching as a crime in need of swift and stern punishment, the origins of the campaign against lynchings is usually stated to have begun in 1892 with the efforts of African American journalist Ida B. Wells, when she used her editorials to question the motives that were being given for lynching. Wells' activities were certainly a catalyst for the movement and she did play a major role in advancing previous efforts, but the early stages of the movement began a decade prior to her involvement. Moreover, the connection between Americans and Britons, which played a pivotal role in exposing the crime outside of America and in influencing attitudes and actions within America, also began prior to Wells' first visit to Europe in 1893. This study shows that the nineteenth century anti-lynching movement occurred between 1883 and 1900, and that American anti-lynching agitators united with reform minded individuals in the United Kingdom as early as 1883 , ten years prior to what has generally been stated. Therefore, the contention that anti- 
lynching protest originated with the efforts of Ida B. Wells in 1892 and accelerated into an international movement during her visits to England and Scotland in 1893 and 1894, is only a latter part of the story. In this Dissertation, the movement is viewed as having occurred in three phases: Chapter One through Chapter Four is representative of the first phase (18831891); Chapter Five and most of Chapter Six represent the second phase (1892-1894); the latter part of Chapter Six and all of Chapter Seven represent the third phase of the movement (1894-1900). These findings present a more detailed account of the nineteenth century antilynching movement and should complement previous studies.

Journals and periodicals, newspaper articles, correspondence, diaries, membership data and autobiographies show that there were Americans speaking out and organizing in protest of lynchings as early as 1883 . Likewise, that there were concerned Britons assisting in the expose from that date throughout the years of acceleration when Wells toured the United Kingdom, and then for several more years until the English aspect of the movement began to dissolve and its American counterpart became more pronounced.

In American history, the early 1880s mark the end of the Reconstruction era and the beginning of the Gilded Age. Although the time period was 
brief, Reconstruction represented advancement and hope for African

Americans newly emancipated from slavery. Initiated by the close of the

Civil War and the Emancipation Proclamation, blacks and whites witnessed the total abolition of chattel slavery with the Thirteenth Amendment to the United States Constitution in 1865 . Further attempts to more clearly define the spheres of freedom were made by the passage of the Civil Rights Act in 1866, the Fourteenth Amendment in 1868 and the Fifteenth Amendment in 1870, all of which collectively extended citizenship privileges. ${ }^{1}$

The expansion of political rights, allowing black males to vote and seek political office, was fully utilized by a large percentage of the African American constituency. Their active political participation was encouraged by a Republican Party which needed their votes to maintain its dominant status. As a result of this cooperation, two African Americans, Hiram R. Revels and Blanche K. Bruce, were elected to the United States Senate, and a substantial number of black congressmen, state legislators and other local officials became politically endowed as well. ${ }^{2}$

\footnotetext{
${ }^{1}$ For detailed accounts of legislative activity and the evolution of political, economic, and social conditions of African Americans during the Reconstruction era see: Eric Foner, Reconstruction: America's Unfinished Revolution, 1863-1877 (New York: Harper \& Row, 1988); Also see W. E. B. DuBois, Black Reconstruction in America, 1869-1880 (New York: Harcourt, Brace, 1935); John Hope Franklin and Alfred A. Moss, Jr., From Slavery to Freedom: A History of Negro Americans, $6^{\text {th }}$ ed., (New York: McGraw Hill, Inc., 2000); Mary Francis Berry and John Blassingame, The Long Memory: The Black Experience in America (New York: Oxford University Press, 1982).
} 
The pursuit of education, which was assisted by the Freedmen's Bureau, northern missionaries, and literate blacks, became a primary preoccupation for the black community during Reconstruction. Having been forbidden mentally stimulating activities during enslavement, blacks of all ages were anxious to learn. This was indeed the period in which the foundation for free public schooling was laid in many areas of the country. ${ }^{3}$

These political and educational advancements produced a great deal of hope among blacks struggling to establish stable communities. Although the new southern economy evolved to a pitiful expression of capitalism for African Americans, and the possibility of land ownership dwindled as the era declined, those initial successes coupled with an abiding faith in God and the Union led blacks to believe that their circumstances would improve.

The removal of federal troops from southern territory as a condition of the informal "Compromise of 1877 " greatly facilitated the transition from advancement to declination for African Americans. No longer protected by the presence of soldiers who had been stationed in the region since the

\footnotetext{
${ }^{2}$ For background information and political involvement specific to Hiram Revels and Blanche K. Bruce see: Emma Lou Thornbrough, Black Reconstructionists: Great Lives Observed (Englewood Cliffs: Prentiss Hall, 1972); George A. Sewell and Margaret L. Dwight, Mississippi Black History Makers (Jackson: University Press of Mississippi, 1984); Vernon L. Wharton, The Negro in Mississippi (New York: Harper \& Row, 1947).

${ }^{3}$ James D. Anderson, The Education of Blacks in the South, 1860-1935 (Chapel Hill: University of North Carolina, 1988), 4-32.
} 
beginning of Reconstruction, blacks fell prey to forces bent on redeeming the South by firmly reestablishing blacks in subservient relationships to whites. The sharecropping and tenant farming systems prevented economic betterment; funds became less available for black schools, thereby reducing the quality of education; the white community moved quickly toward segregating public accommodations; and individual states began disfranchising blacks through restrictions such as poll taxes, the Grandfather Clause, and literacy tests.

Moreover, the support that African Americans had come to expect from the Republican Party had diminished by the late 1870 s as northern industrialists, who had gained control of the Republican Party, began to "grow weary of the crusade for blacks." Many of them began to "turn to more profitable and practical pursuits," and were anxious to see a quick settlement to the southern problem. ${ }^{4}$ Eric Foner notes in Reconstruction:

America's Unfinished Revolution, 1863-1877, that although:

The humanitarian impulse that had helped create the Republican party ... had not entirely disappeared ... southern issues, however, played a steadily diminishing part in northern Republican politics and support for the idea of federal intervention to enforce the Fourteenth and Fifteenth Amendments continued to wane. ${ }^{5}$

\footnotetext{
${ }^{4}$ Franklin, From Slavery to Freedom, $222 \& 230$.

${ }^{5}$ Foner, Reconstruction, 586.
} 
The removal of Federal troops also coincided with the rise of lawlessness and terror directed at blacks who were considered to be a threat to white supremacy and the evolving system of apartheid. To ensure political, economic, and social hegemony, members of the white community instituted the practice of lynching and mob violence, which served as punishment for those who stepped out of line and as a tactic used to instill fear in others. ${ }^{6}$ The lynching of African Americans escalated toward the end of the Reconstruction era as "lynch law" became an alternative form of dealing with blacks. The practice was not a new phenomenon in America, but prior to emancipation, it was seldom used as the chosen method of punishment for enslaved blacks who were a valued source of free labor. However, during the latter years of the nineteenth century and early twentieth century, African Americans began to represent a greatly disproportionate number of lynching victims. $^{7}$

\section{History of Lynching}

A common definition of lynching is to commit to death without due

\footnotetext{
${ }^{6}$ Franklin, From Slavery to Freedom, 310.

${ }^{7}$ James Elbert Cutler, Lynch-Law: An Investigation Into the History of Lynchings in the United States, (New York: Negro Universities Press, 1905), 135.
} 
process of law, especially by hanging. That is traditionally the way most people have thought of the term, when in fact, the unlawful execution of a person or persons, regardless of the method, has been referred to historically as lynching. Lynching has "always been considered as operating wholly without, or in opposition to established laws of government.",8

The practice of lynching has a definite history, but a vague and disputed origin. There have been similar practices related to deliberate, unlawful punishment resulting in death in certain European regions, but not used as extensively and sanctioned as much by large segments of the population as it has been in America. In America, lynchings were originally equated with whipping and did not always result in fatality. They were connected to what became known as Lynch-Law, again referring to the punishment of suspected persons without the benefit of trial and often administered at the hands of a mob. ${ }^{9}$

It has been suggested by some early writers that the term "Lynch-Law" may have referred to what was first known as "regulation," the practice of unlawful punishment inflicted by a group of men known as "Regulators" during the Revolutionary War period. That those punishments occurred near

\footnotetext{
${ }^{8}$ Ibid., 15.

${ }^{9}$ Frank Shay, Judge Lynch: His First Hundred Years (New York: Ives Washburn, Inc., 1938), 12.
} 
Lynche's Creek in both North and South Carolina is what connects the practice to the term. "The Regulators circumvented the law by attacking people who could be perceived as vying with them for economic and political power and control.",10

The most common reference to lynching is related to the Lynch family of Virginia, the same family of which John Lynch was a member and for whom the town of Lynchburg was named. It was John Lynch's brother, Charles Lynch, and his neighbors who vested themselves with the authority to punish Tories and desperados who harassed them by stealing their horses. In 1780, Lynch illegally fined and imprisoned certain British loyalists, but was exonerated because the act was determined to be "illegal, but justifiable." This determination set a precedent for surrounding areas, and acts of punishment not sanctioned by law, including whipping, taring and feathering, and other humiliating and degrading acts, thereafter became known as "lynch-Law.",

Lynch-Law became a standard form of castigation as westward European expansion and settlement tamed the frontier. As part of this phase of

\footnotetext{
${ }^{10}$ Jacqueline Jones Royster, ed., Southern Horrors and Other Writings: The AntiLynching Campaign of Ida B. Wells, 1892-1900 (Boston: Bedford Books, 1997), 9.

${ }^{11}$ Cutler, Lynch-Law, 30.
} 
American history, referred to as "frontier justice," it was deemed necessary in the absence of established courts and is viewed as having paved the way for the creation of organized legal systems. ${ }^{12}$

There was a definite upsurge in the number of lynchings after 1830 related to the abolitionist movement. As William Lloyd Garrison began to approach the subject of freeing enslaved Africans from a more radical stance, and with the Nat Turner revolt in 1831, slaveholders began to view abolitionists as a major threat. In addition to the tightening of laws to restrict the movement of free blacks and fugitive slaves, there were attacks on abolitionists who attempted to enter the South. Pro-slavery advocates castigated abolitionists for daring to speak out against slavery, a condition that they believed abolitionists knew little about, and blamed them for the necessity of having to resort to lynching. Abolitionists responded that such lawless violence was the direct consequence of slavery. ${ }^{13}$

Although lynchings in America were not racially distinctive in the initial years, there began to be a disproportionate number of African American

\footnotetext{
12 Donald L. Grant, The Anti-Lynching Movement, 1883-1922 (San Francisco: R \& E Research Associates, 1975), 1.

${ }^{13}$ William Lloyd Garrison, Liberator, 10 August 1838. Reprinted in Cutler, Lynch-Law, 106. Also see: Merton L. Dillon's Slavery Attacked: Southern Slaves and Their Allies, 1619-1865 (Baton Rouge: Louisiana State Press, 1990) for further insight into the evolution of abolitionist activity and resultant pro-slavery reactions.
} 
victims near the end of the Reconstruction period and throughout the late nineteenth and early twentieth centuries. Also, the character of lynching became much more torturous and almost always resulted in death. The onset of the practice overwhelmingly directed at African Americans ran counter to the punishment of blacks during the antebellum era. When blacks had the status of property, it made little sense for slaveholders to risk the loss of a valuable commodity. Even in view of a perceived reason to get rid of an enslaved African, it was to the owner's advantage to sell rather than kill the person. After emancipation, however, there ceased to be this type of relationship between blacks and whites, and as the Reconstruction era revealed the possibility of political advantage and equal status for blacks, some whites resorted to Lynch-Law as the means of maintaining control. ${ }^{14}$

A study tying the prevalence of lynching victims to home ownership further validates this premise. "The Associated Press documented 57 violent land takings in an 18 month investigation of black land loss in America."15 They found an overwhelming prevalence of black landowning victims who

\footnotetext{
${ }^{14}$ Ida B. Wells, A Red Record (Chicago: Donohue \& Henneberry, 1895), 1. Reprinted in On Lynchings: Southern Horrors, A Red Record, Mob Rule in New Orleans (Salem: Ayers Company Publishers, 1993).

${ }^{15}$ Delores Barclay, Todd Lewan, and Allen G. Breed, "Torn From the Land: Landownership Meant Death For Many Blacks," Charleston Gazette, 3 December 2001: $1 \mathrm{~A}$
} 
"were attacked by whites who ... wanted to drive them from their property [or] ... wanted the land for themselves." An example was that of Anthony P. Crawford, "one of the most prosperous [African American] farmers in Abbeville County, South Carolina." After being harassed and eventually lynched, much of Crawford's estate ended up in the hands of whites.

Between 1865 and 1965, more than 3,000 lynchings were investigated by Tuskegee Institute and the NAACP, many of which were crimes committed against property owners noted Ray Winbush, director of race relations at Fisk University. "If you are looking for stolen land," he said, "just follow the lynching trail." Thus, acquiring the land of African Americans and assuring that they remained in a non-landholding status was a common motivation for lynchings. ${ }^{16}$ The report documents and gives further validity to what has already been speculated by anti-lynching activists throughout history -- that the primary motivation for lynchings of African Americans in the late nineteenth and early twentieth centuries was to stifle upward mobility, economically, politically, and socially.

The African American journalist Ida B. Wells-Barnett ${ }^{17}$ is usually

\footnotetext{
${ }^{16}$ Ibid. Also see: Leon F. Litwack, "Hellhounds," in Trouble in Mind: Black Southerners in the Age of Jim Crow (New York: Alfred A. Knopf, 1998), 280; and James Allen, Hilton Als, John Lewis, Leon F. Litwack, eds., Without Sanctuary: Lynching Photography in America (San Francisco: Twin Palms Publishers, 2000), 27.
} 
associated with having initiated the first public outcry against lynching atrocities. It was her early treatment of the subject in editorials and lectures which instigated her exile from the South, generated support from the newly developing black women's club movement, and later initiated her antilynching speaking tour in Scotland and England. The impact of the publicity and sympathy that she received in the United Kingdom assisted the formation of an anti-lynching campaign and led to a more appropriate response to lynching in America. ${ }^{18}$

Wells-Barnett's life and her outstanding work investigating and speaking out against lynchings has been well documented in her own publications such as: Crusade For Justice: The Autobiography of Ida B. Wells;

${ }^{17}$ Ida B. Wells will be referred to by her married name, Ida B. Wells-Barnett in references that occur after 1895, the year in which she got married, and when referring to her life in general.

${ }^{18}$ James Elbert Cutler, inspired by the impact of the European anti-lynching campaign wrote Lynch-Law: An Investigation Into the History of Lynchings in the United States (New York: Negro Universities Press, 1905), which approaches the subject of lynchings from a historical perspective while revealing statistics and examining justifications and remedies for the crime. For detailed statistical evidence and commentary on lynchings specific to the late nineteenth century see: Ida B. Wells' A Red Record in On Lynchings (New York: Arno Press and the New York Times, 1969). Frank Shay's Judge Lynch provides historical analysis and state by state comparisons of lynching incidents. More recent studies on lynchings include: Donald Grant's Anti-Lynching Movement, 18831922 (San Francisco: R. E. Research Associates, 1975). Also see: Stewart E. Tolney and E. M. Beck, A Festival of Violence: An Analysis of Southern Lynchings, 1882-1930 (Urbana: University of Illinois Press, 1995), and Litwack, Als, Allen, and Lewis, Without Sanctuary. While the focus of Without Sanctuary is the exhibition of lynching photography, it also includes an excellent "Introduction" and other significant historical commentary on the subject. 
$\underline{\text { Southern Horrors; A Red Record; Mob Rule in New Orleans; The Reason }}$

Why the Colored American is Not in the World's Columbian Exposition,

and a wide variety of essays and articles. ${ }^{19}$ There are also a few biographies

of Wells-Barnett that are quite enlightening on aspects of her life and the

anti-lynching campaign. For example, Mildred I. Thompson's Ida B. Wells-

Barnett: An Exploratory Study of an American Black Woman, 1893-1931

(1990) attempts to provide details of Wells-Barnett's life and experiences

that are not covered in her autobiography or the writings of other historians.

Linda O. McMurry's To Keep the Waters Troubled: The Life of Ida B.

Wells (1998) further defines the historical record of Wells-Barnett, as does

Patricia A. Schechter's recent biography Ida B. Wells-Barnett \& American

Reform, 1880-1930 (2001). The Memphis Diary of Ida B. Wells: An

Intimate Portrait of the Activist as a Young Woman (1995) by Miriam

DeCosta-Willis takes a close look at the early years of Wells-Barnett's life

in Memphis, Tennessee, and compares the diary to others such as Charlotte

Forten's and Alice Dunbar Nelson's. There are also a few shorter and

\footnotetext{
${ }^{19}$ Alfreda Duster, Crusade For Justice: The Autobiography of Ida B. Wells (Chicago: The University of Chicago Press, 1970); Southern Horrors, A Red Record, and Mob Rule In New Orleans, are compiled in Ida B. Wells, On Lynchings (Salem: Ayers Company Publishers, 1993); The Reason Why the Colored American Is Not In the World's Columbian Exposition is included in the Appendix of Mildred Thompson's Ida B. WellsBarnett: An Exploratory Study of an American Black Woman, 1893-1931 (Brooklyn: Carlson Publishing Inc., 1990).
} 
popular biographies, such as Dorothy Sterling's Black Foremothers: Three Lives (1988), that supply general information about Wells-Barnett's life and the anti-lynching campaign. ${ }^{20}$

None of these publications, however, explores the extent of interaction between Europeans and Americans in the anti-lynching effort. Vron Ware's Beyond the Pale: White Women, Racism and History (1992) provides the most complete picture of the European anti-lynching movement outside of Wells-Barnett's autobiography. Her focus, however, is on the feminist aspect of the campaign and the political implications of white women aligning with a black woman (Ida B. Wells) to confront racism and sexism. In addition, Vron Ware's attention to the subject begins with Wells-Barnett's involvement in and solidification of the movement, when clearly there was a significant stirring of effort and trans-Atlantic interaction prior to WellsBarnett's visit to the United Kingdom in $1893 .^{21}$

Although Wells-Barnett was the primary person to bring lynchings in

\footnotetext{
${ }^{20}$ Mildred I. Thompson, Ida B. Wells-Barnett: An Exploratory Study of an American Black Woman, 1893-1931 (Brooklyn: Carlson Publishing Inc., 1990); Linda O. McMurry, To Keep the Waters Troubled: The Life of Ida B. Wells (New York: Oxford University Press, 1998); Patricia A. Shechter, Ida B. Wells-Barnett \& American Reform, 1880-1930 (Chapel Hill: University of North Carolina Press, 2001); Miriam DeCostaWillis, ed. The Memphis Diary of Ida B. Wells (Boston: Beacon Press, 1995); Dorothy Sterling, Black Foremothers: Three Lives (New York: The Feminist Press, 1988).

${ }^{21}$ Vron Ware, Beyond the Pale: White Women, Racism and History (London: Verso, 1992).
} 
America to the forefront of public consciousness, her role was that of catalyst for a nascent anti-lynching movement. She was keenly aware of the acceleration of crimes against blacks in the 1880s but did not become sufficiently suspicious of white motives for them until 1892 when she began to actively investigate lynchings.

The European anti-lynching campaign lasted until approximately 1897. By then, the impact of Wells-Barnett's European trip had been felt in the United States, and protestors in the United Kingdom had served the purpose of motivating more Americans to begin denouncing lynchings. During the period of trans-Atlantic involvement (1883-1897), a number of American and European humanitarians supported each other's efforts to expose American lynchings to the world by speaking out and by writing on the topic in various publications.

Numerous sources document the outspokenness of egalitarians such as T. Thomas Fortune, Frederick Douglass, Francis E. W. Harper, Albion Tourgee, William Lloyd Garrison, Jr., and Ida B. Wells-Barnett in protesting lynchings and other discriminatory acts against African Americans in the late 1800 s. Their appeals for justice were heard by a few people in the United Kingdom such as Catherine Impey, Isabella Fyvie Mayo, Florence Balgarnie, Charles Aked, and Celestine Edwards. In particular, the Quaker 
community and other religious and humanitarian groups became committed to exposing the crime. This group of Americans and Europeans cooperated in an anti-discrimination effort culminating in the anti-lynching campaign that had many parallels to the earlier trans-Atlantic connection in the abolitionist movement.

This study will examine three distinct phases in the international antilynching campaign. The initial phase took place from 1883 to 1891, when the first cooperative efforts related to the post-emancipation struggles of African Americans began to develop between Americans and persons in the United Kingdom. During this period, the African American press and African American leaders first began to speak out in protest of lynchings. It was in the early 1880 s that journalists such as T. Thomas Fortune, orators such as Frederick Douglass, and white writers such as Albion Tourgee and George W. Cable began to oppose this and other developing trends that were meant to stifle African American advancement. It was during this phase that the British reformer Catherine Impey made known her desire to assist American agitators in their anti-discrimination endeavors.

Because it began with the involvement of Ida B. Wells, the second phase of the anti-lynching movement that occurred from 1892 to 1894 is referred to as "the Catalytic Phase." Up to that point the efforts of 
Fortune, Douglass, Tourgee, Impey, and others represented a nascent antilynching movement that obtained the spark it needed from Wells' intervention. This is the period of the movement in which an actual organization was established in the United Kingdom. During this phase, Wells was brought to England to travel the region and speak to religious congregations, the press, and the general public, and as a result supporting organizations began to make resolutions denouncing lynchings.

Phase three, the last to be covered in this study, took place from 1894, when Wells left the United Kingdom, to the end of the nineteenth century. This period represents the final stage of involvement in England and the impact of the English response in America. During this phase, there was an organizational transition in the United Kingdom in which Catherine Impey's influence was superseded by that of Isabella Fyvie Mayo and Celestine Edwards, editor of the new journal, Fraternity. ${ }^{22}$ That transition and trends developing in English society influenced the focus of the organization which led to a decline in its anti-lynching activities. However, in America, significantly more individuals and organizations began to denounce lynchings and seek solutions to the crime.

\footnotetext{
${ }^{22}$ Fraternity was the organ of the Society For the Recognition of the Universal Brotherhood of Man. It was edited initially by Celestine Edwards, who began publication in London July 1893.
} 
In Chapter One, "Catherine Impey: Neo-Abolitionist Extraordinaire," the initial phase of the anti-lynching movement is revealed through Catherine Impey's expressed desire to help African Americans. Her plea to Frederick Douglass, a veteran abolitionist, orator, and statesman who had begun to address lynchings in his speeches in the early 1880 s, was what initiated the trans-Atlantic connection of the anti-lynching movement, which was ten years earlier than most scholars acknowledge Impey's awareness of lynchings.

Chapter Two, "T. Thomas Fortune and the Afro-American League," profiles the efforts of journalist $\mathrm{T}$. Thomas Fortune in the battle against lynchings. Through the agency of his newspapers, and his organization of the Afro-American League, he provided an early awareness of the severity of the problem of lynching and pushed for a solution. Fortune began corresponding with Catherine Impey in the 1880 s and became a consistent supporter and contributor to her anti-discrimination and anti-lynching work in England.

Chapter Three, “Albion Winegar Tourgee: Radical Republican and Civil Rights Advocate," examines the first-hand accounts of Albion Tourgee, a northern humanitarian transplanted in the South during Reconstruction. His experiences motivated him to write about the southern propensity towards 
lynchings and other forms of injustice inflicted on African Americans living in the South. Through his novels, $\underline{\text { A Fool's Errand }}{ }^{23}$ and Bricks Without Straw, ${ }^{24}$ greater awareness was brought to the southern situation. His organization of the Citizen's Equal Rights Association was his innovative approach to its remedy.

Chapter Four, "Anti-Caste," looks at the journal, Anti-Caste, which Catherine Impey began to publish in 1888; it represented the first international expose of lynchings in America. ${ }^{25}$ The profile of that journal is included to illustrate Impey's early awareness of the crime and her interaction with Americans, Britons, Scots, and others on the subject of global oppression in general and African American oppression in particular. The model of Penelope Bullock's "Profile of A Periodical: Voice of the Negro" is used to dissect components of the journal. ${ }^{26}$

Chapter Five, "A Quickening of the Movement: Enter Ida B. Wells,"

\footnotetext{
${ }^{23}$ Albion Tourgee, A Fool's Errand by One of the Fools, John Hope Franklin, ed. (Cambridge: Harvard University Press, 1961).

${ }^{24}$ Albion Tourgee, Bricks Without Straw, Otto Olsen, ed. (Baton Rouge: Louisiana State Press, 1969).

${ }^{25}$ Anti-Caste was edited by Catherine Impey and published at Street, Somersetshire, England between March 1888 and 1895.

${ }^{26}$ Penelope Bullock, "Profile of A Periodical: The Voice of the Negro," The Atlanta Historical Bulletin 13, no. 2 (June 1968). For the reproduction of all fifteen pages of this article see: http//www.peachstar.org/ga_stories/topics/056276p.htm.
} 
reveals the interests and activities of Ida B. Wells during the early phase of the anti-lynching movement in which she was not actively involved. It pinpoints the beginning of her anti-lynching activities in Memphis, Tennessee, which led to her exile from the American South and her resultant interaction with influential persons, particularly Frederick Douglass and African American women in the northeastern United States.

Chapter Six, "Expanding Trans-Atlantic Connections: Ida B. Wells in the United Kingdom," chronicles the initial contact that Ida B. Wells made with Catherine Impey and Isabella Fyvie Mayo in England and Scotland, and presents the sequence of events which pertained to her anti-lynching speaking tour in the United Kingdom in 1893 and 1894. The solidification of the anti-lynching movement in the United Kingdom and its impact on Americans is examined.

In Chapter Seven, "Fraternity," the profile of the English journal Fraternity, brings the interactions and backgrounds of English participants to the surface and identifies the factors which contributed to the decline of the trans-Atlantic movement. In this chapter, the latter phase of the English anti-lynching campaign is verified by articles which appeared in Fraternity from 1893 to 1897 , by newspaper accounts, and by the activities of the Society for the Recognition of the Brotherhood of Man during that time. 
The focus of this study is to examine the actions and interactions of specific individuals and organizations in the United Kingdom and in the United States involved in the effort to abolish lynchings in America during the nineteenth century. It is also to show that the seeds for the movement were sown ten years prior to the time that Wells' trip to the United Kingdom was planned, and that the campaign in the United Kingdom took on a life of its own and lasted for approximately three years beyond Wells' visit. The century culminated with responses in America that were directly related to those earlier trans-Atlantic initiatives. This study addresses an obvious void in the anti-lynching historical record. In addition to redefining the point of origin of the movement, it provides substantially more detail regarding individuals and their interaction in the movement, thereby significantly enhancing this aspect of American history. 


\section{Literature Review}

A review of literature related to this topic -- international responses and connections in the nineteenth century anti-lynching movement, includes research which has been conducted on lynchings and on Ida B. WellsBarnett, whose name is nearly synonymous with anti-lynching protest of that era. The main sources of primary information which supported this thesis were found in the periodicals Anti-Caste and Fraternity. Every issue of these periodicals was examined over the entire course of their publication. While there are ample sources available on Wells-Barnett's life, they are most abundant for the period of her later years. The pool of data related to her earlier years is sufficient, but has unfortunately been reduced due to two fires in the Barnett home, which destroyed a significant portion of WellsBarnett's personal files. The letters from Catherine Impey to Frederick Douglass, usually very lengthy and relating specifically to this subject proved to be extremely valuable. Also, the published writings of T. Thomas Fortune, Frederick Douglass, Albion Tourgee, and Ida B. Wells-Barnett were a major contribution to this work.

Several sources document the lynching phenomenon, in the course of which anti-lynching efforts are usually discussed. Therefore, while not 
specifically addressing the thesis of this study, they have served to provide background information on the incidence of lynchings, the historical eras in which the crimes were perpetrated, and the persons involved in promoting or condemning the crime. These publications usually attempt to define lynchings, pinpoint origins and historical development, and provide detailed accounts and statistical evidence of lynchings. Some of the studies which fall into this category are: Ida B. Wells' A Red Record; James Elbert Cutler's Lynch-Law: An Investigation Into the History of Lynching in the United States; Frank Shay's Judge Lynch: His First Hundred Years; Walter White's Rope and Faggot; and Stewart E. Tolney's and E. M. Beck's A Festival of Violence: An Analysis of Southern Lynchings. ${ }^{27}$

Cutler's book is the "earliest broad study of lynching," and reflects the interest in lynching as it became increasingly more prevalent during the 1890s and early 1900s. As is customary in these studies, Cutler approaches lynching from a historical perspective, examining the social environment which influenced the offense and offering justifications and remedies for

${ }^{27}$ Ida B. Wells, A Red Record in On Lynchings (New York: Arno Press and the New York Times, 1969); James Elbert Cutler, Lynch-Law: An Investigation Into the History of Lynching in the United States (New York: Negro Universities Press, 1905); Frank Shay, Judge Lynch: His First Hundred Years (New York: Ives Washburn, Inc., 1938); Walter White, Rope and Faggot: A Biography of Judge Lynch (New York: Alfred Knopf, 1929); Stewart E. Tolney and E. M. Beck A Festival of Violence: An Analysis of Southern Lynchings, 1882-1930 (Urbana: University of Illinois Press, 1995). 
abolishing it. The time period of Cutler's study, coming on the heels of Ida B. Wells' anti-lynching lectures in the United Kingdom and the publicity that they generated, makes his perspective very significant. Walter White's discourse documents an enormous number of lynchings and emphasizes the economic connection to the crime. Tolney's and Beck's treatise of the subject provides statisical analyses derived from a variety of scenarios and aspects of lynching history for determining contributing factors related to the offense.

The Anti-Lynching Movement, $1883-1932$ by Donald Grant is a chronological account of anti-lynching activity in the United States during the late nineteenth and early twentieth centuries. Grant begins his study in 1883 to coincide with the Supreme Court decision which nullified the Civil Rights Act of 1875. Black leaders, Grant states, took that decision as a sign that they had to begin to look to themselves for reformation. ${ }^{28}$ Grant acknowledges the anti-lynching protests that Frederick Douglass, $\mathrm{T}$. Thomas Fortune, and other editors, ministers, and educated and articulate blacks made during the 1880 s, but does not connect their efforts to the vital

${ }^{28}$ Donald Grant, The Anti-Lynching Movement, 1883-1932 (San Francisco: R. E. Research Associates, 1975), ix. 
role that the English reformer Catherine Impey and her journal Anti-Caste played in this early stage. Also, while Grant notes that Wells turned to earlier protestors for support when she became involved in the movement in 1892, he only briefly addresses her contributions. ${ }^{29}$ He does represent well the role that the African American press, educators, the church, and the National Association for the Advancement of Colored People (NAACP) played in anti-lynching reform efforts, but much of that effort took place during the twentieth century, beyond the scope of this study. This dissertation significantly adds depth and definition to the nineteenth century phase of Grant's anti-lynching history by introducing the contributions of English participants and expanding on the American response during that time.

A recent study conducted by Mary Jane Brown which culminated in the book entitled Eradicating This Evil: Women in the Anti-Lynching Movement focuses on the impact that women made in anti-lynching efforts from 1892 to 1940 . Beginning with the foundation of anti-lynching protest laid by Ida B. Wells, Brown also highlights the contributions made by Mary Church Terrell, female members of the NAACP, and the Association of

${ }^{29}$ Ibid., 16. 
Southern Women for the Prevention of Lynching, led by Jessie Daniel Ames in the 1930s. Brown's study, while acknowledging the important role that American women played in anti-lynching reform efforts, does not emphasize the participation of British and Scottish activists or developments prior to 1892. Whereas Brown's work is gender specific, this study is intended to show a progression by female and male participants from the earliest antilynching efforts in the 1880s throughout the nineteenth century. ${ }^{30}$

The classic literary discourse on Ida B. Wells-Barnett and the antilynching movement is Wells-Barnett's autobiography, Crusade For Justice: The Autobiography of Ida B. Wells, edited by Alfreda Duster and published in 1970. The book details the span of Wells-Barnett's life and provides more data about her anti-lynching lecture tour in the United Kingdom than any other source. However, the inconclusiveness of that narrative is what inspired this study. The publication of the book brought to light WellsBarnett's important contribution to anti-lynching protest which had previously been neglected by historians. The autobiography portrays WellsBarnett as the initator and lone soldier in the fight against lynchings in the 1890s, while the agitation of American and English activists such as

${ }^{30}$ Mary Jane Brown, Eradicating This Evil: Women In the American Anti-Lynching Movement, 1892-1940 (New York: Garland Publishing Company, 2000). 
Catherine Impey, Frederick Douglass, T. Thomas Fortune, and Albion Tourgee in the 1880 s is not revealed. This study connects early antilynching protestations during the 1880 s to Wells-Barnett's contribution in the 1890s, and examines the persistence of the anti-lynching movement in the United Kingdom after Wells-Barnett's departure. However, the information contained in Crusade For Justice related to Wells-Barnett's experience abroad served as a significant springboard for this study. ${ }^{31}$

Mildred Thompson's Ida B. Wells-Barnett: An Exploratory Study of An American Black Woman, 1893-1930 improves upon Wells-Barnett's autobiography. The biography provides greater detail about many aspects of Wells-Barnett's life, accomplishing Thompson's goal of supplying data on the journalist which had not been previously brought to light and rectifying the negligence of ealier historians in regard to WellsBarnett's contributions. ${ }^{32}$ Her treatment of the anti-lynching campaign, as indicated by the dates of the study, began in 1893, just after Wells-Barnett had begun to add her voice to anti-lynching agitation. In summarizing that

${ }^{31}$ Alfreda M. Duster, Crusade For Justice: The Autobiography of Ida B. Wells (Chicago: University of Chicago Press, 1970).

${ }^{32}$ Mildred I. Thompson, Ida B. Wells-Barnett: An Exploratory Study of An American Black Woman, 1893-1930 (Brooklyn: Carlson Publishing Inc., 1990), 5. 
phase of Wells-Barnett's life, Thompson provides some new information but does not emphasize earlier anti-lynching agitation or provide as much detail about the trans-Atlantic connection as is included in this treatment of the subject.

To Keep the Waters Troubled: The Life of Ida B. Wells by Linda O. McMurry is a well written biography of Wells-Barnett which builds on the foundation laid by Wells-Barnett and Thompson. McMurry admits to giving more attention to Wells-Barnett's early years, believing that her "personality and career were rooted in the environment and experiences of her young adulthood," and because of the emphasis that Wells-Barnett had already placed on her later years in the autobiography. ${ }^{33}$ McMurry basically recounts the description of the anti-lynching campaign given by Wells-Barnett, which places her at the genesis of the movement -- contrasting significantly from the thesis of this study.

Ida B. Wells-Barnett \& American Reform, 1880-1930, by Patricia A. Schechter is a solid biography of Wells-Barnett which provides substantially more detail about the intricacies of Wells-Barnett's personal life and her social activism. Because Schechter has focused on the American reform

${ }^{33}$ Linda O. McMurry, To Keep the Waters Troubled: The Life of Ida B. Wells (New York: Oxford University Press, 1998), ix. 
movements with which Wells-Barnett was associated, such as the antilynching movement, the African American women's club movement, community uplift, and the women's suffrage movement -- her study is primarily confined to American initiatives and responses to those movements as related to Wells-Barnett. The biography is unique in that Schechter offers indepth racial and gender analyses respective of WellsBarnett and others associated with her and the era. Schechter does give attention to the significance of British involvement in the anti-lynching campaign as would necessarily be done in a biography of Wells-Barnett, but her treatment of that aspect of the anti-lynching movement is limited. While it is noted that Wells-Barnett "moved to the center of organized resistance to lynching in the $1890 \mathrm{~s}, " 34$ there is no acknowledgment of anti-lynching efforts prior to Wells-Barnett's entrance to the developing movement, nor does Schechter elaborate on the interaction of trans-Atlantic participants in the movement.

The chapter entitled "To Make the Facts Known" in Vron Ware's Beyond The Pale: White Women Racism and History strengthens the account of the

${ }^{34}$ Patricia A. Schecter, Ida B. Wells-Barnett and American Reform (Chapel Hill: University of North Carolina Press, 2001), 1. 
English anti-lynching campaign that Wells-Barnett presented in Crusade For Justice by providing signifcant information on English and Scottish characters and organizations. Ware examines the coming together of WellsBarnett with white female suffragists, temperance organizers, and humanitarians in the English anti-lynching campaign in her attempt to promote understanding of the "links between racism and male dominance." Beyond the Pale was an important source for this study -- providing significant information and leads to other sources, but it was obviously limited in scope considering the brevity of the discourse on the subject. Ware also commonly associated Wells-Barnett with the beginning of antilynching agitation, ignoring earlier protest efforts in America and the connection between Catherine Impey, Frederick Douglass, Albion Tourgee, and others prior to Impey's connection to Wells-Barnett. ${ }^{35}$

Two notable unpublished works on Wells-Barnett, "The Rhetoric of Ida B. Wells: The Genesis of the Anti-Lynch Movement" by Mary Magdalene Boone Hutton and "The Social and Moral Perspectives of Ida B. WellsBarnett as Resources For a Contemporary Afro-Feminist Christian Social Ethic" by Emilie M. Townes, aid in comprehending Wells-Barnett's social

${ }^{35}$ Vron Ware, Beyond the Pale: White Women, Racism and History (London: Verso, 1992). 
justice ethics, which motivated her involvement in anti-lynching and other movements. Hutton acknowledges antecedents to Wells-Barnett's anti-lynching protest, but she gives them minimal attention and does not connect them to the overall movement. ${ }^{36}$

Wells-Barnett's anti-lynching activities have been studied from a variety of perspectives: as an example of African American female leadershp in Dorothy Sterling's Black Foremothers; as a victim of the dual oppression of race and gender in Paula Gidding's When and Where I Enter; $; 3$ and in numerous essays and articles which analyze the rhetoric of Wells-Barnett such as Shirley Logan's "Rhetorical Strategies in Ida B. Wells's $\underline{\text { Southern }}$ Horrors: Lynch Law In All Its Phases." ${ }^{38}$ None of these examples connect the 1880 s anti-lynching efforts to the catalytic phase, which Wells-Barnett represents.

36 See: Mary Magdelene Boon Hutton, "The Rhetoric of Ida B. Wells: The Genesis of the Anti-Lynch Movement" (Ph.D diss., Indiana University, 1975); and Emilie M.

Townes, "The Social and Moral Perspectives of Ida B. Wells-Barnett as Resources For a Contemporary Afro-Feminist Social Ethic" (Ph.D. diss., Northwestern University, 1989).

37 Dorothy Sterling, Black Foremothers: Three Lives (New York: The Feminist Press, 1988); Paula Giddings, When and Where I Enter: The Impact of Black Women On Race and Sex in America (New York: William Morrow and Company, Inc., 1984).

${ }^{38}$ Shirley L. Logan, "Rhetorical Strategies In Ida B. Wells's Southern Horrors: Lynch Law In All Its Phases," in Sage 8, no.1 (Summer 1991): 3-8. 


\section{Bernard Porter's Critics of Empire: British Radical Attitudes to}

Colonialism in African, 1895-1914, represents Porter's indepth study of various groups in Britain which protested or supported British imperialism in Africa. Political and economic ideologies in response to empire are thoroughly explored. The ideals of the "humanitarian lobby" touched on by Porter are observed in his discussion of nineteenth century liberalism, socialism, and radical expressions of, or reactions to those philosophical theories. The impact of technological advancement, sociology, new biological and anthropological theories, and the replacement of romanticist ideals with scientific technique, characterize intellectual currents of the period. Porter notes the misuse and abuse of some of those theories as represented in the ethnocentrism of Herbert Spencer's Social Darwinist interpretations or the unorthodox and racist anthropological studies of Mary Kingsley, both of whom attracted many European and American disciples to their teachings. These multifarious factors characterize Porter's description of "The New Knowledge" of the period and the role that "humanitarians" played in it. ${ }^{39}$

Admittedly, Porter gives limited attention to certain aspects of the

39 Bernard Porter, "The New Knowledge," in Critics of Empire: British Radical Attitudes To Colonialism in Africa, 1895-1914 (London: MacMillan, 1968), 139-155. 
"humanitarian lobby" in his discussion of anti-imperialist sentiment. The names of persons in this study of the anti-lynching movement, who were vital links to the movement, are not mentioned in Critics of Empire. They are represented to some extent by ideology, but the humanitarians who were motivated by strong spiritual and religious convictions to protest imperialism, militarism, lynching and other societal ills, such as Catherine Impey, Rev. Charles Aked, and the Quaker and Unitarian congregations, are not the focus of Porter's discourse. Critics of Empire however, does provide a comprehensive analysis of British reactions to imperialist activities in Africa between 1895 and 1914, which serve as useful information for understanding the final phase of the anti-lynching movement.

The studies mentioned above, as well as others related to lynching and the anti-lynching reform movement, reflect the human urge to comprehend the crime and to recognize the factors which contributed to its demise. As a result of racism, thousands of African Americans were lynched in the nineteenth and twentieth centuries. Attempts to analyze that phenomenon will continue to inspire research on the topic. Thus far, research from the perspective of this study is not in circulation. 
Recognizing antecedent protestors in the initial stages of the nineteenth century anti-lynching movement is appropriate for accurately reporting this important, yet overlooked aspect of American history. Timing has much to do with what is documented in terms of originating dates for events or movements: just as many people believe that Rosa Parks was the first to defy segregated public transportation in the American South, when in fact she was preceded by others whose actions were not publicized or attached to a movement. There is significant data to verify the existence of a developing anti-lynching movement prior to Ida B. Wells' entrance.

In this study, Wells is recognized as the quickening element which transformed the nascent movement into an actuality. Prior protestors, who were assisted in their efforts by English reformer, Catherine Impey and her journal Anti-Caste during the 1880 s, have not been dealt with in previous literature, nor has any of the historigraphy provided a more comprehensive treatise of the British and Scottish anti-lynching campaign than is presented here. 


\section{Research Methodology}

Research for this aspect of the nineteenth century anti-lynching movement began in London, England with the examination of the periodicals Anti-Caste and Fraternity. Those journals formed the basis for this work. Anti-Caste, located at the Friends House Library in London, and published from March 1888 to July 1895, showed that anti-lynching agitators in America had connected with the English reformer Catherine Impey during the 1880s. The journal was replete with articles and letters related to African American oppression written by T. Thomas Fortune, Frederick Douglass, Albion Tourgee, and others. Catherine Impey's early awareness of lynchings in America as well as her convictions was revealed in her monthly editorials. Entrees from Impey's diary also appeared in AntiCaste, although the diary itself has unfortunately been lost.

Fraternity, which was published from 1893 to 1897, provided evidence of the continuance of the movement in the United Kingdom after Ida B. Wells' departure, and verified the persistence of American participants in support of the English and Scottish protestors during the last phase of the movement. Fraternity also contained minutes of meetings of the Society For the Recognition of the Universal Brotherhood of Man, the primary anti-lynching organization in the United Kingdom. Specific issues of Fraternity identified 
participants in the movement, made clear the mission of the organization, and revealed the financial status of the journal. The microfilm of Fraternity is held at the British Library.

Correspondence represented a significant portion of the primary data used to support this thesis. Letters written by Catherine Impey to Frederick Douglass between 1883 and 1889, verified Impey's desire to assist African Americans and origin of the trans-Atlantic connection. Other letters written by Impey, Frederick Douglass, Albion Tourgee, Ida B. Wells, and T. Thomas Fortune, supported the involvement of these people in the movement and the connections between them. Most of the letters were found in the Frederick Douglass collection at the Library of Congress in Washington, D. C., or the Ida B. Wells Papers at the University of Chicago, in Chicago, Illinois.

The Ida B. Wells Papers also contained useful documents related to Ida B. Wells' life in Memphis, Tennessee, such as her Memphis diary and the litigation papers from the Chesapeake and Ohio Railroad suit. There were also Inter-Ocean and other American and English newspaper articles attesting to Wells' anti-lynching activities and club work. Regrettably, a significant portion of Wells-Barnett's personal documents relating to the time period of this study, were destroyed by fire in two separate incidences. 
The published works of Ida B. Wells: the autobiography; the pamphlets, Southern Horrors, A Red Record, Mob Rule in New Orleans, The Reason Why the Colored American is Not in the World's Columbian Exposition; and numerous essays and articles were extremely reliable for comprehending the various aspects of Wells-Barnett's life. Also, the published works of Albion Tourgee, T. Thomas Fortune, Frederick Douglass, and others were equally significant. Amongst those were autobiographies, speeches, editorials, and other written documents, which clarified their views and activities related to lynching.

American, British, and Scottish newspapers were of inestimable value, however, the most significant of those examined were the newspapers edited by T. Thomas Fortune; the New York Globe, the New York Freeman, and the New York Age. They provided a philosophical image of Fortune, as well as evidence of his anti-lynching agitation during the 1880 s and his organization of the Afro-American League. Microfilm of the The Colored American, the New York Times, the Birmingham Daily Gazette, the Edinburgh Evening Gazette, the Manchester Guardian, the Newcastle Leader, and Shafts were also examined.

Important secondary data in the form of biographies of Albion Tourgee, 
Frederick Douglass, T. Thomas Fortune, Ida B. Wells-Barnett and others helped to describe those personages. In addition, specific studies on lynching defined the scope of anti-lynching research, and verified the significance of this work and its relevance to anti-lynching historiography.

These combined primary and secondary sources were analyzed and synthesized to arrive at the thesis and conclusions asserted in this dissertation. This study presents a broader view of the nineteenth century anti-lynching movement by showing that the movement originated in the early 1880 s, with anti-lynching agitators who preceded Ida B. Wells. It also makes it clear that the genesis of the trans-Atlantic connection of the movement also occurred in the early 1880 s, rather than in 1893 as is commonly believed. 


\section{CHAPTER ONE}

\section{Catherine Impey: Neo-Abolitionist Extraordinaire}

The early 1880 s represent the genesis of the nineteenth century antilynching movement and the period in which American efforts to decry lynchings attracted the English protagonist, Catherine Impey. Impey initiated and sustained the English and Scottish expression of the antilynching movement throughout phase one (1883-1891) and most of phase two (1892-1894) of its existence. Her involvement was critical to the transAtlantic connection of anti-lynching agitation. She sought out influential persons in America, indicated her desire to help alleviate African American oppression, and proceeded to provide a vehicle for exposing that oppression beyond American shores. Impey's input in the anti-lynching campaign created an impetus for continued agitation among Americans whose voices were muffled by prevailing falsifications associated with the crime. The role that Impey played in creating a bridge between American neoabolitionists and their counterparts in the United Kingdom was crucial. The earliest stages of her work throughout the decade of the 1880s laid the foundation for the latter most impacting phase of the movement. 
Catherine Impey derived her inspiration from the abolitionist movement:

When the curse of negro slavery lay upon the Southland, when it means danger and even death to agitate against it, and philanthropy was ever busy upon the thousand social evils of the day; when men who were timid or indifferent begged to be let alone - there came from the young man William Lloyd Garrison those grand words that are now engraved upon his monument at Boston: "I am in earnest, I will not equivocate, I will not retreat a single inch, and I will be heard."1

This quotation from Impey's writings and its reference to William Lloyd Garrison exemplifies Impey's perception of her role as editor of Anti-Caste, the journal that she founded and used to expose the global dehumanization of people of color. The journal touched on atrocities in Africa, Central and South America, India, and Australia. However, it had a particular focus on African Americans because, as stated in the very first issue of Anti-Caste, Impey had "a somewhat intimate personal knowledge of its working [colour caste] in America" due to the fact that she had already visited the United States on three occasions and had "enjoyed the friendship and acquaintance of those known as coloured people." Those visits to the homes of the former abolitionist, Frederick Douglass; judge and novelist

${ }^{1}$ Catherine Impey, "To Our Readers," Anti-Caste, 1, no.1 (March 1888): 1. 
Albion Tourgee; Fannie Coppin, president of the Institute of Coloured Youth in Philadelphia; and others had given her insight into the condition and problems facing African Americans in the late 1870s and throughout the 1880 s. $^{2}$

Obviously, Catherine Impey was very much influenced by the alliance between American and English abolitionists of the antislavery era. Being a member of the Quaker religion and residing in Street, one of the largest Quaker communities in southern England, she grew up hearing stories of Quaker involvement in the abolitionist movement. Impey touched on that experience when speaking of the awe that she felt at the prospect of meeting Frederick Douglass, whom she had heard so much about as a child. ${ }^{3}$

Born August 12, 1847 in Street, Somersetshire, England, Impey represented the offspring of English Quaker abolitionists, who by the 1880s had finished the task for which they had joined together -- abolishing slavery in America. However, as Vron Ware states in Beyond the Pale: the networks, both personal and organizational, which had invited and received American abolitionists were

2 Ibid.

${ }^{3}$ Vron Ware, Beyond the Pale: White Women, Racism and History (London: Verso, 1992), 173. 
still very much in existence following the Civil War and many friendships that had resulted were carried on by the younger generations on both sides. ${ }^{4}$

Catherine Impey seems to have had a personality and character that was very sensitive to actions which divided rather than united humanity. Often quoting the Bible in her writings, her appeal was for brotherhood, encouraging people to look beyond skin color to the soul and commonality of humanity. Such religious and spiritual convictions were supported by a personal drive and determination guided by family and previous community experiences..$^{5}$

The daughter of Robert, the owner of a small agricultural equipment business, and Mary Hannah Impey, Catherine had a generous spirit and was drawn toward helping the underprivileged and downtrodden. She is remembered in the Quaker community as one who "involved herself in philanthropic pursuits, being deeply concerned for people living in unfavorable conditions." 6 Although she lived in Street all of her life, Impey traveled extensively in the British Isles and in the United States, her visits often being associated with issues of discrimination as was

\footnotetext{
${ }^{4}$ Ibid.

5 Impey, "To Our Readers," Anti-Caste, 1, no. 1 (March 1888): 1.

${ }^{6}$ Society of Friends "Biographical Listings," The Friend, 64 ( 1924): 19.
} 
emphasized in her obituary:

Her earliest visit to America was in connection with the colour question, which enlisted her warmest sympathy ... she held deep convictions about the rights of both white and coloured people, and among her natural gifts was an especial charm for young people ... and the elderly ... she made friends the world over ... and her life was spent being a blessing to others ... she lived her religion -- it was not part of her life, but the whole of it. ${ }^{7}$

Impey's Christian religious doctrine included a philosphy that encompassed equalitarian ideals, an end to militarism, a respect for the environment, and the humane treatment of animals. She was also a strict vegetarian and occasionally wrote articles on the subject for the London Vegetarian Society, which appeared in their journal Atonement.

In the late nineteenth century, a non-meat eating philosophy became an advocation of a significant number of social and religious reformers in London, who "identified vegetarianism with spirituality and the Christian gospel." These reformers "argued that simplicity and purity of life, including wholesome food, was the foundation of righteousness." 8 The vegetarian movement was in full swing in 1888 when the young Indian

${ }^{7}$ Ibid.

8 James D. Hunt, Gandhi in London (New Delhi: Promilla \& Company Publishers, 1978), 22. 
nationalist Mohandas K. Gandhi was in London as a law student. One of his deep concerns when arriving in London was his ability to continue following that aspect of his cultural heritage. He complained often of surviving on bread and fruit until he discovered vegetarian restaurants (there were more than ten) owned and operated by members of the London Vegetarian Society. ${ }^{9}$

Members of the movement became a life line for Gandhi, making it possible for him to meet his nutritional needs, supplying him with supporting literature and friendship, and providing a conducive environment for living in adherence to his beliefs. The movement was supported by such prominent people as Arnold F. Hills, a wealthy industrialist and chairman of the Thames Iron Works, who provided the Vegetarian Society with financial assistance and organizational leadership. In January 1893, the London Vegetarian Society re-elected Hills president of the organization. His acceptance speech emphasized his commitment to maintaining the Society's "position as one of the most energetic in London and the vegetarian world." ${ }^{10}$ Henry Salt, author of A Plea For Vegetarianism and a biography

\footnotetext{
${ }^{9}$ Ibid., 20-30.

${ }^{10}$ Margaret Shurmer Sibthorp, "Vegetarianism," Shafts: A Paper For Women \& The
} 
of Henry David Thoreau, was also a proponent of the movement. ${ }^{11}$ It is very possible that Catherine Impey and Gandhi became aquaintances or even friends during his stay in London and his involvement with the circle of friends with whom she was obviously associated. Gandhi, of course, at that time had not yet become a recognizable international figure.

Catherine Impey also protested alcohol trafficking by supporting the Temperance movement. One example of her articles, titled "What Shall We Do With Our Apples?," appeared in Atonement, the organ for The Vegetarian Society, in $1892 .{ }^{12}$ The article was evidently inspired by her involvement in the temperance movement. At first glance, the article, written in the form of a short story, gives the impression of advocating healthful living by eating apples, which it does to an extent, but further reading reveals a story admonishing the use of fermented apples for the production of apple cider -- over fermentation being used for the production of alcohol. The purpose was to encourage farmers to eat and sell whole apples rather than make apple cider. The bruised apples usually used

Working Classes 2, no. 11 (28 January 1893): 205.

${ }^{11}$ Hunt, Gandhi in London, 22.

${ }^{12}$ A. F. Hills, Atonement (London: London Vegetarian Society, 1892), 1- 4. Obtainable from the British Library in London. 
for cider, Impey suggested, should be given to farm animals who would also benefit from healthy produce. ${ }^{13}$ Impey addressed all of the above mentioned issues periodically in journals such as The Village Album, a collection of essays and correspondences kept by the Quaker community in Street. ${ }^{14}$

When Robert Impey, Catherine's father, died at age thirty-eight, Catherine was given the option of taking over and maintaining the family business. She relinquished that opportunity to her sister, Nellie, preferring to stay involved in the "social reform work" that she had begun. ${ }^{15}$ That her economic status was secure enough to take such a position is indicated by a letter written to her friend, Frederick Chesson, in which she stated that she was:

very glad not to be obliged to work for my living, but it is a more serious matter than it seems to some - to deliberately choose a life of independence. ${ }^{16}$

The social reform work which Impey was motivated to perform

13 Ibid.

${ }^{14}$ Ware, Beyond the Pale, 187.

15 Ibid., 186.

${ }^{16}$ Catherine Impey to Frederick Chesson,1886, Rhodes House Library, Oxford (Ref: ci38/163-74). Chesson was secretary of the Aborigines Protection Society when this letter was written. His life was commemorated in the May 1888 issue of Anti-Caste after his death earlier that year. 
materialized into two distinct expressions related to the exposition of crimes and injustices perpetrated against people of color. Those two expressions were the Anti-Caste journal and the establishment of the Society for the Recognition of the Universal Brotherhood of Man (SRUBM). Each played a vital role in the anti-lynching campaign which would become a primary focus for Impey and her close group of associates. ${ }^{17}$

The early international dimension of the movement was motivated by Impey's trip to America in 1878 and her observation of the oppression of blacks as well as her interaction with key people who were already actively protesting lynchings and other forms of discrimination against African Americans. That experience instilled in her a desire to reach out and initiate an alliance between Americans and Britons in a manner similar to the alliance formed by abolitionists. She believed that if the atrocities in America were exposed in England, that would have a positive impact in America. ${ }^{18}$

To this end, she wrote Frederick Douglass a lengthy letter in 1883 expressing her desire "to be of more use to coloured Americans." She

\footnotetext{
17 Ware, Beyond The Pale, 186.

18 Catherine Impey, "The Editor's Annual Address," Anti-Caste, 7 (March 1895): 1.
} 
informed Douglass that her interest in aiding African Americans had been inspired during a previous visit to America as a representative of the Grand Lodge of England's Order of Good Templars, a Temperance organization that held its international conference in Boston ca.1879. ${ }^{19}$

While attending the conference, Impey stayed at the home of Mr. and Mrs. William Wells Brown, noted author and former abolitionist. Brown had been a guest at Impey's father's home many years prior (probably during the 1850s when he was on the abolitionist touring circuit and when his daughter was being educated in England), and Brown was glad to return the favor to the Impey family. ${ }^{20}$ Having traveled throughout Europe, Brown noted that "nothing enhanced his view of the British so much as to be accepted, admired, and feted by the first families of the realm."21

Catherine Impey and several other members of the Order of Good Templars had taken a stand against the organization's attempt to establish separate chapters for black and white members. Having some regret over the method of protest that they used and the outcome, Impey recounted the

${ }^{19}$ Catherine Impey to Frederick Douglass, 15 February 1883, Douglass Collection, General Correspondence R3 V5 Fr 689-697, Manuscript Division, Library of Congress.

20 Ibid.

21 William Wells Brown, The American Fugitive in Europe: Sketches of Places and People Abroad (New York: Negro Universities Press, 1969), 104. 
experience to Douglass:

Some of us had been so simple minded as to say we would rather turn out of the order ourselves than allow any separate system of Lodges to be organized for our coloured brothers and sisters. We were young and enthusiastic and determined to keep true to our principles of fraternity -- and so we got turned out (or we withdrew) from the rest of the order. We English -- and a few true Americans -- and a good many representatives of other lands (Australia, Scotland, and Nova Scotia, etc.) and brought for ourselves a never ending flood of abuse and slander and persecution. ${ }^{22}$

On April 20, 1887, T. Thomas Fortune wrote a letter to Impey applauding her group's past action with the Order of Good Templars. His letter, was in response to one she had written him the previous month, in which two copies of an article explaining the protest were enclosed. Fortune readily agreed with the position taken by Impey and the others and ventured to say that he did not "think the English fully understood how ramifying and intense caste prejudice" was in America. "None there" he asserted, "has given the matter the same thought and investigation that you have."23

Fortune also revealed that he had once been a member of the Order of Good Templars but found the "caste business cropping up so many

22 Impey to Douglass, 15 February 1883.

23 T. Thomas Fortune to Catherine Impey, 20 April 1887, reprinted under "American Color Prejudice" in the New York Freeman, 28 May 1887. 
unexpected places" that he terminated his membership. ${ }^{24} \mathrm{He}$

also expounded on the expense required to:

sustain common and private schools and religious temperance work, because perforce black and white cannot be permitted to mix; double agencies must be employed, necessitating double expense as a matter of course. ${ }^{25}$

The issue of segregation among temperance organizations was significant, considering the number of African Amerians who had been actively involved in temperance work since the antebellum era. Both Martin R. Delany and Frederick Douglass, for example, believed intemperance to be a hindrance to individual success and often spoke in support of the temperance movement. Douglass, as Fortune and Impey, was also "critical of the fact that many of the organized [temperance] societies were cool to Negro membership."26

The indifference of temperance workers toward African American concerns, especially protests of lynchings and segregation, also became a hot issue while Ida B. Wells was in England in 1893 and 1894. The

\footnotetext{
${ }^{24}$ Ibid.

25 Ibid.

${ }^{26}$ Philip S. Foner, Frederick Douglass: A Biography (New York: Citadel Press, 1969), 101.
} 
British were curious about the response of churches and humanitarian organizations in America to lynchings. As Francis Willard, head of the Women's Christian Temperance Union, was in England at the time of Wells' visit, the question of the response of the Temperance movement to lynchings arose. It was at that time that Wells recounted a statement that Willard had made as part of an interview in the October 1890 issue of the New York Voice, which "practically condoned lynchings." Wells noted that in addition to Willard's failure to publicly condemn lynchings, her interview seemed to show sympathy toward southern whites who had to deal with "gross African American practices" which, in her opinion, provoked lynchings. Wells produced a copy of the interview to substantiate her accusations against Willard. Her criticism and Willard's defense of her actions created such a controversy in the temperance movement that the English branch was moved to draft a resolution denouncing lynchings. ${ }^{27}$ Wells' character was called into question by those who doubted her accusation of Willard. Albion Tourgee, however, defended her actions. A letter that she wrote to him shortly after the altercation with Willard reveals

\footnotetext{
27 "Ida B. Wells Abroad - Attitude of Moody and Willard to the Negroes - Description of England's Big Ditch," Chicago Inter-Ocean 9 April 1894, Ida B. Wells Papers, Special Collections, Reggenstein Library, University of Chicago. Also see Duster, Crusade For Justice: The Autobiography of Ida B. Wells; Vron Ware, Beyond the Pale: White Women, Racism and History, and most biographies of Wells-Barnett for an account of this incident.
} 
her gratitude:

I have read your strong words in defense of me and the cause. And as always, I feel grateful to you for the only unequivocal expression in behalf of justice, which you alone seemed moved to make. ${ }^{28}$

While in Boston, Catherine Impey also had spent three days at the home of William Lloyd Garrison, Jr. Garrison had been in England around the time of the confrontation with the Order of Good Templars and its dissident members. In a show of support, he publicly defended the protestor's action, which made him the focus of "scrutiny and repeated interviews."29 When Impey and her friends attended the international convention, Garrison went out of his way to entertain them. Impey was so impressed with his attempt to soothe their wounds that she shared the experience with Douglass and noted:

By way of expressing his sympathy, he [Garrison] would have us spend whole days with him driving us around the city and entertaining little parties of us in his home at Roxbury. ${ }^{30}$

Impey and her associates immensely enjoyed the special attention and the

\footnotetext{
28 Ida B. Wells to Albion Tourgee, 24 November 1894, Ida B. Wells Papers, Special Collections, Reggenstein Library, University of Chicago.

${ }^{29}$ Impey to Douglass, 15 February 1883.

30 Ibid.
} 
privilege of having an insider's view of Boston, as well as the younger Garrison's interpretation of difficulties plaguing African Americans in that post-Reconstruction period. During that visit to America, Catherine Impey became significantly more aware of oppressive conditions in the African American community.

Motivated to become involved, Impey and her friends constructed a plan to approach African American leaders and leaders of the Quaker community before returning to England to see what could be done to remove the "dreadful and foolish prejudices." Whatever attempts they made in that direction failed to be fruitful, and considering the brevity of their time in America, it was concluded that the continuation of their efforts must come from England. ${ }^{31}$

When Impey returned home, she wrote an article in the Quaker journal The Friend, describing the American tour and the discrimination she had seen. That article "brought several expressions of sympathy from the old workers in the anti-slavery cause." 32 To Impey, it was quite simple. Inform English society of American discriminatory practices in general and

31 Ibid.

32 Ibid. 
their much exaggerated expressions in the American South, and once informed, steps to address those practices would automatically follow. Her rationalization is summarized in the following statement:

If English people knew one hundreth part of what I have learned by reading the New York Globe, Christian Register, and by correspondence and personal conversation with coloured persons visiting England, Americans would be stung into activity by the indignation that England would give voice to. ${ }^{33}$

Given that English and American cooperation had been a precursor to civil actions regarding the abolition of slavery in America, it was not unrealistic for Catherine Impey to hold a similar vision for an alliance during this postemancipation period.

Following the initial expose of the situation to English Quakers, the plan included diffusing information about the status of blacks in America, an appeal to churches, and a move to encourage a "deputation of coloured Americans to attend the yearly meeting of Friends." If present, they could present their own case, which Impey felt was sure to create among Quakers a desire to assist their cause. ${ }^{34}$

True to character, Frederick Douglass, who had moved directly from

33 Ibid.

34 Ibid. 
abolitionism to the role of agitator against race and gender discrimination, responded favorably to Catherine Impey's plea and supported her efforts to bring the American problem to the attention of English society. Throughout the decade of the 1880s, Impey corresponded regularly with Douglass, and when her vision manifested into the Anti-Caste journal, Douglass became a consistent subscriber and frequently sent words of encouragement and occasional articles. ${ }^{35}$

A brief glance at many of Douglass' speeches reveal a belief in the ability of the American government to uphold its Constitutional laws and ideals. Often emphasizing the principles of liberty as spelled out for the common good by the Founding Fathers, Douglass embraced the image of a more perfect union and used it to encourage the enforcement of those principles in the American society of his era. ${ }^{36}$ When the Reconstruction period ended, African Americans in the deep South began seriously considering alternatives to the vicious economic cycle of sharecropping and tenant farming and envisoned a bleak picture of political and social equity

\footnotetext{
35 Impey, Anti-Caste, London, (1888-1895). An examination of Anti-Caste, reveals Douglass' support for the journal.

36 John Blassingame and John R. McKivigan, eds. The Frederick Douglass Papers: Series One; Speeches, Debates, and Interviews. Vol. 5, 1881-1895 (New Haven: Yale University Press, 1992).
} 
on the horizon. Groups that were inclined to emigrate from the South found that Douglass did not support that option. ${ }^{37}$

In 1879, Douglass encouraged the "Kansas exodusters" to stay and fight for their rights and build on what they had in the South. He believed that at that stage of economic recovery in the South, white planters needed black labor and could be forced into interacting fairly in the existing agrarian partnership. He "reminded [them] that the way of an oppressed people from bondage to freedom is never smooth." 38 The Constitution, he stated:

was pledged to secure the rights of the Negro, and the American people would get behind the Constitution unless the Negroes themselves, by mass migration confessed that on the soil of the South, the United States Constitution cannot be enforced. 39

Then again, in 1883, at the National Colored Convention in Louisville, Kentucky, where Douglass was attacked for failing to criticize the diminishing support of the Republican party, he acknowledged that "he had no illusions about the Republican party," and reiterated his faith in the ideals of the republic:

${ }^{37}$ Nell Painter, Exodusters: Black Migration To Kansas After Reconstruction. (New York: Alfred A. Knopf, 1976), 16.

38 Foner, Frederick Douglass, 328.

39 Ibid. 
Happily for us the honor of the republic, the United States Constitution is just, liberal and friendly. The amendments to that instrument, adopted in the trying times of reconstruction of the southern states, are a credit to the courage and statesmanship of the leading men of that crisis. These amendments establish freedom and abolish all unfair and invidious discrimination against citizens on account of race and color, so far as law can do so. ${ }^{40}$

In his book entitled, The Anti-lynching Movement, Donald Grant states that "Douglass threw his influence" behind the call for the 1883 "National Colored Convention." The call led, he said:

to an increase in organizing activities by blacks in several states. Texas, South Carolina, and Arkansas held state conventions which recognized the importance of the lynching problems. ... The Arkansas group met in Little Rock ... and passed a resolution calling for the punishment of lynchers. At Louisville 300 delegates from twenty-seven states heard Douglass denounce lynch law. The practice of placing lynching high on the agenda became routine for practically all Black civil rights meetings during the next forty years. ${ }^{41}$

There were times, however, when Douglass' faith in the Constitution was shaken, such as in 1883, when the Civil Rights Act of 1875 was deemed unconstitutional. He especially began to wonder about the workability of the Constitution after a trip to South Carolina and Georgia in 1888. The suffering and degradation there brought Douglass to the

40 Blassingame and McKivigan, The Frederick Douglass Papers, 91.

41 Donald Grant, The Anti-Lynching Movement, 1883 - 1922 (San Francisco: R \& E Research Associates, 1975), 20. 
realization of "how little he had known about the true condition of his people in the South," and as a result he "began to modify many of the arguments" that he had previously raised. ${ }^{42}$

As with most African American agitators of the late nineteenth century, Douglass addressed all of the issues that concerned the African American community. With blanket inequality, attention to any particular injustice was akin to addressing them all. Although Douglass did not always lend his influence and support to every action and decision of the race, he did consistently speak about the post-Reconstruction challenges of African Americans. He was extremely concerned with disintegrating political opportunities, the evolving system of segregation, inadequate education, and economic exploitation. ${ }^{43}$ However, "of all the suffering and hardships of the Negro people ... the alarming increase in the bestial practice of lynching disturbed Douglass most deeply."44 When Douglass met Ida B. Wells at the beginning of her anti-lynching involvement in 1892, he had already contributed more than a decade to protesting the crime. ${ }^{45}$

\footnotetext{
42 Foner, Frederick Douglass, 331.

43 Blassingame and McKivigan, The Frederick Douglass Papers. An examination of Douglass' speeches reveals his concern for these issues.

${ }^{44}$ Foner, Frederick Douglass, 361.
} 
Douglass' stance on lynchings was clear. He often protested the crime in

his orations as he had at the 1883 National Colored Convention when

explaining the need for such a convention. He spoke of the propensity of

Southern whites to take the law into their own hands by proceeding:

to whip, stab, shoot, hang or burn the alleged culprit, without intervention of courts, counsel, judges, juries or witnesses. In such cases it is not the business of accusers to prove guilt, but it is for the accused to prove innocence, a thing hard for any man to do, even in a court of law, and utterly impossible for him to do in these infernal Lynch courts. A man accused, frightened and captured by a motley crowd, dragged with a rope about his neck in midnight darkness to the nearest tree, and told in coarsest terms of profanity to prepare for death, would be more than human if he did not, in his terror-stricken appearance, more confirm suspicion of guilt than the contrary. ... There are occasional cases in which white men are lynched, but one sparrow does not make a summer. Every one knows that what is called Lynch law is peculiarly the law for colored people and for nobody else. If there were no other grievances than this horrible and barbarous Lynch law custom we should be justified in assembling as we have now done to expose and denounce it. ${ }^{46}$

Although the convention failed in its main purpose of influencing the Republican party to defend the rights of blacks, it did lead to an increase in organizational efforts in some southern states, which held state conventions

\footnotetext{
45 See Crusade For Justice: The Autobiography of Ida B. Wells, and publications on Douglass' speeches such as Blassingame's and McKivigan's The Frederick Douglass Papers, and Philip Foner's Frederick Douglass: A Biography, for Douglass' speeches which protest lynchings before 1892 .

46 Blassingame and McKivigan, Frederick Douglass Papers, 93.
} 
to address the frequent occurrences of lynchings. ${ }^{47}$

On April 16, 1886, as a third-time annual speaker for the 24th celebration of emancipation in the District of Columbia, Douglass acknowledged the return of Federal governmental control to the Democrats and encouraged a wait-and-see attitude concerning that administration's accomplishments. He touched on African American achievements since emancipation, but emphasized still-existing problems. As to lynching, he lamented "as far as the colored people of the country are concerned ... lynch law, violence, and murder have gone on about the same as formerly and without the least show of federal interference or popular rebuke."48

When lynchings increased dramatically in the 1890s, Douglass was compelled to address the issue more forcefully. Historian William L. Andrews notes that Douglass, inspired by the initiatives of Ida B. Wells, "went on the offensive not only against lynchings but against those North and South, who palliated it." In July 1892, his article "Lynch Law in the South" appeared in the North American Review, and during 1892 and 1893, Douglass frequently delivered the anti-lynching / anti-discrimination

\footnotetext{
47 Grant, The Anti-Lynching Movement, 20.

48 Blassingame and McKivigan, The Frederick Douglass Papers, 215.
} 
speech entitled, "The Lessons of the Hour," which was published as a pamphlet in 1894.49

In "The Lessons of the Hour," Douglass asserted that African Americans were living in the most perilous times since emancipation, amidst accusations that seriously blighted their existence and advancement. He assailed the "Christian country and highly civilized nation" that America was supposed to represent, for perpetrating crimes which had not been surpassed even "in the history of savages." Douglass went on to point out that the charges of abuse and rape against white women were inconsistent with the past actions of blacks those moral character had been demonstrated throughout their existence in America. He provided several examples of this, but noted particularly the period of the Civil War, when southern blacks, entrusted with the care of white women and children in the absence of their enlisted men, committed no such crimes. ${ }^{50}$

When Catherine Impey realized that Frederick Douglass and his second wife Helen would visit London while vacationing in Europe in 1887, she

49 William L. Andrews, ed., The Oxford Frederick Douglass Reader (Oxford: Oxford University Press, 1996), 339.

${ }^{50}$ Ibid., 341. 
wrote Douglass a letter, in which she expressed her eagerness to discuss plans for helping African Americans. Intimating that there was much to talk about, she asked Douglass to "reserve some of the time at Street for a visit to my mother, sister, and self at our home among the fields." 51 She assured Douglass that she would not overtax him or monopolize his time, and cautioned him to "be prepared for [her] most unceremonious household."52 Being on the eve of launching Anti-Caste, it is very likely that Impey was in the planning phase of the journal. There is a reference to Douglass having visited Street in a letter that Impey wrote to him on April 13, 1889, but she did not elaborate on the details of the visit. ${ }^{53}$

In September 1892, Impey had a week long visit with Douglass in Washington, D. C. It was probably her lengthiest stay at his home before he died in 1895. She arrived at Cedar Hill on September 14, after having spent several days at the home of Judge and Mrs. Albion Tourgee. When she arrived at Cedar Hill, she found that Douglass was away at the Colored People's State Fair in Richmond, Virginia, and had not yet received the

51 Catherine Impey to Frederick Douglass, 9 July 1887, Douglass Collection, General Correspondence R4 V6 Fr 588R-5902, Manuscript Division, Library of Congress.

52 Ibid.

53 Catherine Impey to Frederick Douglass, 13 April 1889, Douglass Collection, General Correspondence R5 V7 Fr 322-327, Manuscript Division, Library of Congress. 
telegram of her arrival, but she was made welcome and comfortable by Mrs. Douglass, her sister, Miss Pitts, and the servants. ${ }^{54}$

While waiting for Douglass to return, Impey, Mrs. Douglass, Miss Pitts, two of Douglass' granddaughters, Anna and Estelle Sprague, and two other female visitors to the estate kept each other company. Impey noted that the group was "an interesting mixed family, as to colour." She awoke the following morning to find that Douglass had returned during the night. Her diary entry for that day revealed that she perceived him to be "a grand majestic figure [with] fine features [and] a crown of white hair like the Egyptian monarchs of old." 55

Quite impressed with Douglass' home and the wooded environment in which it was situated, the artistically inclined Impey spent much of her time sketching what to her senses were beautiful surroundings which she recorded, often in a poetical manner in her diary. Douglass' Cedar Hill was located in Anacostia, "a suburban village [of Washington, D. C. ] lying across the broad Potomac River, a few miles to the Southwest of the

54 From the diary of Catherine Impey, September 14, 1892 entry, reprinted in Anti-Caste, 7 (April \& May, 1894): 14-16.

55 Ibid., 15. 
city."56 Impey noted that "trees grew all around," and that there was "a fir grove, with oaks and chestnuts, and grass under foot ... [and] tulip trees." She was particularly struck by the magnificence of "the scene from the veranda, where hammocks and rockers and garden seats, tempt one to rest." 57 Being very meticulous in her descriptions, Impey included the "drive" which was "cut in a spiral fashion around the knoll" with "a glen or valley on each side of the house, down the side of which sloped the vegetable gardens," a source of pride to Douglass, where he pointed out:

The sweet potato plants growing like cucumber vines in a tangle over the ground, among an orchard of young pear trees, \&c. . . . Rising behind the garden to the West is a cornfield 'Indian corn' as we call it in England - where the huge sheaves stand 8 feet high baking in the sun. ${ }^{58}$

Although Douglass was tired from his trip, he made time to visit with Impey. They talked quietly while she sketched, or they strolled as Douglass gave a guided tour of the estate, pointing out sights such as "his odd little den ... a small brick room out in the hot sunshine, where he sometimes hides to be quiet and write."59

56 Ibid.

57 Ibid.

58 Ibid.

59 Ibid. 
By afternoon, the small group of female visitors to the Douglass home had increased in number to six. The original four had been joined by "a Mrs. Lee, a skilled musician and singer, and her daughter. All of them later accompanied Douglass to an art gallery near the White House, where he pointed out some of his favorite pictures. He was particularly fond of two paintings, "The Helping Hand," a picture of "a merry, happy little child helping an old sailor grandfather to row the boat." The other was "a sympathetically drawn household scene in a negro cabin," in which Impey noticed, was an "entire absence of the element of ridicule or caricature, so usual in American pictures of negro life." That evening, Douglass entertained the women by playing the violin while his granddaughter Annie accompanied him on the piano. ${ }^{60}$

On Friday, September 16, Impey stayed at Cedar Hill while the rest of the women went on a day-long excursion. She used that time to finish her sketch and stroll and talk more with Douglass. Their conversation touched on the historical significance of their surroundings as well as personal and family concerns. When they tired of talking, Impey read aloud from a pamphlet that Douglass had on ancient Ethiopian and Egyptian

${ }^{60}$ Ibid. 
civilizations. The diarist noted that in his aging years, Douglass appreciated being read to, a welcome respite from the numerous correspondences and articles of required reading usually awaiting his attention. ${ }^{61}$

The spiritual side of Douglass' disposition shone through when at the end of their stroll, and just before lunch, he suggested that they "be silent awhile and listen to nature." Together, they heard "the gentle falling of dried leaves and small chirp of distant grasshoppers" which felt to Impey "like a prayer" that may have been "a blessed and useful preparation for the future conflict."62

Other features of Impey's visit to Frederick Douglass' home centered around her getting in touch with a friend with whom she had corresponded but not met in person, discussions of Albion Tourgee's Citizen's Equal Rights Association, a tour of an African American community, and an afternoon spent with Joseph Douglass, grandson of the orator. A highlight of that week-long experience was the Sunday visit to a local Presbyterian church. Impey considered it a privilege and relished the opportunity of having an inside look at this aspect of African American culture. Her

\footnotetext{
61 Ibid., 16.

62 Ibid., 15.
} 
comparison of the religious experience to what she was accustomed was noted as follows:

To my English Quaker eyes, the place was luxuriously upholstered. It had long coloured lancet windows, crimson Brussels carpet and cushioned seats through out; an amphitheatre in form and arrangement. The audience of about 700 persons were apparently all "coloured" except four of our party; some fair complexioned, some plain, and a few even to our eyes ugly, but many magnificently handsome, with their wondrous soft black eyes. ${ }^{63}$

At the close of the Sunday service, the Douglass' invited the minister and his wife, Dr. and Mrs. Grimke to their home for lunch. This proved to be quite a pleasant afternoon for Impey, as she listened to interesting and informative talk about "caste" related problems between Douglass and the Grimkes. The hot topic, Tourgee's Citizen's Equal Right's Association, was again discussed, the Grimkes acknowledging their approval of that effort to ease the conditions of blacks and revealing that they had been in touch with Tourgee concerning the formation of the Association. As the afternoon drew to a close, Douglass recaptured some "incidents of the old anti-slavery struggles" and also said "some strong things too, against caste." By the day's end, forty-five visitors had graced the Douglass home, apparently a common

${ }^{63}$ Ibid. 
Sunday afternoon occurrence. ${ }^{64}$

Historian and author John David Smith applied the term "neoabolitionist" to American whites who, after emancipation, argued that slavery was the cause of the contemporary ills plaguing African Americans. Neo-abolitionists believed that the socio-economic and political problems confronting African Americans were directly related to their experiences during enslavement. Although a radical and unaccepted view at the time, it has been verified and validated since. The prevailing pro-slavery attitude of the era was voiciferously challenged by Caroline H. Pemberton, a novelist and descendant of Quakers in Philadelphia; William Goodell Frost, president of the integrated Berea College; authors Albion Tourgee, George Washington Cable, and other late nineteenth century neo-abolitionists in America. ${ }^{65}$ The term is also quite appropriate for the anti-lynching crusaders, many of whom saw themselves as picking up where the antislavery activists left off. Indeed, they perceived the late nineteenth century oppression of African Americans as being akin to enslavement and viewed their protests and outspokeness as leading to a remedy.

64 Ibid.

65 John David Smith, An Old Creed For the New South (Athens: University of Georgia Press, 1985), 85. 
Catherine Impey epitomized and completely captured the spirit of abolitionism. Her Quaker and humanitarian convictions imbued her with the vision of a non-racist society which she was compelled to pursue. Spurred on by her upbringing, her knowledge of the English role in the antislavery crusade, by encouragement from relatives and friends, by being economically stable enough to devote time and energy to such a cause, and by the belief that her actions could and would make a difference, she became the initiator of the international connection in the anti-lynching campaign. ${ }^{66}$

Having visited America at the end of Reconstruction and the beginning of forced restrictions on advancements that had been made during the Reconstruction period, she had a peripheral view of African American challenges. Seeking out Frederick Douglass' advice in terms of how she and others in the United Kingdom could be of assistance led to the publication of her journal Anti-Caste, the primary organ for disseminating information of lynchings in America beyond American shores.

As a central figure in the nineteenth century anti-lynching campaign, Catherine Impey was motivated by examples of "preventable human misery" to implement the teachings of her religion through philanthropy and

66 Ware, Beyond the Pale, 182-190. 
activism. Presuming that reform movements originated on an individual level and that there was "power in individual right action," she intended to exemplify the principles that she advocated. Through her deeds and writings, she expected to encourage others to "withdraw and abstain from actions that upheld caste systems." She frequently referred to biblical scripture to emphasize the unjust character of racism and believed that "all arbitrary distinctions based on differences of social rank, [were] contrary to the mind of Christ." 67

Impey was repulsed by the horrendous act of lynchings, but as terrible as the crime was, her attempt to abolish it was based on her desire to strike a blow at the cause of lynchings, which in her opinion was "colour caste." She believed that Lynch-Law was a manifestation of "the distemper" and that abolishing it alone "would not destroy but cauterise the disease." 68 Impey was deeply concerned about the global oppression of people of color and the audacity of whites to claim dominance over another "member of the human family." However, of all oppression, she considered the American variety to be "the most grinding, the most terrible, the foulest of all we

\footnotetext{
67 Catherine Impey, "To Our Readers," Anti-Caste, 1 (March 1888): 1.

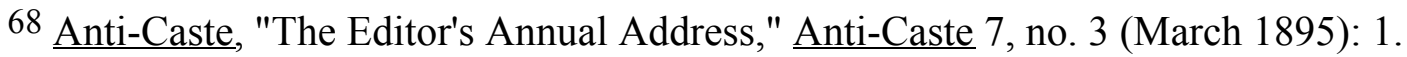


Know." Therefore, she made consistent appeals to Americans to live up to their Constitutional ideals. ${ }^{69}$

Impey saw amending the American Constitution to "enforce its own declared first principles, and protect the lives and liberties of those who live under it" as a possible step toward abolishing lynchings. She also believed that the intervention of white women in the cause would have a beneficial effect. "What strikes me as a serious lack in the defense of the negro in America," she said, is that:

Among the whites no woman as yet appears. Until some brave women take up again the cause of liberty and humanity, like the heroic band who were the strength of the anti-slavery movement, we shall not be able to feel that the cause has yet entered the hearts and homes of the people. ${ }^{70}$

The involvement of white women in the American aspect of the antilynching movement was not a component of the nineteenth century phase of the movement. Their presence would become more of a factor during the twentieth century as the NAACP, the Association of Southern Women For the Prevention of Lynching, and other white women's groups began to actively promote anti-lynching legislation. ${ }^{71}$

${ }^{69}$ Catherine Impey, Untited article, Anti-Caste, 2, no. 3 (March 1889): 2.

70 Catherine Impey, "The Editor's Annual Address," Anti-Caste, 3, no. 1 (January 1890): 6. 
Impey's most intense period of focus on African American problems was from the late 1870 s to the mid 1890 s -- approximately eighteen years. It was just after Ida B. Wells' lecture tours in the United Kingdom that Impey's anti-racist activities appear to have slowed down. What initiated her withdrawal from the cause was an incident which led to the destruction of Impey's relationship with another key figure in the movement, Isabella Fyvie Mayo.

Impey and Mayo had worked together in bringing Wells to the United Kingdom and in founding the SRUBM. Established in 1893 when Wells arrived in the region, the SRUBM served as a promotional vehicle for her lectures and for the espousal of universal brotherhood. Impey worked as a representative of the SRUBM when promoting Wells' speaking engagements, but she had divorced herself from the organization by the time of its greatest involvement in the anti-lynching campaign (1894-1897). ${ }^{72}$

As a philanthropist and friend of Indians in Scotland, Mayo had enlisted

\footnotetext{
71 Mary Jane Brown, Eradicating This Evil: Women in the American Anti-Lynching Movement, 1892-1940 (New York: Garland Publishing, Inc., 2000), 174.

72 For the establishment of the SRUBM see Duster, Crusade For Justice, 87. Also Ware, Beyond the Pale, 175. For more detailed information on the SRUBM see most issues of its organ, Fraternity, edited by Celestine Edwards.
} 
the help of Indian students residing in her home in the creation and distribution of flyers announcing Wells' speaking engagements. Impey had become romantically attracted to George Ferdinands, a dental student from Ceylon, and with the intention of initiating an open relationship with him, she wrote him a letter revealing her attraction. Ferdinands, not sharing Impey's affections, showed the letter to Mayo, who became outraged over Impey's impropriety and proceeded to dismantle their relationship by severing all ties to Impey. ${ }^{73}$

Although Impey's willingness to go "beyond the pale" and act on romantic inclinations exemplified her commitment to an anti-caste philosophy, the stress of the situation led her to cease publication of AntiCaste for one year in 1894. Publication was resumed briefly in March of 1895, at which time it was distributed free of charge. That, however, was the final issue, although the editor had indicated an intention to permanently resume publication of the journal:

Dear Friends, - You will see by the enclosed letter to the Secretary of the SRBM [the name had been shortened by this time], that I and a number of our Anti-Caste colleagues

73 For details related to this incident, see Duster, Crusade For Justice: The Autobiography of Ida B. Wells. Also, Ware, Beyond the Pale: White Women, Racism and History. 
have withdrawn from that Society. It was found with regret that there existed among the members of our Committee so fundamental a difference of view as to the lines of personal conduct required of us, in view of the great evil of the caste system (as between white and dark races), that united working was seen to be impracticable. Although the originators of the movement, we therefore withdrew, leaving with others the bond of brotherhood which we had just so hopefully started together. It is with much sorrow and a deep sense of personal unfitness for so arduous a task that I have resolved to resume the publication of Anti-Caste, for a time suspended in hope that the needs of the case might be met by other publications. I feel, however, that its voice is again needed. ${ }^{74}$

Occurring simultaneously with the above mentioned activities which led to the decline of Anti-Caste was the failing health and eventual death of Impey's mother, who had become ill in 1895 and died just months later. Hannah Impey had been a great source of inspiration to Catherine in her reform work and the publication of Anti-Caste. Her sudden absence, along with the poor health of her sister, Nellie, likely created a significant change in Impey's life. ${ }^{75}$

The involvement in the anti-lynching campaign and the editorship of Anti-Caste represent the most documented phase of Impey's life. Unfortunately, her diaries have been lost, and little is known of her activities

\footnotetext{
${ }^{74}$ Catherine Impey, "The Editor's Annual Address," Anti-Caste, V11 (March 1895): 1.

75 Ware, Beyond the Pale, 190.
} 
after the cessation of the English anti-lynching campaign. Certain writings show that she championed women's causes and supported the Women's Suffrage movement, and considering her commitment, it is very probable that she remained a force in the struggle for human equality.

Catherine Impey fulfilled her goal of assisting African Americans in their struggle against oppression. A philanthropist to the cause, she followed through on her convictions and extended herself monetarily, but primarily through service. By providing a forum for the African American dilemma, sentiment was generated which impacted favorably on the anti-lynching movement. Impey was the reason that there was a reaction to lynchings in the United Kingdom. Moreover, her efforts were greatly assisted by the circle of American journalists, editors, and supporters, who first spoke out against lynchings in the early 1880 s and who stated and reiterated the American condition throughout the publication of Impey's journal Anti-Caste. 


\section{CHAPTER TWO}

\section{T. Thomas Fortune and the Afro-American League}

T. Thomas Fortune exemplified the type of support that Catherine Impey needed and utilized in her attempt to expose lynchings in America to the global community. Fortune's editorship of three African American newspapers in the late nineteenth century showcased his political and philosophical views on lynching and other aspects of discrimination in America from the early 1880s. Journalism was the vehicle through which Fortune obtained support for the establishment of an anti-discrimination organization. It was also the means by which he became a major participant in the trans-Atlantic connection of the anti-lynching movement.

African American journalism began to proliferate after the abolition of slavery, primarily as an instrument of influence during changing conditions and as a source of information for newly established African American communities. The first black newspapers were northern enterprises which were established during the antebellum era as early as 1827 , that region of the country being the location of a significant number of free blacks who had acquired some education and who were concerned about the extension of 
rights for free blacks as well as freeing those still in bondage. It was not until slavery ended that blacks in the South had the liberty to pursue journalism and a literate community anxious to read their editorial and news items. $^{1}$

Black newspapers were established in response to racism and as a means of racial uplift. "Race was their raison d'etre. They were published by black men for black readers." 2 The first African American newspaper, Freedom's Journal, published in New York in 1827 by editors Samuel Cornish and John B. Russwurm, attempted to furnish its readers with national and international current events, as well as editorials related to slavery, lynching, and other injustices. ${ }^{3}$

There were varying degrees of radicalism among black newspaper editors, but typically, all protested racial injustice and reported on individual, organizational, and community achievements in their papers.

There were boundaries however, to what editors could write without

${ }^{1}$ I. Garland Penn, The Afro-American Press (New York: Arno Press, 1969), 25. Also see Penelope Bullock The Afro-American Periodical Press, 1838-1909 (Baton Rouge: Louisianna State Press, 1981).

${ }^{2}$ Emma Lou Thornbrough, T. Thomas Fortune: Militant Journalist (Chicago: University of Chicago Press, 1972), 38.

3 All 103 issues of Freedom's Journal have been placed in digitized form. See: http://www.shsw.wisc.edu/library/aanp/freedom/ 
risking the wrath of the white press, the white community, and conservative, mainstream blacks. A few editors crossed those boundaries, their outspokeness placing them in the category of what Henry W. Grady of the Atlanta Constitution coined the "Afro-American agitator."4 This confrontational approach of blacks who advocated equal political, educational, and social rights for African Americans was in sharp contrast to the accommodationist stance of Booker T. Washington and the more conservative element of the black community who tended to follow his philosophy. ${ }^{5}$

Ida B. Wells of the Memphis Freespeech and William Monroe Trotter of the Boston Guardian are examples of aggressive atypical journalists of the late $1800 \mathrm{~s}$. However, as the tide of racial violence and discrimination rapidly increased, it was T. Thomas Fortune, editor of the New York Age, whose journalistic approach distinguished him as the most militant African American newspaper editor of that era. Having first edited the New York

\footnotetext{
${ }^{4}$ Henry W. Grady, "Afro-American Agitator," Atlanta Constitution 12 December 1895: 12.

${ }^{5}$ Several sources examine the life and philosophy of Booker T. Washington. Two prime examples are: Louis Harlan, Booker T. Washington: The Making of a Black Leader. (Oxford: Oxford University Press, 1972), and August Meier, Negro Thought in America, 1880-1915: Racial Ideologies in the Age of Booker T. Washington. (Ann Arbor: University of Michigan Press, 1963).
} 
Globe in 1883, which evolved to the New York Freeman in 1884, and then the New York Age in late 1880s, the paper served as a vehicle for promoting Fortune's political views and meeting the needs of the newly developing black population of New York. ${ }^{6}$

Although the great migration of southern blacks into New York City had not yet begun, the "bustling metropolis" was already home to a significant number of African Americans. When Fortune arrived in 1881, the total population of $1,700,000$ consisted of 28,815 blacks in New York City, with 13,093 in Manhattan and 9,153 in Brooklyn. Most of them were descended from enslaved Africans or free blacks who had been in the North before the American Revolution. ${ }^{7}$

Fortune's background was an exception to that of the typical African American resident of New York. Having emigrated from Florida, his radicalism had its roots in his southern American experience. He was born Timothy Thomas Fortune in Marrianna, Florida, on October 3, 1856, and was the first son of Emanuel and Sarah Jane, who were slaves of Eli P. Moore. During enslavement, Fortune's father had the rare opportunity of

\footnotetext{
${ }^{6}$ Thornbrough, T. Thomas Fortune, 35.

${ }^{7}$ Ibid.
} 
learning to read and of gaining skills in shoemaking and tanning. ${ }^{8}$

After emancipation and during the Reconstruction era, T. Thomas

Fortune attended school taught by Union soldiers and organized by the Freedmen's Bureau. He also had his initial exposure to journalism in the office of the Marrianna Courier, the county's weekly newspaper. He was so fascinated by what went on there that "he became a fixture and soon learned to stick type."9

Emanuel Fortune took an active political and leadership role in Marrianna during the brief period of Reconstruction. He was one of two black delegates chosen from the area to serve at the state constitutional convention in 1868. In the selection of the first legislature following the adoption of the new constitution, Emanuel Fortune was elected to the state House of Representatives. In that capacity, his performance was typically moderate, but he was known to be immovable on issues about which he felt strongly.

In 1869, young Timothy was given the opportunity of serving

\footnotetext{
8 Cyrus Field Adams, "Timothy Thomas Fortune: Journalist, Author, Lecturer, Agitator," The Colored American Magazine, January-February 1902: 225.

9 Thornbrough, T. Thomas Fortune, 9.
} 
as a page in the State Senate. It was that early, close-up experience that opened his eyes to a disparity between the promises and actualities of the white Republican politicians with which blacks were so closely associated. He became suspicious and distrustful of politicians and the agendas of political parties in general, and therefore remained primarily nonpartisan throughout most of his life, later stating that he had:

served the Republican Party, the Prohibition Party, the Democratic Party, ... a and I speak with the wisdom of experience when I declare that none of them cares a fig for the Afro-American further than it can use him. ${ }^{10}$

Emanuel Fortune's involvement in politics made him a target for the $\mathrm{Ku}$ Klux Klan, which became part of a very definite move to restore Democratic control in Marrianna, Florida. The reacton of whites to domination by a Radical Republican government supported by black votes resulted in several violent retaliations. To protect himself, Emanuel Fortune was forced to leave his home for several months. Although the family was later reunited in Jacksonville, Florida, the fear and hardship of the situation left an indelible impression on T. Thomas. ${ }^{11}$

The move from Marrianna exposed T. Thomas to greater educational and
${ }^{10}$ Ibid., 114.
${ }^{11}$ Ibid., 10. 
employment opportunities. After spending his adolescence in Jacksonville and Tallahassee, where school sessions were longer than they had been in Marrianna and also where he had job experiences which expanded his knowledge of newspaper printing and politics, he left Florida in 1874 to attend Howard University in Washington D. C. ${ }^{12}$

Fortune's course emphasis at Howard revolved around his interest in history and politics, but his goal was to complete law school. Living in Washington and attending Howard expanded his social and intellectual experiences. He also became acquainted with political figures such as Frederick Douglass, who was then marshal of the District of Columbia. However, Fortune's educational plans were interrupted after just one year at Howard because of the failure of the Germania Bank, where he had deposited his savings. As a result, he was forced to drop out of school and seek employment. He found a job at a local newspaper and married his high school sweetheart. Eventually, financial hardship in Washington led them to return to Florida where Fortune worked briefly as a school teacher under conditions which he found to be "insufferable." Therefore, determined to create a better existence, the couple left Florida in 1881 and

12 Ibid., 24. 
moved permanently to New York. ${ }^{13}$

For fear of reprisals, many African American journalists were uncomfortable speaking out against crimes directed at their race. This was particularly a much riskier position for southern journalists to place themselves in than it was for those in the North, even though racial violence was not totally limited to the southern states. There were threats and incidences of attacks on those who did speak out, and oftentimes the black editor was probably only a few hours ahead of a lynch mob. Ida B. Wells provided a good example of that when she took the white press of Memphis to task for indescriminate lynchings. As a result, her editorial partner was run out of town, the Freespeech office was trashed, and Wells was forced into exile. ${ }^{14}$

T. Thomas Fortune openly and ardently reported on and denounced lynchings early in his jounalistic career. For example, an article appeared in the Freeman in December of 1887, describing the lynching of John Bigus in Frederick City, Maryland, which was reported to be "the most appalling

13 Ibid., 32.

14 Alfreda M. Duster, ed., Crusade For Justice: The Autobiography of Ida B. Wells (Chicago: University of Chicago Press, 1970), 65. 
murder that has ever taken place in this community." Bigus had been accused of sexually assaulting a white woman, and after being arrested, he was taken out of jail by "a mob of one hundred men [who] surrounded the door and took him a short distance from the jail, riddled him with bullets and hung him."15

Fortune at this time was very adamant about making a statement against injustice. For example, in responding to a letter that Catherine Impey had written him regarding the attempt to segregate the various chapters of the Order of Good Templars, a temperance organization, he stated that he had once been a member of the organization but had resigned after discovering hypocrisy and discrimination. "Such moral movements like that of temperance" he said, "should not be shaken by compromise." He further proclaimed that "what is right is right and it is better to be a minority of one for right than a majority of a million for injustice."16

Discouraged by the inability of individuals to effect change in the status and treatment of African Americans, Fortune began to conceive the idea of a national organization that would utilize written and verbal agitation, the

\footnotetext{
15 T. Thomas Fortune, "Lynching in Maryland," The New York Age, 31 December 1887.

16 T. Thomas Fortune to Catherine Impey, 20 April 1887, reprinted in The New York Freeman, 20 May 1887.
} 
ballot, and the courts to combat violence and discrimination toward blacks. Although his experience with political parties had left him disillusioned in terms of their relationship with blacks, he recognized the power of the ballot and continued to seek a viable avenue from which African Americans could approach the political arena.

Fortune was encouraged by publicity related to the Irish protests of British misgovernment and the denunciation of that misgovernment in American newspapers. Although a study of American history during that era reveals a strong prejudice toward African Americans by many Irish Americans, Fortune was convinced that it was because the Irish had a political voice in America that the press elicited such a response. He reasoned that the demands of a politically active force of blacks would be taken seriously as well. Therefore, the Irish National League became a paradigm for the establishment of The Afro-American League, an organization that would incorporate local and state chapters from all areas of the country. ${ }^{17}$

Fortune began an article related to lynching and the Irish question

17 T. Thomas Fortune, "A Proposed Afro-American National League," The New York Freeman, 28 May 1887. 
by stating:

There should be some way to suppress mob law in the South. Not a day passes that the papers do not record some hideous outrage of this kind ... There can be no possible excuse for this constant murder of colored men by irresponsible citizens ... The papers of this country are loaded down with denunciations of British misgovernment of Ireland (and we agree with the denunciations), and the woeful conditions of the Irish poor is made the subject of monster meetings, where oratory intended to capture or conciliate Irish voters runs like wild fire in every direction. ${ }^{18}$

The first mention of establishing an organization such as the AfroAmerican League, came at an integrated dinner gathering of the Charles Sumner Union League in Hartford, Connecticut, in January 1884. As part of a speech delivered during the event, Fortune emphasized the necessity of addressing evolving segregated conditions and stated that it was only in "Connecticut and Massachusetts that such a meeting could occur." $19 \mathrm{He}$ concluded by suggesting that the Sumner Union League make itself a central organization from which would radiate kindred organizations. There was some promotion of the organization in the Freeman from time to time, but it was not until 1887 that Fortune's formulated vision of the organization appeared in the newspaper. ${ }^{20}$

18 Ibid.

${ }^{19}$ Thornbrough, T. Thomas Fortune, excerpted from an article originally appearing in the Hartford Telegraph and reprinted in The New York Globe, 1 January 1884: 106. 
Advocating peaceful coexistence between blacks and whites in America naturally included addressing many areas of injustice. In most cases, those who campaigned for the restoration of political rights were usually opposed to segregation and mob violence as well. It would be inconsistent and difficult to oppose racial violence without denouncing other forms of discrimination and also promoting possible solutions to violence such as political freedom. The mission of the Afro-American League was to become an instrument of empowerment for the African American community by confronting all areas of obvious and serious oppression which included :

The almost universal suppression of the ballot ... The universal and lamentable reign of lynch and mob law ... The unequal distribution of school funds ... The odious and demoralizing penetentiary system of the south . . . chain gangs, convict leases, and indiscriminate mixing of males and females. The almost universal tyranny of common carrier corporations in the South -- railroad, steamboat, and other . . . The general policy of those who conduct places of public accommodation ... ${ }^{21}$

Fortune envisioned the League as being concentrated in the southern

${ }^{20}$ Fortune, "A Proposed Afro-American National League," New York Age, 28 May 1887.

21 T. Thomas Fortune, "The Proposed Afro-American League," New York Freeman, 4 June 1887. 
states because the majority of blacks resided there, and it was they who were experiencing the greatest amount of oppression. He viewed the chapters of the league in the North and West as serving to "coerce politicians into taking a broader view of ... grievances and to compel them to pay more respect to representations and requests." 22 Fortune evidently expected the League to follow his example of agitation to bring about change. Although noting that blacks in the North were not "restrained in the free exercise of the ballot," as southern blacks were, he acknowledged that northern blacks had little influence, and believed that it was only by organizing and protesting as a group that an advantage might be gained. ${ }^{23}$

That the creation of an Afro-American League was percieved of as an instrument of political power intended to bring a change in the prevalence of lynch law was evident from the initial response of some black leaders and corresponding newspaper editors. A correspondence from a Baltimore newspaper appearing in the New York Freeman reflected the sentiment that their citizens had "favorably commented" on the organization and viewed it as "a harbinger of a better state of affairs on account of the lynching mania

\section{Ibid. \\ ${ }^{23}$ Ibid.}


that has taken hold of the whites."24 The Rev. B. M. Taylor of the Methodist

Episcopal Church of Salina, Kansas, wrote an editorial describing the inhumane treatment of blacks in Texas on several levels, and encouraged blacks to:

take hold of the Afro-American League as proposed by Mr. Fortune. This movement, if carried out according to ... plans will help the entire race and will rob neither man, woman, nor child, but will give ample protection to the entire race. ${ }^{25}$

The article concluded with an appeal for African American political unity and a "need to know how to vote for a policy to do away with lynch-law."26 Fortune himself focused on lynchings in an initial article promoting the creation of the League in which he stated:

There should be some way to suppress mob law in the South. Not a day passes that the papers do not record some hideous outrage of this kind "by our best people,"and the victim is invariably some one or more colored men who are suspected of some sort of crime, but who are entitled to a fair and impartial trial by jury of their peers, and who are in the sight of the law presumed to be innocent until proven to be guilty . . ${ }^{27}$

24 Baltimore Correspondent, "Lynching in Maryland," New York Freeman, 13 July 1887.

25 B. M. Taylor, "Samples of Southern Outrages," Anti-Caste, 1, no.3 (May 1888): 2.

26 Ibid., 4.

27 T. Thomas Fortune, "The Proposed Afro-American League," The New York Age, 28 May 1887. 
Although political assertiveness was not usually associated with the design for progress professed by Booker T. Washington, he did nevertheless endorse the establishment of an Afro-American League. "Push the battle to the gate [ and] let there be no hold-up until a League shall be found in every village. God bless you. God bless the proposed League."28

Opposition to the organization inevitably appeared in the white press, but editorials written by blacks who feared reprisals from the white community also appeared in African American newspapers. Even the Southern Leader in Jacksonville, Florida, Fortune's hometown, stated that "the League would intensify rather than alleviate race troubles."29

In addition, certain African American leaders such as Frederick Douglass, P. B. S. Pinchback, and Blanche K. Bruce never became associated with the Afro-American League. Certainly the principles for which it stood were supported by such leaders of the race. For various reasons, however, they addressed the issues through other avenues. In the 1880s, the term "AfroAmerican" was a radical departure from "Negro" or "Colored" in categorizing African Americans. That Fortune intended the League to be a

\footnotetext{
28 Thornbrough, T. Thomas Fortune, 108.

${ }^{29}$ Ibid.
} 
"militant force" was clearly evident by the use of the term "Afro-American" and by the encouragement to "agitate, agitate, agitate, until the protest shall awake the nation from its indifference." 30 Some African American leaders may have been reluctant to risk being labeled a radical, militant, or Afro-American agitator, particularly if they were involved in politics or had political aspirations, as did Douglass, Bruce, and Pinchback. ${ }^{31}$

An event at the World's Columbian Exposition in Chicago in 1893 might provide an example of the response of moderate and radical race leaders to certain issues. In protest of the exclusion of African American contributions to the advancement of the free world, Ida B. Wells, attorney Ferdinand L. Barnett, I. Garland Penn, and Frederick Douglass collaborated on a booklet titled The Reason Why the Colored American is Not Included in the World's Columbian Exposition. To appease the protestors and in response to interest in African American contributions generated by the protestors, officials of the fair agreed to allow a one day program honoring African Americans. Ida B. Wells, the pinnacle of radicalism considered this a slap in the face and

30 Thornbrough, T. Thomas Fortune, 106. Excerpted from article carried in New York Globe, 19 January 1884.

31 August Meier, Negro Thought In America, 1880-1915: Racial Ideologies in the Age of Booker T. Washington (Ann Arbor: University of Michigan, 1966), 78. 
refused to participate, whereas the diplomatic Frederick Douglass perceived the compromise in a different light and planned a grand program.

Afterwards, Wells acknowledged that Douglass had taken the wiser course and stated that he had produced a successful program "without any aid from us hotheads." 32

In general, the proposed Afro-American League received a favorable response from most of the black press, particularly in the North, and it was endorsed by a number of prominent African Americans and African American organizations. ${ }^{33}$

In November of 1889 , Fortune attempted to create a strong national organization by unifying existing local chapters of the Afro-American League. To that end, he issued a call for delegates to convene in Nashville, Tennessee. Considering, however, the difficulty of obtaining public lodging for attendants and the inherent danger of meeting in a southern city, the location was changed to Chicago. To stimulate interest in the convention, Fortune wrote the following letter and published it as an appeal in his newspaper:

32 Duster, Crusade For Justice, 118.

33 Thornbrough, T. Thomas Fortune, 107. 
To the colored Citizens of the Republic: Being convinced that the time is ripe for the organization of the National AfroAmerican League, proposed by me two years ago, to successfully combat the denial of our Constitutional and inherent rights, so generally denied or abridged throughout the Republic, and being urged to do so by members of branch leagues all over the country, I, by these presents, issue a call to all the branches of the Afro-American League, and invite all clubs and societies organized to secure the rights of the race, to meet by representatives in National Convention at Chicago, Ill.,Wednesday, January 15, 1890, for the purpose of organizing a National Afro-American League; the basis of Representation to be four delegates for every one hundred members, or one delegate for every twenty-five members, constituting the branch league, club or society, desiring to cooperate in the movement for National organization.

Correspondence from all organizations desiring to join in this movement is requested. ${ }^{34}$

The appeal was answered by leading African Americans such as:

Alexander Walters, New York

J. Gordon Street, Massachusetts

W. A. Pledger, Georgia

Robert Pelham, Jr., Michigan

Edward E. Cooper, Indiana

H. C. Smith, Ohio

John Mitchell, Jr., Virginia

Magnus L. Robinson, Virginia

J. C. Price, North Carolina

Thomas T. Symmons, District of Columbia

F. L. Barnett, Illinois

Z. T. Cline, New Jersey

Van N. Williams, Alabama

B. Prillerman, West Virginia

Wm. H. Heard, Pennsylvania

${ }^{34}$ T. Thomas Fortune, "To the Colored Citizens of the Republic," New York Age, 4 November 1889. 
R. K. Sampson, Tennessee

H. M. Morris, South Carolina

James G. McPherson, Mississippi

When the convention was held, on January 15, 1890, a total of 140

delegates came from twenty-one states. A national league was established with the Rev. J. C. Price of Livingstone College elected as president, T. Thomas Fortune, as secretary, and George Jackson, as treasurer. The following year, 1891, Price was succeeded by Fortune as president. ${ }^{35}$

The establishment of the Afro-American League caught the eye of Catherine Impey, the concerned, pro-active English editor of Anti-Caste, who provided a vehicle for extending Fortune's editorial voice beyond the shores of America. When Impey began to edit the journal in 1888, Fortune's editorials in the Age and his previous correspondence with Impey served as readily available material to be utilized in the new publication. Introduced as a friend of the journal and a "leading Coloured American," the first of Fortune's articles to appear in Anti-Caste was a reprint of the entire manifesto for the proposed Afro-American League. The manifesto had previously appeared in the June 1887 issue of the New York

Freeman. ${ }^{36}$ What that did for the readership of the journal was provide a

35 Alexander Walters, My Life and Work (New York: Fleming H. Revell Company, 1917), 97. 
clear picture of the issues around which African American inequality revolved.

Fortune's article, "The Negro and American Politics," written especially for the December 1888 issue of Anti-Caste, was a plug for the political involvement of blacks as a necessary component of liberation and a comparison between the political ambitions and involvements of blacks, whites, southerners, and northerners. For aspiring whites, he said, "partisanship always runs tide high, violence seldom follows, except in the southern states where the bulk of the coloured voters reside." Stating that in the North and West, political concerns included "tariff revisions and surplus reduction, the reform of civil service, prohibition of the rum traffic, and cognate questions of administration" he noted that "the one question in the South to which all others are remorsely subordinate is: How shall we keep the Negro in his place? . . the only answer yet found is the barbarous one: The shot gun." 37

Fortune also made an issue in the article of the fact that whites were

36 T. Thomas Fortune, "The Proposed Afro-American League," Anti-Caste 1, no. 1 (March 1888): 2-3.

37 T. Thomas Fortune, "The Negro and American Politics," Anti-Caste 1, no. 10 (December 1888): 1. 
politically dominant in areas where blacks represented an overwhelming majority of the population. Acknowledging that every one of the southern states was dominated by whites although many states had a considerable African American majority, he relegated the situation to a problem of race domination rather than to that of a particular party. This was highlighted by Catherine Impey's inclusion of specific information from American newspapers. For example, to further make that point, she emphasized quotes such as "the election at Jackson, Mississippi is passing quietly. There will be no trouble unless the negroes attempt to vote." 38

Most of Fortune's editorial contributions to Anti-Caste related to the Afro-American League as the solution to addressing the problem of lynching and other forms of racial discrimination. The formation of the League generated a great deal of interest and effort in the late 1880s and early 1890s. Although it was intended to be a powerful national organization, it had greater sucess on the local level. Fraught with financial limitations, members of local chapters found it difficult to attend national meetings, and the lack of certain prominent figures as members is also considered to have affected the cohesiveness of the organization. There were a couple of

38 T. Thomas Fortune, "Afro American League: Important Speech," Anti-Caste, 3, no.2 (February 1890): $1 \& 3$. 
personal victories in which Fortune instigated litigation against a hotel and a theatre for discrimination, but even though he won the suits and was awarded financial compensation, the actions did not have the effect of strengthening the League. ${ }^{39}$

As a result of these factors and because there failed to be a national convention in 1892, the League was temporarily disbanded. In August 1893, Fortune announced its demise by stating that "it was defunct because of lack of funds, lack of mass support, and indifference of race leaders." 40 The continued need to address all of the original grievances of the AfroAmerican League led to the reformation of the organization under the name Afro-American Council in the late 1890s. Fortune's call to reassemble the group attracted newcomers such as Ida B. Wells-Barnett, who by then had established herself as a committed crusader against lynchings. This had the effect of briefly stabilizing the organization. The re-establishment of the League came at a time when Wells-Barnett had become discouraged by a lack of support for her individual anti-lynching efforts in America, and she "welcomed the opportunity of helping to unite the race in the arduous work

${ }^{39}$ Thornbrough, T. Thomas Fortune, 120.

${ }^{40}$ Ibid.,122. 
necessary." 41

The policy of the newly formed Afro-American Council was to denounce wrongs and injustices directed at African Americans -- a policy that had already been established by the Afro-American League. As Fortune had intended initially, the organization was determined to use its influence to bring about changes. "Especially strong," according to Wells-Barnett, "was condemnation of lynch-law and those who protected it." Because of her outstanding work in the area she was elected chairman of the Council's antilynching committee during the organization's first annual meeting in $1899 .{ }^{42}$

The revival of the League as the Afro-American Council brought some successes and greater unity to the organization in its initial years, but its progress was later stifled by "internal dissension and ... inadequate financial support." Although Fortune's influence and particpation diminished in later years, it was his initial work with the League that formed the foundation upon which the Council stood. ${ }^{43}$ The inclusion of Fortune's

${ }^{41}$ Duster, Crusade For Justice, 255.

42 Ibid., 265.

${ }^{43}$ For insight on the Afro-American League and Afro-American Council, see Emma Lou Thornbrough, "The National Afro-American League, 1887-1908," The Journal of Southern History 27, no.4 (November 1961): 494-512. 
editorials in Catherine Impey's English journal Anti-Caste and its successor Fraternity, played a primary role in awakening English sentiment to evolving terrorist actions against African Americans from the late 1880s, at least five years before Wells-Barnett began to actively campaign against lynchings. 


\section{CHAPTER THREE}

\section{Albion Winegar Tourgee: Radical Republican and Civil Rights Advocate}

The position on lynching taken by African American journalists and orators in the initial phase of anti-lynching agitation was joined by the voice of Albion Tourgee. As a lawyer and judge, Tourgee used a variety of expressions to advocate for justice and equality of African Americans. He became entrenched in the southern American political arena during the Reconstruction period and was compelled to seize opportunities to advance the cause of blacks. As a writer, his novels largely captured the repressive, degenerate character of southern American racism and articulated the African American condition which functioned as a recipient of racist behavior. A white American and friend of the African American community, Tourgee was among the first to bring attention to the incivility of lynchings.

Catherine Impey was magnetically drawn to Tourgee via the position that he took on lynchings and discrimination in general and cast him in the same light as other neo-abolitionists in America. She perceived them to be leaders destined to make a difference in the lives of African Americans and 
conveyed that image of them to the readers of Anti-Caste:

Our crowning desire in crossing the Atlantic this time had been to meet with some of the leaders of the new movement, for to us it seems the most momentous step that has been taken in America in the cause of liberty since the organization of the old Anti-Slavery Society. 1

Having just returned to London from a trip to America in October of 1892, Impey made a full report of her observations to the readers of Anti-Caste. She had first gone to Canada to attend to family business but stopped in America afterwards and "allowed herself the priviledge of a few weeks visit among friends of the Negro cause." 2 After pointing out that: the trip included visits of several days to a week at the homes of Albion W. Tourgee on the picturesque shores of Lake Chatauqua in the state of New York; Mr. and Mrs Frederick Douglass at beautiful Cedar Hill, near Washington; of Mrs. F. J. Coppin, Principal of the 'Institute of Coloured Youth,' at Philadelphia; and of Bishop and Mrs. Tanner and their family on the borders of the same city. ${ }^{3}$

The editorial was punctuated by bits of information about the condition and status of blacks in America evidently gleened from her conversations and observations abroad. In lamenting the "horrors of Negro life in the South, the outrages to which these men and women are subjected, the shootings, the

\footnotetext{
${ }^{1}$ Catherine Impey, "America Re-Visited," Anti-Caste5, no.9 (October, 1892): 2.

2 Ibid.

${ }^{3}$ Ibid.
} 
burnings, the almost daily murders, -- euphemistically called lynchings," 4 she referred her readership to the efforts of Albion Tourgee as someone working to alleviate the problems. ${ }^{5}$

Impey was herself very much aware of Tourgee's efforts and background, having read his books A Fool's Errand and Bricks Without Straw, both of which revealed Tourgee's equalitarian philosophical leanings. Impey reminded her reader's of Tourgee's reputation as a writer and noted that he was "not yet so widely known as the author and chief director of the new Anti-Slavery Society, to which [she had] called attention in former numbers of Anti-Caste." 6

Albion Tourgee's prominence sprang from and is directly related to the Reconstruction era and the socio-political, as well as economic, problems of newly emancipated African Americans. Those were the conditions which thrust him into the arena of civil rights for which he advocated and agitated throughout the Reconstruction/Gilded Age eras. His sensitivity to dramatic issues such as lynchings, segregation, and disfranchisement placed him in high esteem among African Americans and other libertarians. It is what inspired the members of the "Ida B. Wells Club" to refer to themselves initially as the "Tourgee Club," and his modern

\footnotetext{
${ }^{4}$ Ibid.

5 Ibid.

${ }^{6}$ Ibid.
} 
editor and biographer, Otto $\mathrm{H}$. Olsen to say that Tourgee, during the late 1800s may have been "the most militant, vocal, persistent, and widely heard advocate -- black or white -- of racial equality in the United States."7 Ida B. Wells-Barnett considered him to be "an earnest, faithful advocate and representative" of African Americans. ${ }^{8}$

Born in Ashtabula, Ohio, on May 2, 1838, Tourgee may have been destined to the path that he followed. His paternal ancestors had become exiles when it became unsafe for Hugenots to remain in France. They made their way across the Atlantic, going successively to Rhode Island, Massachusetts, and Ohio. Some of his maternal forebearers were from the German Palatinate; others came from England on the Mayflower and finally made their way to Ohio's Western Reserve region where Tourgee's mother Louisa Winegar and his father Valentine Tourgee met and were married. Of the three children that the Tougee's had, Albion was the only one to survive infancy. ${ }^{9}$

Tourgee developed a love for books at an early age and had begun to write in his teens while attending the Kingsfield Academy in Ohio. His

\footnotetext{
${ }^{7}$ Albion Tourgee, Bricks Without Straw, Otto H. Olsen, ed. (Baton Rouge: Louisiana State Press, 1969), xix.

${ }^{8}$ Ida B. Wells to Albion Tourgee, letter printed in The Conservator 15 May 1897, The Ida B. Wells Papers, Special Collections, Reggenstein Library, University of Chicago.

${ }^{9}$ Albion W. Tourgee, A Fool's Errand, John Hope Franklin, ed., (Cambridge: Harvard University Press, 1961), viii.
} 
poems and essays were compiled in a collection entitled "Sense and Nonsense" in 1857. Course work began at Rochester University in 1859, and although he had only attended two years when the Civil War broke out, he was awarded his Bachelor of Arts degree as was customary with students who became enlistees. ${ }^{10}$

Soon after entering the war effort on the side of the Union, Tourgee suffered a spinal injury in the Battle of Bull Run and was discharged as a result. While recuperating, he spent a period of time lecturing and recruiting civilians to the military. In 1862, although still recovering, he reentered the army as a lieutenant with Company $\mathrm{G}$ of the 105th Ohio Volunteers, during which time he was put under military arrest for refusing to surrender a black man who had saved his company. ${ }^{11}$ Several months later he was again injured and briefly hospitalized. His capture and imprisonment by the Confederates, who eventually exchanged him in 1863 , concluded his military career. ${ }^{12}$

By the time the war ended, Tourgee had acquired a law degree and a wife, and had decided to leave Ohio and take up residence in Greensboro, North Carolina. This action put him in the category of being labeled a

10 Roy F. Dibble, Albion W. Tourgee (Port Washington: Kennikat Press, Inc., 1921, revised, 1968), 16-21.

11 Tourgee "Letter to the editor," The Chautauquan, Vol. 2 (November, 1881): 93.

12 Thomas Carey, "Albion Winegar Tourgee: Altruist or Cynic," (Ph.D diss., St. John's University, 1950), 3. 
"carpetbagger," those persons described by unfriendly early historians as "northern men who came South after the War between the States, in hope of obtaining place and profit out of the wreckage of the defeated Confederacy."13 The term "carpetbagger" refers to the carpet-bag, "the rude hand baggage of the era, in which these political adventurers were supposed to have brought their belongings." 14 Though not considered to have been a typical carpetbagger because of his sincerity in uniting the region and helping the freedmen, Tourgee "moved to Greensboro in a typically American search for comfort and economic opportunity," and did not anticipate the political role that he would eventually play. ${ }^{15}$

Immediately upon his arrival in the South he became part of the Radical Reconstruction effort. Like many Radical Republicans, Tourgee considered himself to be on "an errand of enlightenment." He intended to help establish racial equality in the "poor, misguided, and mismanaged South, to loose southerners from the sloth of ignorance and Prejudice."16 In August 1866, he attended a Republican Party meeting and came out strongly for black suffrage which he again advocated at the Philadelphia Convention

13 William A. Devin, "Footprints of a Carpetbagger," The Torch, 17 (April 1944): 16. 14 Ibid.

15 Tourgee, Bricks Without Straw, viii.

16 Theodore L. Gross, Albion W. Tourgee (New York: Twayne Publishers, Inc., 1963), 21. 
of Southern Loyalists a month later. ${ }^{17}$ Tourgee supported political involvement for blacks, but he did not believe in blanket enfranchisement without certain qualifications such as education. To that end, he ardently promoted equal educational opportunites for African Americans, believing that education would enable them to make sound political choices. In 1867, Tourgee organized the Union League which encouraged political participation among blacks, and he started a newspaper, The Union Register. ${ }^{18}$

Against the protestations of some of the state's government officials, such as Gov. Jonathan Worth, Albion Tourgee was elected judge of North Carolina's Superior Court, Seventh Judicial District, in 1868. Although he sought to reform the South in ways that southern whites objected to, his constituents evidently believed in his ability to administer judicial affairs competently. Tourgee elaborated upon his convictions in his acceptance speech for the nomination:

In accepting the nomination I speak as a Republican. . . For this party therefore I am ready and willing at all times and in all places to labor. . I It has been said that a judge should not be a partizan [sic] in so far as the performance of judicial duties. I cannot accede to the proposition that it is the duty of a judge to so far forget his citizenship, and all the grand interests and duties which cluster around and adorn

\footnotetext{
${ }^{17}$ Carey, "Albion Wingar Tourgee," 9.

18 Tourgee, Fool's Errand, xii.
} 
the relation of the citizen to the nation as to cease to feel an interest in the issues which involve the vital interests of the entire nation. ${ }^{19}$

He went on to assure his supporters that as judge, he would be "blind to friend and foe" and would allow the "sword of the law" to "divide unswervingly, the right from the wrong, and be wielded by an unshrinking hand." 20

Tourgee was considered to have been a capable judge who strove for "faithful administration of the law." Accolades given by William A. Devin, chief justice of North Carolina's Superior Court in 1951, typify the opinions of other successive state attorneys and judicial figures in stating that:

With his background and temperament, with ideas in many respects foreign to those of the better element of the state, strange to say, Tourgee made an able and capable judge. He was not always dignified, but his work as a judge of law in the courts over which the presided stands out conspicuously in the judicial annals of that period. $^{21}$

Tourgee often gave speeches, and used pseudonyms such as Wenckar, a variation of his mother's maiden name, and Henry Churton to write numerous editorials and essays "denouncing the Negroes inferior status in the South and the intolerable activities of the Ku Klux Klan."22 This

\footnotetext{
19 Ibid.,31

20 Ibid.

21 Ibid.

22 Ibid., 32.
} 
outspokeness had a deleterious effect on his image, and in spite of his impressive record in reconstructing post-war North Carolina, his overt efforts to advance the state's black population decreased his popularity in the white community and made him a target of the Ku Klux Klan.$^{23}$

Undaunted by threats on his life, Tourgee attacked the Klan by writing a letter to North Carolina's Governor Holden in 1870. In it, he cited several lynchings which had occurred in the state. To Tourgee's disadvantage, the letter was published in the local newspaper, further putting his life and that of his family in danger. ${ }^{24}$

In 1874, Toinette, Tourgee's first novel, was published under the pseudonym "Henry Churton." In Toinette, Tourgee told the fictitional story of two slaveowners who developed intimate relationships with two mulatto slave women who happened to be mother and daughter. The story explored the psychological dilemma and social consequences of slave owners who fell in love with their enslaved mistresses. The publication of Toinette, which was "essentially a criticism of the South," encouraged Tourgee's continued writing of southern scenarios. ${ }^{25}$

Writing appears to have been a solice to Tourgee as the mid 1870 s

23 Dibble, Albion Tourgee, 43-44.

24 Ibid., 45.

25 Otto H. Olsen, Carpetbagger's Crusade: The Life of Albion Winegar Tourgee (Baltimore: John Hopkins Press, 1965), 213. 
heralded the return of political dominance by the Democrats. This favorable position for Democrats ensured the loss of Tourgee's judgeship and his defeat in the race for a congressional seat in 1874 . The Democratic hold was further stabilized during the state constitutional convention of 1875 , when several issues that were promoted by the Democrats were ratified in spite of Republican protest. As the prospect for Republicans pursuing political aspirations grew dimmer and as earning a living became more difficult, Tourgee resorted to private legal practice and, in 1876, briefly held the position of pension agent in Raleigh, North Carolina. ${ }^{26}$

As the Reconstruction era moved toward an end, Albion Tourgee began to believe that he and other Radical Republicans had been unrealistic in their goal of uniting blacks and whites in the South. His feelings were unabashedly revealed in the title of his book, A Fool's Errand by One of the Fools, which he wrote in 1879. The book is considered to have been the first detailed historical account of the Reconstruction period written by someone with firsthand knowledge of the era. Although it was written in novel form with fictitional characters, it was perceived as being autobiographical -- the experiences of Comfort Servosse, the main character, remarkably paralleling Tourgee's life and experiences. Included in A Fool's Errand are disturbing instances of lynchings and evolving KKK terroism which Tourgee began to protest from its beginnings. For example, the story is told of:

${ }^{26}$ Ibid.,191-208. 
Two white, and three colored men .. terribly beaten in this county on Wednesday night. On Friday two colored men were hanged. They were accused of arson; but there was not a particle of evidence of their guilt; indeed, quite the contrary; and they were men of good character, industrious, and respectful. ${ }^{27}$

After living in the South for fourteen years and playing a major role in reconstructing post war North Carolina, Tourgee, disheartened and discouraged, left the region in 1879. The initial move from Greensboro placed the him in Denver, Colorado, where he contracted for an editorial position on the Denver Evening Times. He also became sufficiently inspired by the "still-prevailing romance and excitement of the mining frontier," to invest moderately in real estate and mining. ${ }^{28}$ However, the success of A Fool's Errand motivated his move to the Northeast and directed his thoughts back to the problems of the South and his literary career, which had begun to blossom after the publication of A Fool's Errand (1879) and Bricks Without Straw (1880). By 1881, as noted by one of Tourgee's biographers, Otto Olsen, "Tourgee was at the pinnacle of his literary and political fame," and finally receiving substantial financial compensation for his writing. ${ }^{29}$

For a brief time during the early 1880 s, Tourgee and a friend were

\footnotetext{
27 Tourgee, Fool's Errand,193.

28 Olsen, Carpetbagger's Crusade, 223.

${ }^{29}$ Ibid., 245.
} 
partners in an unsuccessful journalistic venture -- editing and publishing the weekly magazine, Our Continent. Between 1884 and 1898, he worked as a contributing editor to the weekly Chicago Inter-Ocean, the newspaper to which Ida B. Wells sent reports of her travels while on the anti-lynching campaign in Scotland and England. Wells praised the Inter-Ocean's and Tourgee's liberalism in her autobiography by stating that "only the InterOcean of the dailies and Judge A. W. Tourgee as an individual, had given any systematic attention and discussion to the subject ... of lynching." 30

In 1888, Tourgee began writing the weekly series of Inter-Ocean articles entitled "A By-stander's Notes," in which he "frequently analyzed African American problems along with other topics such as education, politics, religion, civil service, defense of carpetbaggers and Republicans, and wearing the bloody shirt."31 Excerpts from "A By-stander's Notes," were occasionally reprinted in Anti-Caste and primarily related to unlawful violence against African Americans and the fact that whites were committing those crimes without penalty. It was of great concern to Tourgee that:

Only four white persons [had] been punished for the murder of a coloured citizen in the South in twenty-six years, though such killings averaged more than one a day during that time. No coloured citizen's

${ }^{30}$ Alfreda Duster, ed., Crusade For Justice: The Autobiography of Ida B. Wells (Chicago: University of Chicago Press, 1970), 156.

${ }^{31}$ Gross, Albion W. Tourgee, 116. 
right or coloured woman's honour has any legal protection or redress in one-third the territory of the Union. No coloured citizen of the United States dare defend his person, his home, his virtue, or his own right against the violence, lust, or greed of a white man. A mob may openly take the life of a citizen of the United States anywhere within the limits of any State of the Union without remedy of redress against the individuals who compose it or the State municipality which permits it. This is the only Christian nation, except Russia, of which such infamy can be predicted. ${ }^{32}$

Several examples of the atrocious killings were included in the article. One told the story of Edward Laurent, a prominent African American in Avoyelles, Louisianna, who was killed by a "band of Regulators" for helping a friend defend himself from a mob a week earlier. The same fate befell the minister who, in his sermon referred to the victim as a "worthy citizen," and encouraged his congregation to pray that "the time might come when law would rule and justice be done . . ."33

Tourgee believed during this time, that it was within the power of the government to remedy these societal ills by enforcing existing laws and protecting its citizens regardless of race. "Has the Government of the United States any right or power to protect the life of the American citizen on American soil ?" he asked. "Has it the power to guarantee to him the free exercise of his legal privileges?" 34

\footnotetext{
32 Albion Tourgee, "A By-stander's Notes," Anti-Caste, 5, no.9 (October, 1892): 2.

33 Ibid.

34 Ibid.
} 
The firm belief in the possibility of change and the desire to do something concrete motivated Tourgee's formation of the National Citizen's Rights Association (N.C.R.A.) in 1891. According to his biographer, Theodore Gross, establishing the organization "was an attempt to act rather than merely speak on behalf of the Negro."35 The philosophy of those supporting the association was based on the belief that a large number of American citizens would demand action in support of equal rights for blacks and that the government would have to take notice and address their issues. To potential members, Tourgee used the example of slavery and sectionalism as an analogy for emphasizing and illustrating the methodology of this new scenario and stated that:

We have yet in our memories an example fragrant with solemn warning. If three millions of American freemen had individually but unitedly, boldly, and persistently demanded the emancipation of the negro by lawful and peaceful methods in 1851, there would have been no need of the mustering of three millions of soldiers to put down the Slaveholders' Rebellion in $1861 .^{36}$

The principles of the N.C.R.A. were expounded upon by Frederick Douglass in an Anti-Caste article titled "New Anti-Slavery Movement in America: Judge Tougee's Citizen's Equal Rights Association." 37 The object

35 Gross, Albion W. Tourgee, 118.

36 Albion Tourgee, "America," Anti-Caste (excerpted from Tourgee's pamphlet, "Is Liberty Worth Preserving?") 5, no.4 (April, 1892): 1-2.

37 The N.C.R.A was sometimes referred to as the National Citizen's Equal Rights Association. 
of the organization was to procure for all citizens:

First, equal rights, equal opportunity, and equal protection of the law; Second, secure the fullest protection of the rights of free speech, and open public discussion, and the free exercise of the elective franchise by all legal voters, without fear of peril to person or estate from any source whatsoever; Third, secure the enactment and enforcement of just and equal laws, and to aid and encourage the legal assertion of all just rights and legal privileges of citizens; And fourth, to do whatever else may legally and peaceably be done to remedy unjust and oppressive conditions; and render the rights of American citizenship secure against assault, whether by legislative enactment or unlawful conspiracy, in every state in the Union. ${ }^{38}$

In noting that "ink is cheaper than blood; ballots a more civilized force than bullets; and the law a nobler weapon than the sword,"39 Tourgee expressed the value of non-violent action and advocated a political solution to African American concerns as had T. Thomas Fortune in his organization of the Afro-American League. Securing enfranchisement privileges and encouraging a strong political constituency among African Americans were viewed by most civil rights agitators of that period as the fait accompli of the anti-lynching and anti-discrimination movements. ${ }^{40}$

38 Frederick Douglass, "New Anti-slavery Movement: Judge Tourgee's Citizen's Equal Rights Association," Anti-Caste 5, no. 2\&3 (February and March, 1892): 1\&2.

39 Albion Tourgee, "America," Anti-Caste 5, no.4 (April, 1892): 2.

40 For insight into the political ideologies of African American agitators of the late nineteenth and early twentieth centuries see Ida B. Wells' "How Enfranchisement Stops Lynching" originally appearing in Original Rights Magazine, reprinted in Mildred Thompson's Ida B. Wells-Barnett: An Exploratory Study of An American Black Woman, 1893-1931, (Brooklyn: Carlson Publishing, Inc.,1990). Also see August Meier's Negro Thought in America, 1880-1915, (Ann Arbor: The University of Michigan, 1968); and Black Leaders of the Nineteeth Century, edited by John Hope Franklin and August Meir, 
The initial call for members of the N.C.R.A. was issued through the Chicago Inter-Ocean in October 1891. Apparently, interest in the Association was overwhelming with "ten thousand persons, residing in 42 states" enrolling within the first few weeks. Since no fee was required, membership hinged primarily on one's signature as proof of the individual's adherence to the goals and principles of the organization. ${ }^{41}$ The acquisition of two million signatures represented the number which Tourgee felt would be impossible for the government to ignore. To follow this initial phase, Tourgee espoused a mass movement on the part of the organization to educate the public on the principles of liberty and citizenship, but acknowledged that that aspect of the organization's duties awaited funding for postage and printing. It appears also that the positive response that the organization initially generated was tempered by a significant number of difficulties alluded to by Catherine Impey, who told her subscribers that:

The difficulties confronting the association are enormous. Apathy or opposition from, say three-fourths of the North -intense hostility from the whole white South, with very few exceptions. Even while we were staying at the Tourgee's home, a negro lay in a Southern jail for merely collecting names for the roll of members. ${ }^{42}$

(Urbana: The University of Illinois Press,1982).

41 Tourgee, "America," Anti-Caste, 2.

${ }^{42}$ Catherine Impey, "America Re-visited," Anti-Caste 5, no. 4 (October, 1892): 3. 
According to Frederick Douglass, "a large proportion of those who were first to join this new crusade [were] soldiers of the war of Rebellion" whom Tourgee believed were attracted to the cause "because they [knew] how much it costs to remedy a fundamental error ... that blood and tears [were] the inevitable price of justice ... that the denial of one citizen's rights is a menace to the rights of all." 43 Numerous memberships were received from a variety of persons, black and white, but what appears to have encouraged Tourgee most in his effort to promote the N.C.R.A. was the "moving and revealing response " of southern blacks. Their letters and endorsement of the organization "bared the horrors and sufferings" of their lives in the South and "revealed their sensitivity to a sad and terrible fate."44

The impact of the N.C.R.A. was moderate. Tourgee capitalized on the organization's strength in numbers to promote anti-discrimination legislation and supportive politicians. What was considered a significant accomplishment of the organization occurred in 1892, when the General Conference of the Methodist Episcopal church "approved a strong resolution denouncing prejudice and segregation and calling for remedial action by churches, the press, and all levels of government." Also in that same year, as a result of pressure exerted by Tourgee and the N.C.R.A., the Presbyterian General Assembly denounced crimes against African Americans. ${ }^{45}$ Of the

43 Ibid., 2.

${ }^{44}$ Olsen, Carpetbagger's Crusade, 314. 
more "fruitful" of the organization's involvments was its struggle against lynching. Olsen notes that "from the very first the N.C.R.A. had joined this crusade with proposals for a Federal law establishing local liability for such a crime. $" 46$

In June 1891, Tourgee was appointed attorney in a case designed to test the constitutionality of the state of Louisianna Separate Car Act of 1890. This was the case of Plessy v. Ferguson which was repeatedly appealed until 1896 when the "separate but equal" law was legalized by a decision of the United States Supreme Court. As an N.C.R.A. attorney, Tourgee argued unconvincingly that Plessy's citizenship rights under the Fourteenth Amendment had been infringed upon, and that "enforced segregation ... is a form of slave-like caste," which violated the Thirteenth Amendment. None of Tourgee's arguments against discrimination prevailed, and as has been witnessed by history, Plessy v Ferguson served to justify racial segregation for more than fifty years. ${ }^{47}$ However, the tactic of pressing court cases aimed at "establishing the point that segregation equals discrimination" represents a precedent set by the N.C.R.A. -- "a tactic which was later used extensivly by the NAACP."48

\footnotetext{
45 Ibid., 321.

46 Ibid., 325

${ }^{47}$ Ibid., 326-331.

48 Donald Grant, The Anti-Lynching Movement, 1883-1932 (San Francisco: R. E. Research Associates, 1975), 33.
} 
During the summer of 1890, Tourgee's Inter-Ocean articles included advice to T. Thomas Fortune's Afro-American League, which by this time had become a "fairly active organization." His concern was that the efforts of the League might be thwarted by opponents of the cause and suggested that it "should be a secret affair in order that it might escape persecution in the South."49 Tourgee did not take his own advice, however, when establishing the N.C.R.A., which did become a target of those who opposed the advancement of African Americans in the North and South. ${ }^{50}$

Tourgee did not go abroad during the time period covered in this chapter. Later, after the turn of the century, he did become a resident of France as a result of becoming the United States Consul in Bordeaux. His contact and relationship with citizens of the United Kingdom, however, are evidenced by the Anti-Caste articles, visits from Catherine Impey, his association with those who were also sought out by Impey and others in the British humanitarian efforts, as well as correspondences associated with this transAtlantic group.

Tourgee demonstrated his concern about African American problems during the Civil War when he refused to surrender a black man who had saved his company. He appears to have genuinely expected the South to be

${ }^{49}$ Dibble, Albion Tourgee, 111.

${ }^{50}$ Catherine Impey, "America Revisited," Anti-Caste, 3. 
thoroughly reconstructed when he relocated to North Carolina. His observations and experiences in the South strengthened his conviction to democratic ideals of equality with respect to African Americans. As attorney, judge, and a member of the Republican Party, he used his legal skills and political connections to encourage legislation that would improve African American conditions. Tourgee's anti-lynching activities relate to his exposure of and protest of lynchings in his correspondences, his books, his editorials in the Inter-Ocean and other newspapers and journals, and his formation of the N.C.R.A. He used the novelistic approach to writing, particularly in A Fool's Errand and Bricks Without Straw, to vent his frustration over what he perceived as the failure of Reconstruction, which included non-enforcement of laws meant to protect African Americans from violence. His writing also served as a form of protest about the dire state of affairs that African Americans had fallen into. He was one of the first to reveal lynching atrocites and other post-emancipation injustices to northern readers, and his exposure of those injustices placed him in the forefront of the initial stages of anti-lynching protest in America and abroad. 


\section{CHAPTER FOUR}

\section{Anti-Caste}

The verbal and written protestations against lynchings made by Frederick Douglass, T. Thomas Fortune, Albion Tourgee and others in the 1880s found an expanded, multi-national audience in the readership of the journal, Anti-Caste. Publication having begun in March 1888, the English periodical became a means of disseminating information about lynchings and other forms of racial discrimination in America during the anti-lynching movement's earliest stage. Anti-Caste is the primary source of evidence that reveals a cooperative effort between the English sympathizer, Catherine Impey, and Americans associated with anti-lynching protest prior to Ida B. Wells' involvement in the movement. Through Anti-Caste, non-Americans became aware of the abuses inflicted on the African American community and the efforts that were being made to address them.

The centralizing force behind English participation in the nineteenth century anti-lynching campaign was Catherine Impey. Through the agency of her journal Anti-Caste, Impey provided a platform for American writers and activists to inform the international community of lynchings in America. 
It was Impey who initiated the movement which would eventually involve other members of the religious and humanitarian communities. In 1883, she encouraged Frederick Douglass to send " a deputation of coloured Americans" to visit England for the purpose of telling their story. "The fact is," she stated, "that we in England know next to nothing about you since the [Civil] War."1 The publication of Anti-Caste would soon change that.

Launched in England in March of 1888, Anti-Caste became a primary vehicle for disseminating information relative to the many expressions of discrimination toward people of color in various areas of the global community. By 1888, Impey had visited the United States several times, and through the press and conversations with friends and acquaintances, had acquired a comprehensive picture of the workings of "colour caste" in America.

The readers of Anti-Caste became acutely aware of segregation in America, systematic political disfranchisement, economic depression and unequal opportunity in the black community, perpetuation of the myth of African inferiority, and how lynching had emerged as the tactic of choice in

${ }^{1}$ Catherine Impey to Frederick Douglass, 15 February 1883 DLC Frederick Douglass Collection, General Correspondence R3 V5 Fr689-697, Manuscript Division, Library of Congress. 
promoting the white American agenda.

The format of the monthly publication included Impey's editorials, articles written specifically for Anti-Caste, and reprinted pieces from other American or English periodicals. Sometimes poetry or quotations were used to further emphasize or show sentiment to a particular aspect of "colourcaste." Most articles were in support of the cause; however, occasional unfavorable responses to the journal's mission appeared in certain issues. Impey had been somewhat inspired in the design of the journal by the example of The Southern Letter, a periodical edited and published by Booker T. Washington. Acknowledging that inspiration, Impey wrote Washington a letter in which she noted that while the "shape and style" of Washington's model was appealing to her, she felt that Anti-Caste was unique in its message and readership. Admitting that she was not sure if she had written him before, she felt as if she had "known him for years" having heard so much about him and his "successful work." Some years prior, someone had sent Impey:

A little parcel of The Southern Letter and it at once opened my eyes to the possibility of Anti-Caste. For years I had tried to get a good paper set on foot on this question but suppose the risk of expense and the tax on my time made it impossible I should myself attempt it and yet no one else was saying what I wanted said - or not saying it to the people I felt it should reach. Your paper was an inspir- 
ation to me. I found the cost of printing would be very inconsiderable - I tried to get my English printers to make mine just like yours in shape and style. All I can say is Anti-Caste became a living reality. It is most encouraging to find how far it reaches. It stirs up newspaper correspondence - brings letters from your Gen. Armstrong - from the democratic press \&c. into our English papers. May God bless it to the good of your people and mine. ${ }^{2}$

In a postscript to the letter, Impey told Washington that she was sending a copy of the letter "to [her] white friends in America. Those of them who as yet have not responed to the repeated sending of the little paper."3

In her autobiography, Ida B. Wells-Barnett described Anti-Caste as "a magazine published in England in behalf of the natives of India."4 However, while it was dedicated to alleviating the global oppression of people of color, such as the Australian Aborigines, East Indians, Africans, and South and Central Americans, it focused primarily on the African American problem. Its mission statement clearly expressed the journal's purpose: "To give insight into the evils of caste as it prevails in countries where white races habitually ostracize those who are even partially

\footnotetext{
2 Catherine Impey to Booker T. Washington, 5 March 1890, in Louis Harlan, ed., The Booker T. Washington Papers, Vol. 3, 1889-1895 (Urbana: University of Illinois Press, 1974), 33.

3 Ibid.

${ }^{4}$ Alfreda Duster, ed., Crusade For Justice: The Autobiography of Ida B. Wells (Chicago: University of Chicago Press, 1970), 82.
} 
descended from darker races." 5

To disseminate information that would reveal the realities of such oppressive conditions, Impey enlisted the assistance of "personal friends and acquaintances" in America and the United Kingdom. These were people with whom she had visited or corresponded, from whom she had received information and encouragement, and were supporting the anticaste movement by contributing articles and becoming subscribers and distributors.

The following supporters, were listed in the first issue of Anti-Caste in 1888:

Frederick Douglass, Ex U. S. Marshall of District of Columbia.

Rev. Benjamin T. Tanner, ed. of A.M.E. Church Review.

Rev. B. F. Lee, ed. Christian Recorder (official organ of A. M. E. Church).

Rev. H. Frederick \& wife, Sierra Leon Missionary A. M. E. Church.

Rev. Jas. M. Townsend, Travelling sec. of Foreign Missions of do.

Bishops Daniel A. Payne, Jas. A. Shorter, J. M. Brown, (\& family), of do.

The late Bishops J. P. Campbell, H. M. Turner, and R. H. Cain.

5 Catherine Impey, "To Our Readers," Anti-Caste, 1, no. 1 (March 1888): 1. 
Bishops J.J. Moore, \& J. Hood \& wife \&c., of A. M. E. Church.

Rev. J. C. Price, N. Carolina.

John C. Dancy, ed. Star of Zion, organ of A. M. E. Church.

Rev. E. W. S. Peck, Maryland.

Rev. E. M. Pinckney, S. Carolina.

Mrs. Amanda Smith.

The late Dr. H. H. Garnett of N. York \& W. Wells Brown, Boston.

T. Thomas Fortune, ed. New York Age.

T. McCants Stewart, New York, Ex U.S. Consul to Liberia.

Rev. W. B. Derrick \& wife, Sullivan St. Church, New York.

Prof. J. P. Joseph, New York.

Prof. J. P. Shorter, A.M. of Wilberforce University.

Mrs. F. Jackson Coppin, Pres. of Institute of Coloured Youth, Philadelphia.

Mrs. Frances Harper, National Supt. of Coloured work of the WCTU

William Still and family (including his daughter, Mrs. D. Anderson), Philadelphia.

Rev. Shafter, Mr. Robt. Purvis, and many others of same city.

Miss Gardner of Boston, Mr. \& Mrs. Lewis Haydn, also the editors of the Boston Advertiser, \&c, \&c. ${ }^{6}$

${ }^{6}$ Ibid. 
A primary concern of the editor of Anti-Caste was making the journal affordable to everyone desirous of reading it. The fee per issue, aimed at covering the cost of postage, remained minimal throughout the duration of publication. The cost of a single copy was one pence. Subscription terms were one shilling per year, or five copies for two shillings and 6 pence per year.

There were special terms for larger quantities, and to encourage a wider distribution, an extra free copy was given to all subscribers of 1 shilling or more. Subscriptions could be paid with money orders, cash, or American, English, or Colonial postage stamps. In addition, a percentage of each issue was distributed free of cost to "teachers of Day or Sunday Schools, Adult Sunday Scholars, Members of Christian or Philanthropic organizations, or any thoughtful class of readers, rich or poor."7

Within three months of publication, Anti-Caste had acquired ninety-two subscribers who donated various subscription amounts. While there were several subscribers in the United States, most of the names and locations indicated that the majority lived in the United Kingdom. Donations noted in

\footnotetext{
${ }^{7}$ Catherine Impey, Anti-Caste, (Every issue): 4.
} 
pounds, shillings, and pence, showed generous contributions exceeding the required fee of one pence. ${ }^{8}$

The currently accepted historiography on the anti-lynching movement gives the impression that Catherine Impey became aware of American lynchings in 1892, when she first met Ida B. Wells and heard her condemnation of the crime. One is led to believe that this realization moved Impey to begin a campaign for heightening the awareness of those outside of America to the atrocities. It is true that Impey was motivated to become even more involved in her social reform activites after meeting Wells, but her knowledge of lynchings in America and the impulse to help eliminate them obviously predated the initial meeting between the two women.

Information about lynchings in America began to appear in Anti-Caste from its inception. The very first issue reprinted T. Thomas Fortune's article from the New York Age entitled "The Proposed Afro-American League," in which abolishing lynchings was stated as a primary purpose of the League. References to mob violence appeared regulary, and there were several articles supporting Fortune's Afro-American League and acknowledging its potential as a solution to mob violence, lynchings, and

\footnotetext{
${ }^{8}$ Catherine Impey, "Subscriptions Received," Anti-Caste, 1, no. 3 (May 1888): 4.
} 
other African American concerns.

Throughout Anti-Caste's first year of publication, references to lynchings in America appeared in most issues. The June 1888 issue contained the article "White Men Not Hung in Georgia," which compared and decried the treatment of African American men in Georgia to that of white men. The author assailed the American judicial system for allowing whites the privilege of a trial by jury which assured their innocence when accused of crimes against blacks, but failed to uphold the law when blacks were accused or even suspected of crimes. Disturbed by the acquittal of "a gang of ruffians" who had obviously committed and gotten away with such crimes, the complainant noted that:

Out of a hundred and twenty murders committed in that bloody country in the past thirteen years, the majority of them by white men, not one has resulted in the conviction and hanging of the criminal. But coloured men are not allowed the luxury of a trial in Edgefield. Whenever one is suspected of a crime, he is forthwith swung up to a tree until he is dead, and this by the best people. ${ }^{9}$

In July of 1888, Anti-Caste carried a brief article about the death of Reverend W. H. Gatin, pastor of an A. M. E. Church of Starkville,

\footnotetext{
9 "White Men Not Hung in Georgia," New York Freeman, reprinted in Anti-Caste, 1, no. 5 (June 1888):1.
} 
Mississippi. Reverend Gatin had been shot (reason unknown) by officers of the town attempting to arrest him. Noting the unlawful character of the arrest, the writer remarked that the "fiends in garb of officers of the law found it more agreeable to their taste to kill the unfortunate man than to execute the warrant. Reverend Gatin was a peaceable citizen and a man of excellent reputation."10

An article titled "Abridgement of the Negroe's Liberties in Texas," likened the reluctance of blacks to "endorse by voice and vote, the principles of prohibitionists," to their experiences with prohibition. The author stated that "the Negro had been tasting the bitter fruit of prohibition ever since he was stolen from his fatherland beyond the sea." That they had been prohibited from all civil liberties, as well as being "prohibited by mob violence from having a fair trial before the law. . . "11

In May 1888, Rev. B. M. Taylor of Kansas contributed the article "Samples of Southern Outrages." Taylor was responding to an essay which had appeared in the Galveston News in February of 1888, telling how the South was "endeavoring to do the fair thing by colored people." Those "fair things" related primarily to educational opportunities. Taylor's response

10 Anti-Caste, 1 , no.6 (July 1888): 2.

11 "Abridgment of the Negroes Liberties In Texas," $\underline{\text { Anti-Caste, }}$ 1, no.2 (April 1888): 2. 
provided numerous examples of discrimination to prove that southern treatment of blacks had been anything but "fair." Lynchings and mob violence were predominant among the stated mal-treatments: ${ }^{12}$

I have known instances where colored men were arrested, put in prison, and taken out and lynched for petty crimes, for which white men would not be arrested... . In this town of Hempstead, about three years ago, white men shot Negroes down on the streets like dogs, and nothing was done about it. . . Another instance occurred at Brenham, just twenty miles above Hempstead, in which the white night mob took from jail by night three colored men and lynched them. At ex-Governor Ireland's home, Seguine, three men were taken from the jail and lynched without trial in open daylight, and nothing was done with the lynchers. ${ }^{13}$

Anti-Caste served as a consistent witness to African American concerns throughout 1888, and in January 1889, the beginning of the second year of publication, emphasis on those concerns remained strong, as is clear by Impey's remarks in that issue:

The Editress thanks the unknown sender of the Virginia Planet - a Southern Negro journal. Week by week this little paper registers the number of Negroes 'lynched,' i.e. snatched from the gaol [jail] or from the hands of justice and hung or shot by the impatient lawless white mob. ${ }^{14}$

12 B. M. Taylor, "Samples of Southern Outrages," Anti-Caste, 1, no.3 (May 1888): 2-3.

13 Ibid.

14 Catherine Impey, Anti-Caste, 2, no. 1 (January 1889): 2. 
The fact that Impey noted in that editorial that 165 victims had been lynched from "July 1887 to October, 1888," and that an excuse for one of the lynchings was, "marrying a white woman," is evidence that she was well aware of the prevalence of such crimes, and the irrationality of the reasons given for committing them. ${ }^{15}$

The following "letter from the editor," appeared in the March 1889 issue of Anti-Caste, and expressed Impey's disdain over the African American dilemma:

The sad cry from America is always sounding mournfully in my ears. The oppresive demands from the Southern master-caste sound ever more cruel. 'Disfranchise the negro - put him down - teach him to know his place,' seems to be the principal response to all his most worthy aspirations. Intimidation - lynching - terrorising - openly boasting of suppression of the negro vote ... ${ }^{16}$

A particularly lengthy August article, which culminated in a record of mob violence, told the story of African Americans in Louisianna who had established a new community near the village of Iberia and named it Freetown. The town prospered with "comfortable homes, a church, and a

15 Ibid.

16 Catherine Impey. This letter from the editor was, as many in Anti-Caste, untitled. They are identified by date, volume, and page number. Anti-Caste 2, no.3 (March 1889): 2. 
school-house," and the farmers "became quite forehanded, owning in some cases two or three hundred acres along the neighboring bayous." To economize, by offsetting the cost of cotton, a cotton gin was built by Simon and Livingston, two of the wealthier settlers of the town. That enabled the settlers to gin their own cotton and avoid taking it to the nearby town, where they believed "white neighbors charged too much for ginning." Such independence raised the ire of surrounding whites, who began to visit the "peaceful little hamlet" at night, in "lawless parties who styled themselves as Regulators." Although the twenty-five or so "able-bodied men in the settlement had organized under the Home Protection Society" and had attemped to protect their homes, the village was invaded, and "one third of ... the community was deliberately murdered."17

A December 1891 article titled "Lynchings in Mississippi" recounted the unfortunate demise of Mose Lemmons near Roebuck, Mississippi, who, because of his attempt to unite blacks in the area in avenging a previous lynching, was lynched himself. ${ }^{18}$

Occasionally Anti-Caste printed letters received from English people

17 "A Horrible Story," Anti-Caste, 2, no.8 (August 1889): 2. Reprinted from the New York Independent, 24 January 1889.

18 "Lynching in Mississippi," Anti-Caste, 5, no. 9 (September 1891): 2. A reprint from the New York Age, 27 December 1891. 
visiting or temporarily living in America. Those letters usually reiterated the state of affairs in America regarding injustice to African Americans and very often spoke of lynchings as well. In one particular letter, "Mrs. M. A. Marriage-Allen," was in Atlanta, Georgia, attending the American Association of Coloured Youth. She noted that she had had a very pleasant experience meeting and interacting with "influential coloured people ... and leading white people who are helping forward education amongst the coloured people here." She had visited several churches, schools, and colleges, and was quite impressed with what she had seen and heard. "I wish," she said, that "the people who talk of inferiority of the Negro could hear some of their papers and speeches, they would surely be astonished." 19 Judging from the letter, her experience could be likened to that of the abolitionists, for she noted that all white people engaged in the work, were "practically ostracized" in the southern states, which led them to associate only with others of like sentiment. The author of this letter of praise, ended the communication by stating that:

There have been two coloured people shot by whites here in the last few months, and nothing is done to bring them to punishment, and this is constantly occurring in

${ }^{19}$ M. A. Marriage-Allen, "An English Lady in Georgia, U.S.A." Anti-Caste, 4, no. 3 (March 1891): 3. 
the South. ${ }^{20}$

Another correspondence was from one of Impey's English friends who was living in the state of Alabama in 1890 . He had been "a tradesman in Devonshire County Town," but was led to become involved in "misssionary work among the coloured people." This Englishman preferred anonymity but wrote a lengthy letter describing his experience as a missionary, educating and ministering amongst African Americans. The message that he wanted to convey to English friends was that, due to restrictions placed on African Americans, slavery virtually still existed in America. Although "there is no auction block, no overseer and buckwhip," he stated, "the coloured people are slaves in every sense of the word." He noted that "caste prejudice was very strong," and that "whites were doing all they could to drive them out of the country." The letter concluded with this description of mob violence:

The lives of coloured people are not worth anything, as the case of Georgia State showed at Christmas last, when they butchered several in cold blood, and no attempt made to catch the white villains, but everything the coloured do is magnified to a 'rising' and 'rebellion,' so called to give the whites a pretext for revenge. We who seek to help them are treated as the scum of the earth. ${ }^{21}$

20 Ibid.

21 Anonymous letter from "An Englishman in Alabama." Reprinted in Anti-Caste, 3, no. 
One of the African Americans that Catherine Impey associated with and who encouraged and supported her inclination to assist African Americans in obtaining fair treatment in America was Fannie Jackson Coppin, principal of the Institute of Colored Youth in Philadelphia, Pennsylvania, and wife of Levi J. Coppin, a minister of the A.M.E. Church.

Fannie Jackson Coppin was born into slavery in the District of Columbia in 1837 and was freed while a young girl after an aunt saved $\$ 125.00$ and purchased her freedom. That freedom gave her the opportunity to go to New Bedford, Massachusetts, where she took up residence with another aunt, obtained a job, and began attending school. In 1851, at age 14, she went to Newport, Rhode Island, and worked as a servant for George Henry Calvert, great-grandson of Lord Baltimore and his wife, Mary Stuart. During that time, Mrs. Coppin was allowed to study piano, guitar, and academic subjects for one hour every other day. Thus having acquired an interest in education, she later attended Rhode Island State Normal School in 1859, and in 1861, enrolled at Oberlin College in Ohio. While at Oberlin, Mrs Coppin studied math, Greek, and French and voluntarily established an eveningschool for blacks who had migrated into the town during the Civil

2 (February, 1890):1 
War. In 1865, Coppin became one of the first African American graduates of Oberlin College and went on to teach at the Institute For Colored Youth, which later became Cheyney College. ${ }^{22}$

During the summer of 1888, Mrs. Coppin vacationed in England and used the trip as an opportunity to solicit funds for her school.

In the August 1888 issue of Anti-Caste it was noted that Mrs. Coppin "had been an important feature in ... anti-caste work during the past month." Coppin was described as being "a Christian lady in the fullest sense of the word, who has been giving much of her hard earned holiday to the cause of our coloured brethren in America."23

The following month, in a letter to Frederick Douglass, Catherine Impey mentioned Coppin's visit, noting that Coppin had been "spending some months in England" and that she "had really enjoyed her company." Coppin had evidently given a number of lectures related to the discrimination experienced by American blacks, especially in terms of education -- her particular line of work. Impey indicated that Coppin had

\footnotetext{
22 Ursula V. Battle, "Fannie Jackson Coppin: An Educator with a Lasting Legacy," On Line, http://www.btimes.com/blackhistory/3-6-98/coppin1.html, and Today from the Sun, Maryland's Online Community, http://www.sunspot.netfeatureslifestylebalto.memory10feb10.column?coll=bal-artslife-today.

23 Catherine Impey, Anti-Caste, 1, no. 6 (August 1888): 2.
} 
made a favorable impression and had generated "a great deal of sympathy for the difficulties against which coloured Americans have such a hard struggle." 24

I believe we should do well to follow this up - I wish there were a possibility of cooperating among those of us who care about having this wrong state of things righted. . . . your leading colored Americans ... Mrs Coppin's meetings and possibly Anti-Caste and other things combined seem already to have made an opening. ${ }^{25}$

Impey saw a window of opportunity in the response that Coppin had received and believed that it could lead to some unified effort between the work that she was doing with Anti-Caste and humanitarians in England working with leading African Americans.

Another person of African descent who had visited London and gave witness to African American atrocities was Bishop Walter Hawkins of Ontario, Canada, who was in London to speak at the annual meeting of the National Temperance League in 1891. The Anti-Caste article noting this described the setting and order of business at the meeting and then

24 Catherine Impey to Frederick Douglass, 4 September 1888, DLC Frederick Douglass Collection, General Correspondence R5V7 Fr076R-080, Manuscript Division, Library of Congress.

25 Ibid. 
proceeded summarize Hawkins' speech. While Hawkins, who had apparently lived in America prior to becoming a bishop of an A.M.E.

Church in Canada, acknowledged the many achievements that blacks had made since emancipation, he was quick to point out the difference in the treatment of blacks in Canada compared to their mistreatment in the United States, and to give examples of that mistreatment. He stated that :

Thousands ... had met with violent deaths during the last fifteen years. The hip pocket revolver is much to blame. Let a black man offend a white, and a bullet is through his brain before he can go six yards, and nobody takes any notice - it is quite an every day affair, nobody is punished, the prejudice against us is so strong. ${ }^{26}$

During the period of Reconstruction, the sharecrop system developed as a primary means of economic venture, which co-partnered landowners with newly freed African American laborers. Though the system had an unsteady beginning for planters, it soon evolved to a profitable replacement for the slavery era. Many former slaveholders weathered the destruction of the Civil War and soon became lucrative merchants and planters, while blacks fell victim to a never ending cycle of debt and peonage. The exploitative nature of the system ensured white economic hegemony, a status that

${ }^{26}$ Catherine Impey, "Reception to a coloured Bishop in London," Anti-Caste, 4, no. 4 (April 1891): 4. 
southern whites were eager to protect. ${ }^{27}$

Historian Nell Painter provides clear examples of the efforts that were made to discourage frustrated blacks from leaving the South and depleting a dependable labor force. She referred to the exodus of nearly 7,000 African Americans who migrated to Kansas in the late 1870s as "Exodusters." When those emigrants decided to seek land in Kansas, whites of the lower South, specifically Louisianna, Mississippi, Tennessee, and Texas, vigorously protested their absence in the southern labor pool. Painter noted that whites used such tactics as:

Violence, suing for breech of labor contracts, taking money and possessions from blacks so that they would have to reaccumulate them, hiring agents to persuade potential migrants to stay, and limiting their means of transportation and of acquiring necessities while waiting along the Mississippi River. ${ }^{28}$

The lengths to which white planters went to restrain black laborers and prevent the emigration of blacks from the southern states is exemplified in the Anti-Caste article entitled "Foully Murdered." The account of this story was sent to Catherine Impey via a news clipping from an American

27 Jack M. Bloom, Class, Race, And The Civil Rights Movement (Bloomington: Indiana University Press, 1987), 21.

${ }^{28}$ Nell Irvin Painter, The Exodusters (New York: Alfred A. Knopf, 1976), 87. 
newspaper. In recounting it, Impey wrote that "another of the uncivilized and barbarous southerners has reddened his hand with the blood of a coloured American. Hear the story as telegraphed from the scene in Arkansas last week."29 It appears that the planter, a resident of Louisianna, had boarded atrain to force a former black laborer to return to his plantation, where he had likely labored as a tenant farmer. The worker, determined to go to Oklahoma in search of a better existence, refused to return to the plantation and was shot and killed on the spot by the planter. ${ }^{30}$

Regularly appearing in Anti-Caste were references to author, George W. Cable. Cable had written several books advocating a revisionist southern philosophy regarding equal rights for African Americans. Anti-Caste readers were frequently encouraged to examine Cable's writings. The second issue of the journal mentioned his article "The Negro Question in the United States," which was published in the London Contemporary Review in March of 1888. Impey suggested that subscribers read the article and then lend it to others. She also reminisced about her visit with Cable while in America:

${ }^{29}$ Catherine Impey, "Foully Murdered," Anti-Caste, 4, no. 7 (July 1891): 1. ${ }^{30}$ Ibid. 
I shall not soon forget the long afternoon spent in earnest conversation with him on this anti-caste question at his picturesque home a year and a half ago. I am glad that by thus laying the case before us he makes an appeal to England. ${ }^{31}$

As is noted by the following Anti-Caste advertisement, many African

Americans had embraced Cable as a friend and supporter of the cause:

Mr. G. W. Cable, the novelist, speaks for the 'New South,' and for the negroes, for although he is a Southerner and a white man of slave-holding descent, his every utterance on this question is endorsed and emphasized by the negro community in general, and especially by their best writers and their press. ${ }^{32}$

George Washington Cable was revered by members of the African American community of the post-Reconstruction era in the same manner that Albion Tourgee was received. However, although Cable and Tourgee both suffered the wrath of white southerners for their advocation of equal rights for African Americans, they were perceived differently by southerners because of their heritage and background experiences. While Tourgee was labeled a carpetbagger due to his status of ex-Union soldier transplanted in the South; Cable, a native southerner was viewed as a traitor, intending to reform southern attitudes and equalize race relations. ${ }^{33}$ Cable's

31 Catherine Impey, "George W. Cable," Anti-Caste, 1, no. 2 (April 1888): 1.

32 Catherine Impey, Anti-Caste, 2, no. 3 (March 1889): 3. 
unpopularity in the South was alluded to by T. Thomas Fortune when he stated that:

One of the most unpopular men in the South today is Mr. George W. Cable, the successful novelist of Louisiana, who has in a spirit of the truest philanthropy lifted up his voice and dipped his pen in gall in denunciation of the civil and political outrages committed upon coloured Americans by his own people. ${ }^{34}$

At this point, Cable had moved from Louisiana where his opinions were becoming a severe handicap, and took up residence in Massachusetts, a state that Fortune referred to as "the home of Garrison, Phillips, Sumner, and others, who gave and spent their noble lives in the long and arduous, but successful warfare against the accursed infamy of chattel slavery." 35

Often compared to Mark Twain, William Dean Howells, and Henry James, Cable had become well recognized as a novelist and essayist in America and abroad after the Civil War. He had published the stories which

33 For biographical information on Cable and examples of his writings see: Arlin Turner, ed. The Negro Question: A Selection of Writings On Civil Rights in the South by George Washington Cable (Garden City: Double Day \& Company, 1958); John Cleman, George Washington Cable Revisited (New York: Twayne Publishers, Inc., 1996); Louis D. Rubin, George Washington Cable: The Life and Times of a Southern Heretic (New York: Pegasus, 1969); and Philip Butcher, George Washington Cable (New York: Twayne Publishers, Inc., 1962).

34 T. Thomas Fortune, "The Negro and American Politics," Anti- Caste, 1, no. 10 (December 1888): 3 .

35 Ibid. 
make up the volume Old Creole Days (1879), two novels, The Grandissimes, and Dr. Sevier (1880 and 1884, respectively), the novelette, Madam Delphine (1881), and the historical work, The Creoles of Louisianna (1884). Many of his essays appeared in newspapers, particularly the New Orleans Picayune, in which he had a column in the late 1870s. From 1885, Cable began to write and lecture extensively on southern American issues in regard to African American civil rights and the antebellum and postbellum relationships between blacks and whites in the South. ${ }^{36}$

Cable was born in New Orleans on October 12, 1844, to slave holding parents, and while growing up, was completely comfortable living under those circumstances. His family exhibited itself as staunch Confederates during the Civil War, and after New Orleans had fallen to the Union, they were among the few residents who "refused to take the oath of allegiance, preferring to declare themselves enemies of the United States." At the time, Cable, still a youth, accompanied his family to Mississippi, where he later enlisted in the Confederate Calvery. It was at that time that the experience of war, and "the turmoil of struggle for survival," prompted

\footnotetext{
36 Arlin Turner, The Negro Question: A Selection of Writings On Civil Rights in the South by George Washington Cable (Garden City: Double Day \& Company, 1958), ix.
} 
Cable to "re-think and revise attitudes which had been a part of his heritage." He began to show a humanitarian concern for others during this period which accelerated after the war ended. ${ }^{37}$

In the process of advocating equal rights for African Americans, Cable was forced to assess the social, economic, and political structure of southern society and did not hesitate to call into question inherited attitudes and established customs and institutions. While reducing all legal and Constitutional arguments to ethical and moral considerations, he sought to change the laws of the land to encompass fair and equal treatment for all citizens.

In spite of Cable's liberal image, he had an uneducated and inaccurate perspective of African culture, sometimes referring to the continent of Africa as a "debased society"and its inhabitants as "an inferior race." However, unlike most of his contemporaries, he relegated those perceived defamations to a lack of opportunity rather than to an inherent state and pushed for creating opportunities, particularly educational, that would change conditions and contribute to a more equal status between the races. ${ }^{38}$

\footnotetext{
37 Rubin, George W. Cable, 12.

38 Turner, The Negro Question, 139-140.
} 
To Cable, the institution of slavery not only hampered the ability of blacks to advance, but he believed that the superior attitudes of whites as slave masters severely crippled their ability to develop humane relationships with blacks. As a result, whites acquired what he called "outrageous vices" during slavery that became even more evident after emancipation. By 1870 , Cable had become completely convinced of the immorality of slavery and of slavery's profound impact on postbellum America. To him, those "outrageous vices" which white society exhibited during the post Reconstruction era were the result of its involvement in the institution of slavery. In his essay, "My Politics," he concluded:

The peculiar institution tended, when it was in force, to promote in us a certain spirit of command - of dictation - that made our wills seem to us nearly or quite as authoritative as the laws, and sometimes more so. We were a race of masters. We were dictators. The main thing to be kept in sight was the discipline of the plantation. Hence a most lamentable laxness of parental discipline; a similar laxness of that defensive discipline by which society lays down its conditions of membership; and, springing distinctly from these deficiencies, a group of outrageous vices: shameless hard drinking, the carrying of murderous weapons, murder, too, and lynching at its heels, the turning of state and county prisons into slave pens, the falsification of the ballot, night riding and whipping, and all the milder forms of political intolerance. ${ }^{39}$

In Cable's opinion, the vices of southern white society could be remedied

${ }^{39}$ Ibid., 22. 
by adhering to Christian principals which would alter white supremacist attitudes and grant African Americans the rights that they deserved as citizens. $^{40}$

As a white southerner, Cable acknowledged his role and that of other southern whites in the oppression of African Americans and became a crusader for creating a "new South." He considered himself a spokesman for the "silent South" and believed that there were others in the region who shared his sentiments but were reticent to speak. "Amidst it all," he states, "the South has been silent, but times change -- have changed. Where it has been silent it now should speak." ${ }^{41}$ Initially attacking the evolving system of segregation and the convict lease system, Cable began to move from being strictly a novelist to a controversial reformer. ${ }^{42}$

Cable's plea for integration extended to the Sumner Union League, when prior to becoming a member, he suggested that the organization "might do greater honour than they have yet done to the memory of Charles Sumner, by abolishing the colour-line for membership." After being elected a member and at the request of the club, he drafted a new constitution to

${ }^{40}$ Ibid.

${ }^{41}$ Ibid., 87.

42 Rubin, George W. Cable, 109. 
reflect that suggestion. The "Draft" of that constitution as presented in AntiCaste promoted the right of all adult males, regardless of race to have the privilege of becoming members of the Sumner Union League. ${ }^{43}$

Cable was deeply disturbed by the exploitative character of the convict lease system which involved "the practice of letting out public convicts to private lessees, to serve out their sentences under private management." In a portion of his essay entitled "The Freedman's Case In Equity," he included a section which provided an example of the system as it was carried out in South Carolina and Georgia, showing a glaring difference of black and white prisoners in relationship to their populations within the two states. Even more alarming to Cable was the disproportionate number of pardons granted to black and white prisoners. "If this be a dark record," he stated, "what shall we say of the records of lynch law? But for them there is not room here." 44

The African American historian George Washington Williams provides

\footnotetext{
43 Catherine Impey, "Mr. Grady's New South," Anti-Caste, 2, no. 10 (October 1889): 1. The title of the article is a reference to Henry W. Grady, of the Atlanta Constitution, who advocated a "New South," based on industry and the development of the South's natural resources. Cable challenged Grady's racial views in the article by writing a derogatory poem, which he read at a Sumner Union League meeting.

${ }^{44}$ Rubin, George W. Cable, 78.
} 
an example of how some African Americans felt about Cable. In November

1888, Williams, inspired by Cable's writing and support of black

liberation, expressed a desire to make his acquaintance in the following

letter:

I have been one of your most ardent friends for many years; and in my History of Reconstruction of the Insurgent States have declared you to be the best conscience of the South; the John the Baptist of a new dispensation of good works and good will between the races and sections of our common country so long estranged. I should be pleased to grasp your hand and tell you how deeply I am indebted to you for the noble service done to the race to which I am in part bound by the ties of consanquinity. To continue in your good work is to secure a place in history next to Lincoln and Garrison. ${ }^{45}$

Williams and Cable eventually met and became friends. They corresponded frequently with each other, and Williams even joined the Open Letter Club, an organization which Cable had started to attract others who were sympathetic to his cause. Members were encouraged to write articles on southern issues relative to reforming the South and granting equality to blacks. Cable's account of Williams' willingness to join the club was noted in this diary entree of January 8,1889 :

Last night I read in Worcester. G. W. Williams met me at the station and took me to his pretty rooms at Hotel Adams to chat ... Williams is a mulatto, a Christian, a scholar, a man

45 Philip Butcher, "George Washington Cable and George Washington Williams: An Abortive Collaboration," The Journal of Negro History Lii, no. 4 (October 1968): 336. Note: Williams' History of Reconstruction of the Insurgent States was never published. 
of affairs, polished, graceful, laborious in life, author by profession, \& actually making his way in white society. He is writing now the History of Reconstruction. He is a strong addition to the Open Letter Club. ${ }^{46}$

Williams, the author of History of the Negro Race in America, 16191880, and History of the Negro Troops in the War of the Rebellion, 18611865 , rose to international prominence as a result of those publications, his nomination for minister to Haiti, and his outspokeness on the cruelty of King Leopold's policies in the Congo, about which he delivered an address to the World Federation of Missions in London in the early 1890 s. ${ }^{47}$

It is clear that by promoting Cable's writings, Catherine Impey saw in them solutions to African American problems. Cable's suggestions for a new South, T. Thomas Fortune's Afro-American League, and Albion Tourgee's Citizen's Equal Rights Association each represented avenues for quelling the rising tide of lynchings and racial discrimination. Therefore, Anti-Caste served as a vehicle for exposing the crimes and injustices to its readers as well as presenting the case for possible alternatives.

Periodically, Impey published a "Supplement" to the regular issue of Anti-Caste. A January 1890 "Supplement" noted the growth of the journal

46 Ibid., 139.

${ }^{47}$ Ibid. Also see John Hope Franklin, George Washington Williams: A Biography (Chicago: The University of Chicago Press, 1985). 
and gave credit to several people for "supplying the editor with newspaper notices, pamphlets, and magazine articles bearing on the caste question."48 Some of the individuals that Impey acknowledged as having fulfilled that service were:

Mrs. Francis Power Cobb Hon. Frederick Douglass, U. S. Minister of Haiti

Miss S. D. Collett, London

Mrs. Edmond Sturge, Pres., Birmingham Negro's Friends Society

Pandit S. N. Sastri, Calcutta

Mr. W. E. A. Axon, Manchester

Mr. J. Stuart, Isle of Wight Express

Francis W. Newman, Emeritus Prof., Oxford

Dr. J. E. Rankin, American Missionary Association

Prof. Scarborough, Wilberforce University, Ohio

Prof. Crogman, Clark University, Atlanta, Georgia

Bishop Tanner, A. M. E. Church of America

Mr. W. F. Mackenzie, British Guiana

Rev. H. M. Joseph, Antiqua

In addition to individual persons, English newspapers such as the

Liverpool Daily Post and the Manchester Guardian were also given praise

by Impey for advertising Anti-Caste in their papers. Editors of American

newspapers and magazines who had regularly sent articles and information

to Impey were thanked as well. Among them were: The Virginia Planet, the

48 Catherine Impey, "The Editor's New Year's Eve Address: Report of Progress, \&c." Anti-Caste, Supplement, 3, no. 1 (January 1890): 1. 
A. M. E. Church Review, the Philadelphia Sentinel, and the A. M. E.

Missionary Record. In London, the editors of the Anti-Slavery Reporter, and Our Forest Children, in Canada, and the Indian Messenger, in Calcutta, were mentioned. ${ }^{49}$

The supplementary issues of Anti-Caste tended to focus on growth and acceptance of the journal. Always included were remarks from subscribers who obviously inspired Impey to continue. Especially during the early stage of the anti-lynching campaign, she, as editor of Anti-Caste, was the primary instigator. Her supporters recognized that, as is evidenced by this letter from an English subscriber:

We are very glad of the increasing interest manifested in your work, which must help you a little in what must be arduous at times, comparatively single-handed as you are in it. I so think many of us who have inherited right views on this question of slavery still need much enlightenment as to the cruel disabilities under which our coloured brothers and sisters labour, and am so glad you feel this your special mission. ${ }^{50}$

Throughout the publication of Anti-Caste, Impey received similar words of encouragement from English subscribers, and friends and supporters of the work in which she had become engaged.

${ }^{49}$ Ibid.

${ }^{50}$ Ibid., 4. 
American contacts were as appreciative of this expose of American problems and assistance coming from England. Numerous Americans sent letters of praise and encouragement to Impey from which she often used excerpts in issues of Anti-Caste. Professor William S. Scarborough of Wilberforce University in Ohio wrote that "all said about the Negroes of this country is absolutely true." He expressed his belief that the "little journal [would] doubtless do much good towards awakening a sentiment against the outrages committed in the United States against the coloured people. ${ }^{51}$

From the January 1891 "Supplement" to the journal, Impey made a distinction between white and black American subscribers by listing them separately, noting that among the whites, "General Samuel Armstrong, founder of Hampton Institute in Virginia, Judge Albion Tourgee, author of Bricks Without Srtraw, Anna Gardner, one of New England's early abolitionists, Elizabeth Comstock, friend of the Kansas refugees, and Rev. C. S. Schaeffer, of missionary fame in West Virginia," had all written letters of praise for the work that she was doing with Anti-Caste. ${ }^{52}$ Quotes from letters written by "Dr. Nathan Mossell, a physician, and professor William L.

${ }^{51}$ Ibid.

52 Catherine Impey, "Editor's New Year's Address, Report of Progress, \&c." Anti-Caste, Supplement (January 1891): 1. 
Bulkley, of Clafflin University in South Carolina were included among the blacks who had written. Frances E. W. Harper, noted African American poet and activist in the anti-slavery and Temperance movements, acknowledged Impey as her "friend and sister" and wished her "health, love and strength" with which to "fight the battle." 53

Letters written by Frederick Douglass were frequently excerpted in AntiCaste. In January of 1890, Douglass, who noted that he "received AntiCaste regularly," inspired Impey with the following remarks:

There is a world wide need of your little witness against the pride and prejudice that poison the relations of human beings . . .Anything you can do to expose this foul spirit [of caste] and enlighten the moral sentiment of your countrymen on this subject excites our gratitude and increases our hopes of a better future. ${ }^{54}$

In that same issue of Anti-Caste another or Douglass' letters was quoted in which he expressed his gratitude for "at least one soul. . . willing to make a life warfare against this dark spirit." He wrote that "he had hope that [the] little journal, so faithful and true to the spirit of Universal Brotherhood [would ] raise up for itself many friends and suporters." 55 Anti-Caste was

53 Ibid.

${ }^{54}$ Ibid.

55 Ibid.,3. 
replete with such remarks from American and English supporters throughout its years of publication.

Anti-Caste provided an avenue of promotion for at least three other humanitarian organizations: The British \& Foreign Anti-Slavery Society, the Aborigines Protection Society, and the National Indian Association. Each submitted articles and advertised regularly in the journal. The British \& Foreign Anti-Slavery Society, located in London, supported "endeavors to put a stop to the horrors of the slave trade by all moral and pacific means." A fee of ten shillings constituted membership in the organization and entitlement to its publications. The Aborigines Protection Society was established in 1817 for the purpose of disseminating "accurate" information on the "rights and interests of native races." The primary focus of this organization appears to have been speaking out against the oppression of indigenous people in British colonies. The Aborigines Protection Society often made direct appeals to the Imperial Government on behalf of the injured and oppressed, and also promoted discussions on these issues in Parliament and the press. The National Indian Association, founded in 1871, extended to all members the Indian Magazine, as well as information on "grants to educational enterprises, \&etc." It also encouraged and extended the employment of medical women in India, gave aid and advice 
to Indians in England, and "promoted social intercourse between [the] English and Indians." 56

Impey encouraged her readers to further inform themselves about discriminatory practices in America by reading related literature. To this end, each issue of Anti-Caste included a book list by "popular American authors, illustrating the condition of the Freedmen since the War of the union." The books most often advertised were: Bricks Without Straw, and A Fools Errand by Albion Tourgee; Tiger Lily and Other Tales by Julia Thaxter; The Life of Frederick Douglass by Frederick Douglass; Life on a Georgian Plantation by Fanny Kemble; Reminiscences of an Abolitionist by Levi Coffin; Uncle Tom's Cabin and Dred: A Tale of Dismal Swamp by Harriet Beecher Stowe. Later issues contained references to Ida B. WellsBarnett's A Red Record.

Anti-Caste was published consistently between March 1888 and April 1893. In July 1893, Fraternity replaced Anti-Caste as the SRBM organ and disseminator of anti-lynching literature. Anti-Caste resumed publication in January 1895 but appears to have folded after the July issue of that

\footnotetext{
56 See any issue of Anti-Caste for references to these organizations. Articles related to their causes can be found throughout the various volumes.
} 
year. The life of the journal was brief, but it served the purpose that its editor intended; bringing attention to the severe oppression of African Americans and other oppressed people throughout the global community. The early stages of this English journal represent the initial unfolding of information relative to anti-lynching / anti-discrimination activity in America prior to the 1890s. The letters and editorials that were written by Frederick Douglass, T. Thomas Fortune, Albion Tourgee and others exposed African American oppression such as lynchings to people outside of the United States. Those revelations in the late 1880 s paved the way in 1893 , for the appearance in the United Kingdom of the movement's most recognized crusader, Ida $\mathrm{B}$. Wells. 


\section{CHAPTER FIVE}

\section{A Quickening of the Movement: Enter Ida B. Wells}

Wells campaigned energetically for truth and justice throughout her life, with anti-lynching activities figuring prominently among causes to which she gave her attention. The activities between May 21, 1892... and September 1, 1900, however, mark the most intense portion of her contributions to the anti-lynching movement. ${ }^{1}$

The diligent efforts of $\mathrm{T}$. Thomas Fortune, the Afro-American League, Frederick Douglass, Catherine Impey and her journal, Anti-Caste, Albion Tourgee and others laid a foundation for addressing American lynchings through lectures and journalism during the period of the 1880s. However, it cannot be said that the roles that they played superseded that of Ida B.

Wells. Wells' entrance into the scenario in 1892 was at a time when lynchings had increased significantly, making them a primary concern in the African American community. Wells had already gained the respect of many editors and had endeared herself to their readership as a contributing editor in numerous journals. What increased her magnetism and catapulted her into prominence, however, was the fact that she had had a peripheral experience with a particular lynching in Memphis, Tennessee,

\footnotetext{
${ }^{1}$ Jacqueline Jones Royster, Southern Horrors and Other Writings: The Anti-Lynching Campaign of Ida B. Wells, 1892-1900 (Boston: Bedford Books, 1997), 2.
} 
which placed her in the position of having been personally victimized by the perpetrators. That experience led her to begin investigating and exposing lynching atrocities in America, which added a new dimension to addressing the crime. Although there were innovations to the movement when Wells came aboard, those innovations were part of a continuum of activities related to abolishing lynchings. That they were effective, casts Wells-Barnett in the role of catalyst to the cause.

Historical accounts of the anti-lynching movement often depict Ida B. Wells-Barnett as the initiator of the movement. Usually, the efforts of her precursors in America and England are left out of those accounts. For example, in Wells-Barnett's autobiography, the editor, Alfreda Duster stated:

The most remarkable thing about Ida B. Wells is not that she fought lynching and other forms of barbarism, it is rather that she fought a lonely and singlehanded fight with the single-mindedness of a crusader, long before men or women of any race entered the arena. ${ }^{2}$

More recently, in DeCosta-Willis' The Memphis Diary of Ida B. Wells, a similar statement was made in the book's "Forward" which was written by

${ }^{2}$ Alfreda Duster, ed., Crusade For Justice: The Autobiography of Ida B. Wells (Chicago: University of Chicago Press, 1970), xxxii. 
Mary Helen Washington, who noted that, although DeCosta-Willis focused on the private world of Wells-Barnett's diary, the world at large knew her as a "one-woman crusade against lynching." Although we can see that the

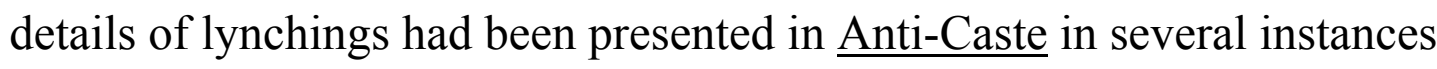
during the late 1880s, John Hope Franklin stated that Wells-Barnett "was perhaps the first person to recite the horrors of lynching in lurid detail."4

That even Ida B. Wells-Barnett perceived her involvement in the antilynching movement as catalytic-- one that introduced change, is evidenced by this remark:

The student of American sociology will find the year, 1894 marked by a pronounced awakening of the public conscience to a system of anarchy and outlawry which had grown during a series of ten years to be so common that scenes of universal brutality failed to have any visible effect upon the human sentiments of the people of our land. ${ }^{5}$

Here, Wells-Barnett was referring to the impact of trans-Atlantic sentiment which was generated by the publication in 1892 of Southern Horrors, her first pamphlet on lynchings, and her lecture tours in England and Scotland. Both activities had the effect of heightening public awareness of the crime in

\footnotetext{
${ }^{3}$ Miriam DeCosta-Willis, The Memphis Diary of Ida B. Wells (Boston: Beacon Press, 1995), xi.

${ }^{4}$ Duster, Crusade For Justice, ix.

${ }^{5}$ Ida B. Wells, A Red Record (Chicago: Ida B. Wells, 1895), 1.
} 
America, which was crucial to the mobilization of the anti-lynching campaign.

When Ida Belle Wells was born on July 16, 1862, in Holly Springs, Mississippi, the Civil War was well on its way. President Lincoln was desperately "seeking to hold the political middle ground," while he sought a way to begin the process of freeing enslaved Africans, without "alienating conservatives and southern Unionists." ${ }^{\prime 6}$ The proposal for gradual emancipation had been presented to the border states, while northern African American leaders were being urged to support the colonization of freedmen in Haiti or other Central American countries. ${ }^{7}$

For forty years, the American Colonization Society had encouraged the emigration of blacks to Africa as a means of solving the race problem. Directed at the free black population because they were viewed as "the main source of slave insurrections...[and] characterized as...a degraded people," colonization elsewhere, seemed the solution to a virulent problem. ${ }^{8}$ When

\footnotetext{
${ }^{6}$ Eric Foner, Reconstruction: America's Unfinished Revolution, 1863-1877 (New York: Harper \& Row, 1988), 6.

${ }^{7}$ Ibid.

${ }^{8}$ Amos Jones Beyan, "The American Colonization Society and the Formation of Political, Economic and Religious Institutions in Liberia, 1822-1900" (Ph.D diss., West Virginia University, 1985), 3.
} 
the war commenced, "the colonization chimera gained new popularity among conservatives who foresaw the inevitability of emancipation but dreaded its social consequences." A formal recommendation, urging Congress to assist financially in such a move, was made on December 3, 1861, by President Lincoln. However, by that time, many potential candidates for colonization had been encouraged to stay in the country by the passing of the "Confiscation" and the "Militia" Acts, which aided in freeing fugitive slaves and allowing them to participate in the war effort. ${ }^{10}$ In Mississippi, as in other regions of the American South, the Confederacy was initiating the process of impressment, which forced slaves, usually against their wishes and those of their owners, to serve in the Confederate Army. By the fall of 1862 "the labor shortage was so acute in the South that most states had authorized the impressment of slaves."11 The fall of Vicksburg and Port Hudson to the Union Army in July 1863 brought

Beyan's study, while providing a historical analysis of the political, economic, and religious realms of Liberian history, also includes significant background information on the American Colonization Society and the motivations of its founders.

${ }^{9}$ James McPherson, The Negro's Civil War: How American Blacks Felt and Acted During the War of the Union (New York: Ballentine Books, 1991), 79.

See the chapter entitled "The issue of Colonization" for a detailed discussion of the emigration ideologies of President Lincoln, northern and southern whites, and blacks during the Civil War.

${ }^{10}$ Ibid.

${ }^{11}$ John Hope Franklin and Alfred A. Moss, Jr., From Slavery To Freedom: A History of African Americans, $7^{\text {th }}$ ed. (New York: McGraw Hill, Inc., 1994), 212. 
the inevitable destruction of the Confederacy in Mississippi. Those events, along with the poor condition of the state, desertion of Confederate troops into Union lines and the desire of citizens to resume a normal life, forced the surrender of Mississippi in August 1863. ${ }^{12}$

Holley Springs, in 1862, was the county seat of Marshall County, Mississippi. The population in Marshall County in 1860 was recorded as 29,000, of which 17,439 were enslaved blacks and 1,295 were slave owners. As whites were in the minority, maintaining slavery in the region was paramount to maintaining white control. As such, "Marshall County played an integral role in Mississippi's march toward secession" by providing more signatures on the secession ordinance than any other county. ${ }^{13}$ With a majority of blacks throughout Mississippi, fear of insurrection hung heavy among whites. Motivated by that anxiety, violence toward blacks escalated during the Civil War as evidenced by the lynching of forty blacks in Natchez the year prior to Wells-Barnett's birth. ${ }^{14}$

During the Civil War, Holley Springs exchanged hands between Union and Confederate armies at least fifty-nine times, but did not

\footnotetext{
${ }^{12}$ Foner, Reconstruction: America’s Unfinished Revolution, 199.

${ }^{13}$ Linda O. McMurry, To Keep the Waters Troubled: The Life of Ida B. Wells (New York: Oxford University Press, 1998), 5.

${ }^{14}$ Ibid., 6.
} 
experience many skirmishes until the latter months of 1862. Along with the rest of the state, Holley Springs sustained significant damage during the last stages of Mississippi's involvement in the war. In preparation for the Vicksburg battle, Union General Ulysses S. Grant had moved troops into northern Mississippi just outside of Holley Springs. The temporary headquarters was fully equipped with military paraphernalia, food, and other materials, which filled local churches, the Masonic Temple, public buildings, and some private homes. Experiencing a heightened sense of security, slaves in the area began to run away from plantations to Union camps to such an extent that Grant appointed Chaplain John Eaton to set up a "contraband" camp to accommodate them. Eaton noted that "the slaves came garbed in rags or silk, with feet shod or bleeding, individually or in families and larger groups -- an army of slaves and fugitives." 15

The temptation to join the fugitives must have been strong for most enslaved persons presented with the opportunity to do so. However, the urge was resisted by the Wells family and many others who chose to stay in Holley Springs. That may not have been as difficult of a decision for Jim Wells, Ida's father, as it was for some. He was raised on a plantation in Tippah County, Mississippi, where he had had a somewhat privileged

${ }^{15}$ Ibid., 7. 
existence during enslavement. Being the son of the slave "master," he was allowed to learn a trade, and at the time of Ida's birth in 1862 , had been apprenticed as a carpenter to the Bolling family in Holley Springs. ${ }^{16}$

Throughout Jim Wells' childhood, his experience as an enslaved person living under the care and tutelage of his white father had been a less extreme existence than that of most enslaved Africans. While apprenticing at the Bolling home, he committed himself in marriage to Elizabeth Warrenton, the Bolling's cook. Elizabeth's experience during enslavement had been much harsher than Jim's. Born into a family of ten children on a plantation in Virginia, she and two sisters had since been repeatedly sold and physically abused. The futility of her efforts to locate family members after the war was an experience that was reiterated by scores of freed men and women. ${ }^{17}$

When the war ended and slaves were emancipated in 1865, Jim and Elizabeth Wells, as many freed men and women, adjusted their lives to the dictates of living in a free society. Although they considered themselves married, they legalized their union. Jim used his skills as a carpenter to provide for his family, and he also became very active in Reconstruction era

\footnotetext{
${ }^{16}$ Duster, Crusade For Justice, 8 .

${ }^{17}$ Ibid.
} 
politics. Ida grew up during this period of Reconstruction (1866-1877), a time of hope for newly freed blacks who witnessed their inclusion into politics and the policy making machinery of the southern region, and the passing of Constitutional amendments that legally defined their freedom, citizenship, and enfranchisement. The beginning of stability and selfsufficiency was also characterized by the visibility of black troops in many areas, the ability to go to school, and the possibility of acquiring land via the promise of forty acres and a mule.

Due to its large percentage of African American citizens, Mississippi elected a significant number of black politicians on the state and local level during the Reconstruction period. There were forty African American members present at the 1870 state legislative meeting in Jackson, which represented 33 percent of the legislative body. That percentage remained fairly consistent throughout the era. ${ }^{18}$ Mississippi was the only state to send two African American senators to the United States Congress -- Hiram Revels and Blanche K. Bruce. Revels was living in Holley Springs at the time of his election to the Senate and is remembered for his honesty and

\footnotetext{
${ }^{18}$ W. E. B. DuBois, Black Reconstruction in America (Cleveland: World Publishing Company, 1935), 440.
} 
conciliatory attitude. ${ }^{19}$ Bruce would later become a staunch rival of WellsBarnett because of remarks made by her in 1891, accusing him of abandoning African American interests for personal advancement. ${ }^{20}$

Jim Wells supported the Republican Party, as did the large majority of African Americans. Since he was often away from home attending political meetings, it is very possible that he was a member of the Loyal League, the all-black political organization that sought to increase the black constituency of the Republican Party. There was a branch of the Loyal League in Holley Springs that had been established by A. C. McDonald, a founder of Shaw University, and Nelson Gill of the Freedmen's Bureau. Being especially resentful of black participation in the League, members of the Ku Klux Klan hid under Gill's house one night listening to the proceedings of their meeting and waiting for the appropriate moment to shoot Gill, but the attempt was thwarted by another Klansman having second thoughts. ${ }^{21}$ Wells-Barnett wrote of how fearful her mother became whenever those political meetings were held at night, and Jim was late coming home -- an increased source of

\footnotetext{
${ }^{19}$ McMurry, To Keep the Waters Troubled, 11.

${ }^{20}$ Ibid., 232.

${ }^{21}$ Ibid., 10.
} 
concern after vigilanteeism began to use force to discourage the political involvement of blacks. ${ }^{22}$

Obtaining an education was high on the list of priorities for newly freed blacks. Recognizing the connection between education and upward mobility, Jim and Elizabeth Wells wanted their children to obtain as much education as possible and adhered to the concept by sending them to Shaw University, the local school established by the Freedmen's Aid Society. Shaw University (later Rust College) offered courses ranging from elementary education to normal school training for teachers. It was established by northern missionaries, who had come to the area during Reconstruction to help educate newly freed blacks. Motivated by her desire to learn to read, Elizabeth Wells even went to school along with the children while Jim Wells served as a trustee of the school. ${ }^{23}$

Wells was very much influenced during her upbringing by the teachings of her parents. From them, she gained a deep sense of justice and a belief in humanity's ability to solve its problems. Guided by the religious and spiritual example of her mother, who encouraged the reading of the Bible and who took them to church and Sunday School regularly, she

\footnotetext{
${ }^{22}$ Duster, Crusade For Justice, 9.

${ }^{23}$ Ibid.
} 
acquired a model to emulate and principles which guided her and formed the basis for many of her ideals. Her father, to whom she was very attached, instilled intellectual aspirations, and political and civic training. One of her earliest recollections was of reading the newspaper to her father and some of his friends as they admired her ability to do so. ${ }^{24}$

Overcoming the hardship of losing both parents and a sibling to the yellow fever epidemic, which hit Holley Springs and the surrounding area in 1878, was undoubtedly the most tragic episode in Wells' young life. As can be imagined, it was an extremely difficult experience and quite a dilemma for sixteen-year-old Ida to face. Jim Wells had been a member of the Masons, and adhering to their pledge to aid fellow Masons and their families in times of need, members of the organization offered to handle the situation by placing the children under the guardianship of specific members.

Realizing that her parents would have been devastated by the separation of their children, Ida insisted on dropping out of school, finding employment, and keeping her family together. ${ }^{25}$

Having completed enough schooling to take the examination to become a teacher, Wells pursued that course as a possible occupation. On
${ }^{24}$ Ibid.
${ }^{25}$ Ibid., 15-20. 
passing the exam, she began teaching in a rural community, six miles outside of Holley Springs. For three years, she kept up the grueling schedule of teaching school during the week while her grandmother and other family members and friends watched the small children. On weekends, she returned home to cook, wash clothes, and clean for her siblings in preparation for the week to come. ${ }^{26}$

In 1881, Wells left Holley Springs and went to Memphis to teach, and that is where she encountered her first major race-related conflict. In May of 1884, while riding the train to work, the conductor asked her to move from the "ladies car" where she was sitting to the "smoker" where Negroes were expected to sit. She had purchased a first class ticket, and segregation had not yet become a legal reality; therefore, she believed that she had the right to sit where she pleased. When the conductor saw that she was not going to move voluntarily, he proceeded to forcibly remove her from the train, at which time she braced her feet against the seat in front of her and clenched her teeth into his fist, making his efforts somewhat more difficult. The conductor however, was soon aided by other railroad employees -- all of

\footnotetext{
${ }^{26}$ Ibid.
} 
whom were cheered on by the white passengers in that section, and since she was overpowered and the train was coming to a stop, she did get off. ${ }^{27}$

Frustrated, but undaunted, she went directly to the office of an attorney and filed a suit against the C\&O Railroad and initially won that suit, receiving $\$ 500.00$ for damages. To Wells' dismay however, the $\mathrm{C} \& \mathrm{O}$ appealed the case to the state Supreme Court, and the verdict was eventually overturned in the railroad's favor. ${ }^{28}$ Wells expressed her extreme disappointment over the ultimate outcome in her diary:

I firmly believed all along that the law was on our side and would, when appealed to, give us justice. I feel shorn of that belief and utterly discouraged, and just now, if it were possible, would gather my race in my arms and fly away with them. ${ }^{29}$

Wells' writings during the decade of the 1880 s reveal her hopefulness for newly emancipated black America. Her interests and concerns were illuminated in her editorials and the diary that she kept while living in Memphis during the latter half of the 1880 s. At a time when certain "AfroAmerican agitators" had already begun to speak out against the national crime of lynching, Wells was more involved in improving her teaching skills

\footnotetext{
${ }^{27}$ Duster, Crusade For Justice, 18.

${ }^{28}$ For documents pertaining to this case, see the Ida B. Wells Papers, Special Collections, Reggenstein Library, University of Chicago.

${ }^{29}$ DeCosta-Willis, The Memphis Diary of Ida B. Wells, 140.
} 
and addressing the inadequacies of the school system and churches of her community, as well as questioning her abilities and development as a female and human being. These were her early journalistic years -- a time when she was just breaking into the field and was not quite sure of her footing. She wrote on a variety of issues, from articles related to racial uplift, which often criticized the disunity and inaction of members of the black community, to emphasizing the African American female's experience in the refined world of black Memphis and her role in the late Victorian 1800s. ${ }^{30}$

The article, entitled "Functions of Leadership," which Wells wrote for the Living Way in September 1885, chastised so-called African American leaders for neglecting to use their influence and affluence to help those less fortunate. The article is reprinted here in its entirety:

\section{Functions of Leadership}

I came across a letter last week in the Detroit Plain Dealer, from Washington, signed S. S. R., in which he gave a whole string of names, of men who are famous as orators, politicians, officeholders, teachers, lawyers, congressmen, and an ex-senator - from whom to choose a leader or leaders of the race. "Let me see" mused I, "these men have acquired fame and wealth in their several callings, they have and are now declaring themselves devoted to the interest of people, and are thereby looked upon as leaders, have impeachable characters, are justly called representa-

\footnotetext{
${ }^{30}$ The interests and activities of Wells-Barnett during the 1880s are recorded in her autobiography, Crusade For Justice: The Autobiography of Ida B. Wells, and in her diary, annotated and edited by Miriam De Costa-Willis, and published as The Memphis Diary of Ida B. Wells.
} 
tive of the race - but since they have by individual energy, gotten the well earned laurels of fame, wealth, individual recognition and influence - how many of them are exerting their talents and wealth for the benefit or amelioration of the condition of the masses? I look around among those I know, and read up the histories of those I do not know, and it seems to me the interest ceases after self has been provided for. Of those who are amassing, or have wealth I cannot call to mind a single one who has expended or laid out any of his capital for the purpose of opening business establishments, or backing those that are opened by those of limited means; none of them have opened such establishments where the young colored men and women who have been educated can find employment, and yet complain that there is no opening for the young people.

The whites have the young people of their own race to employ, and it is hardly to be wondered at that they do not do for the Negro what his leaders have not done for him; if those who have capital to employ in establishing such enterprises as are needed why - the - the leaders are leaving a great field, whereby their leadership can be strengthened, undeveloped. The ambition seems to be to get all they can for their own use, and the rest may shift for themselves; some of them do not wish, after getting wealth for themselves, to be longer identified with the people to whom they owe their political preferment; if no more. They are able to pay for berths and seats in Pullman cars, and consequently can report that - "railroad officials don't bother me, in traveling," and give entertainments that have but a single preservation from such, can look and listen unmoved saying, "if it were my wife or daughter or relative I would do so and so," so what real benefit are they to their race any way? "Their example is beneficial, by inspiring others to follow in their footsteps with a hope of similar success," did someone say? True, I had almost forgotten that: example is a great thing, but all of us cannot be millionaires, orators, lawyers, doctors; what then must become of the mediocrity, the middle and lower classes that are found in all races? It is easier to say, "Go thou and do likewise," than do it. I would like very much for S. S. R. to tell me what material benefit is a "leader" if he does not, to some extent, devote his time, talent and wealth to the alleviation of the poverty and misery, and elevation of his people? ${ }^{31}$ 
Though often a generalization, similar accusations of African American leadership have been reiterated by others since those early postemancipation years. Historian Carter G. Woodson, for example, also encouraged educated blacks to reach back into the community and extend an opportunity to someone and also take advantage of readily available talent. ${ }^{32}$

Wells often defended the character of African American women in her editorials. African American females, who were sometimes accused of being sexually promiscuous and of loose morals and character, began in the latter part of the nineteenth century to speak out against the allegations. Another historian concluded that these female focused articles indicate that Wells "subscribed to the concept of womanhood, which undergirded the racial uplift movement, spearheaded in the 1880 s and 1890 s by 'Race' women such as Anna Julia Cooper, Mary Church Terrell, Fannie Jackson Coppin, Josephine St. Pierre Ruffin, and others. ${ }^{, 33}$ Wells also believed that women occupied a special position in society, as indicated by her essay

\footnotetext{
${ }^{31}$ Iola, "Functions of Leadership," Living Way (12 September 1885). Prior to exile from Memphis, and before starting her anti-lynching efforts Ida B. Wells-Barnett wrote under the pseudonym, Iola. This essay was reprinted first in the New York Age, and more recently in Miriam DeCosta-Willis' The Memphis Diary of Ida B. Wells, 178.

${ }^{32}$ Carter G. Woodson, The Mis-education of the Negro (Washington, D. C.: Associated Publishers, Inc., 1969), 111-119.

${ }^{33}$ DeCosta-Willis, The Memphis Diary of Ida B. Wells, 188.
} 
entitled “A Woman's Mission," which emphasized the value of women's

influence and the role of African American women in the late nineteenth

century. She asked:

What is, or should be woman? Not merely a bundle of flesh and bones, nor a fashion plate, a frivolous inanity, a soulless doll, a heartless coquette -- but a strong, bright presence, thoroughly imbued with a sense of her mission on earth and a desire to fill it; an earnest, soulful being, laboring to fit herself for life's duties and burdens, and bearing them faithfully when they do come; but a womanly woman for all that, upholding the banner and striving for the goal of pure, bright womanhood through all vicissitudes and temptations. Her influence is boundless. Only the ages of eternity will serve to show the results of woman's influence. ... The masses of the women of our race have not awakened to a true sense of the responsibilities that devolve on them, of the influence they exert; they have not yet realized the necessity for erecting a standard of earnest, thoughtful, pure, noble womanhood, rather than one of fashion, idleness and uselessness. $^{34}$

The model woman, as Wells perceived her in the late 1880s, and described her in the article, "The Model Woman: A Pen Picture of the

Typical Southern Girl," which she wrote for the New York Freeman was:

not without refinement....not coarse and rude in her manners, or loud and fast in her deportment. Nor is the stiff, formal, haughty girl the ideal. The field is too broad and the work too great. The typical girl's only wealth is her character; and her first consideration is to preserve that character in spot-

${ }^{34}$ Iola, "Woman's Mission, "New York Freedman, 26 December 1885. Reprinted in Miriam DeCosta-Willis, The Memphis Diary of Ida B. Wells, 179. 


$$
\text { less purity. }{ }^{35}
$$

The examples of Wells' writings in the 1880s reveal the range of topics which consumed much of her interest. Although she was concerned about the evolving prevalence of lynchings and the unjust practice of lynchlaw, she had not yet begun to address it journalistically. There are several indications in her diary of leanings toward confrontationism. As DeCostaWillis noted, the diary "predicted the fearless and outspoken crusader against lynchings and segregation whom Wells would become." ${ }^{36}$ However, in the 1880s, she was an African American female in her twenties, whose militancy was on the horizon -- smoldering embers, not yet bursting into flames.

\section{The Memphis Lynching and the Demise of Iola}

Wells was forced to move closer to being an African American agitator and re-evaluating some of her previous assumptions, when, in 1892, her close friend, Thomas Moss, and his business partners, Henry Stewart, and Calvin McDowell were brutally lynched. Up to that point, Wells, although advocating the intervention of the judicial system in African

\footnotetext{
${ }^{35}$ Iola, "The Model Woman: A Pen Picture of The Typical Southern Girl," New York Freeman 18 February 1888. Reprinted by Miriam DeCosta-Willis in The Memphis Diary of Ida B. Wells, 187.

${ }^{36}$ DeCosta-Willis, Memphis Diary of Ida B. Wells, xiii.
} 
American crimes which had led to lynchings, had leaned toward believing that such horrendous acts had been provoked by the accusations of rape as reported by the perpetrators. Moss, Stewart, and McDowell, however, had not committed any such crimes. Their guilt lay in the pursuance of a new business venture, "The People's Grocery," which was established in a location that placed it directly across the street from the store of W. H. Barrett, a white competitor. ${ }^{37}$

Wells' reaction to the Memphis lynchings was the beginning of her role as catalyst of the nascent anti-lynching movement. From that point, anti-lynching editorials began to predominate in her journalism. The first examples of that journalism began in Memphis just after the lynchings, as Wells encouraged the African American community of Memphis to emigrate to the Midwest. Black migrants had begun to settle in the Midwest as a result of post-Reconstruction economic, political, and social hardships. She advised blacks to save their money and leave a town where they could expect no protection of their lives or property and where a fair trial in the courts was impossible when accused by whites. ${ }^{38}$ African Americans responded by leaving in mass. Historian Patricia A. Schecter estimates that,

${ }^{37}$ McMurry, To Keep the Waters Troubled, 130.

${ }^{38}$ Duster, Crusade For Justice, 52. 
within months, over 4,000 blacks left Memphis. ${ }^{39}$ Most went to Oklahoma and Kansas, a move that had a deleterious effect on the white businesses of the town. By 1892, a significant number of African Americans seeking improved living conditions had emigrated from the South to the Midwest. In Tennessee, Benjamin “Pap" Singleton had vehemently espoused African American migration to Kansas. Wells, as a journalist, would have certainly been aware of the "exodus" of blacks who had begun to settle in that region. $^{40}$ The African American community of Memphis also followed the suggestion of Wells to boycott the city streetcars, leading the operators of the system to ask for her input in encouraging them to resume riding the transit system. She instead told the the boycotters to "keep up the good work." ${ }^{41}$

As Wells began to realize the inaccuracy of allegations of rape of white women, her opinions were reflected in her editorials:

Eight Negroes lynched since last issue of the "Free Speech" one at Little Rock, Ark., last Saturday morning where the citizens broke (?) into the penitentiary and got their man; three near Anniston, Ala., one near New Orleans; and three at Clarksville, Ga., the last three for killing a white man, and five on the same old racket-

${ }^{39}$ Patricia A. Schechter, Ida B. Wells-Barnett \& American Reform, 1880-1930, (Chapel Hill: The University of North Carolina Press, 2001), 78.

${ }^{40}$ For details of the Kansas exoduster movement, see: Nell Irvin Painter, Exodusters: Black Migration To Kansas After Reconstruction (New York: Alfred A. Knopf, 1976).

${ }^{41}$ Duster, Crusade For Justice, 55. 
the new alarm about raping white women. The same program of hanging, then shooting bullets into the lifeless bodies was carried out to the letter.

Nobody in this section of the country believes the old thread bare lie that Negro men rape white women. If Southern white men are not careful, they will over-reach themselves and public sentiment will have a reaction; a conclusion will be reached which will be very damaging to the moral reputation of their women. ${ }^{42}$

White response to the editorial can be summed up by an emphatic reply, which immediately appeared in The Daily Commercial of May 25, 1892:

Those negroes who are attempting to make the lynching of individuals of their race a means for arousing the worst passions of their kind are playing with a dangerous sentiment. The Negroes may as well understand that there is no mercy for the Negro rapist and little patience with his defenders. A Negro organ printed in this city, in a recent issue publishes the following atrocious paragraph... ${ }^{43}$

Of course, the "atrocious paragraph" was Wells' above stated editorial. Similar reactions were editorials in other local white papers as well. The Evening Scimitar, believing the author of the article to be a man, went so far as to issue in graphic detail, the following warning:

\footnotetext{
${ }^{42}$ Ida B. Wells-Barnett, On Lynchings: Southern Horrors, A Red Record, Mob Rule in New Orleans (Salem: Ayer Company, Publishers, Inc., 1993) 4. This is a reprint in its entirety of Southern Horrors, A Red Record, and Mob Rule in New Orleans, three pamphlets authored by Ida B. Wells between 1892 and 1900. They were reprinted from manuscript collections at Howard University Library.

${ }^{43}$ Ibid., 4 .
} 
If Negroes themselves do not apply the remedy without delay it will be the duty of those whom he has attacked to tie the wretch who utters these calumnies to a stake at the intersection of Main and Madison Sts., brand him in the forehead with a hot iron and perform upon him a surgical operation with a pair of tailor's shears. ${ }^{44}$

There were repeated editorials about the African American's alleged propensity to sexually assault white women in the local white journals.

Wells gave particular attention to the lengths that the white press went to dehumanize African American males and justify lynchings in "The Malicious And Untruthful White Press," a chapter in her pamphlet, Southern Horrors. Such outspokeness by an African American woman during the 1890s, a period totally unsupportive of female and African American assertiveness, exemplifies Wells' courage and conviction relative to justice and equality. Wells' investigative nature was peaked when she realized the futility of expecting unbiased reporting by the white press in regard to lynching. She knew that African Americans had to become involved in telling their own story and begin to state the facts of lynching incidents.

"The press," she proclaimed:

contains unreliable and doctored reports of lynchings, and one of the most necessary things for the race to do is to get the facts before the public. The people must know before they can act, and there is no edu-

\footnotetext{
${ }^{44}$ Ibid., 5.
} 
cator to compare with the press... The Afro-American papers are the only ones which will print the truth, and they lack means to employ agents and detectives to get at the facts. The race must rally a mighty host to the support of their journals, and thus enable them to do much in the way of investigation. ${ }^{45}$

Northern as well as southern white newspapers, as Wells noted, were usually biased in their reports of lynchings. Reports of lynchings in the New York Times, for example, often gave the impression that victims had brought the crime upon themselves, by emphasizing alleged black criminality and failing to admonish the lynchers for appointing themselves judge and jury. ${ }^{46}$

Wells believed that public reaction to lynchings should show an abhorrence of the crime by moving to bring "the strong arm of the law" upon the lynchers and delivering to them, swift and severe punishment. She urged blacks to arm themselves for protection and to strike back by boycotting white businesses, noting that:

The appeals made to the white man's pocket has been more effectual than all the appeals ever made to his conscience. Nothing, absolutely nothing, is to be gained by a further sacrifice of manhood and self respect. By the right exercise of his power as the industrial factor of the South, the Afro-American can demand and secure his rights, the punishment of lyn-

${ }^{45}$ Ibid., 23.

${ }^{46}$ See "Lynching At Duluth," New York Times 7 May 1893; Hung On A Hickory Tree, New York Times 11 May 1893; and other examples of the New York Times for this time period. 
chers, and a fair trial for accused rapists. ${ }^{47}$

Wells, after the Memphis lynching of Moss, McDowell and Stewart, had, through her editorials, played a major role in encouraging the emigration of hundreds of African Americans from Memphis and the successful boycott by blacks of the city's transit system. However, the white backlash that was created by her editorials, which brought into question the excuses given for lynchings, was severe enough to force Wells' exile from the South. After learning that a committee of whites had met and placed a price on her life to hasten her capture, she found it prudent to leave the region permanently. That action launched her into the forefront of anti-lynching agitation. ${ }^{48}$

Where she had only occasionally come in contact with other African American agitators such as Frederick Douglass and T. Thomas Fortune, she was now part of that circle of African American movers and shakers. The black women's club movement was on the brink of unfolding when Wells appeared in New York as a new correspondent for the New York Age. Enthralled by her story and touched by her predicament, she was befriended by Maritcha Lyons and Victoria Earl Mathews, who had heard of her plight and wanted to make others aware of it. Lyons, a school teacher and a writer,

\footnotetext{
${ }^{47}$ Wells-Barnett, On Lynchings, 23.

${ }^{48}$ Ibid., 19.
} 
was one of the first African American females to be named assistant principal of a Brooklyn public school. Mathews was a journalist with the

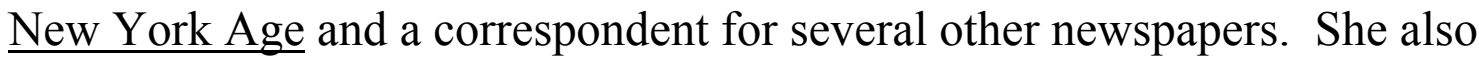
founded the White Rose Mission, a settlement house for African American female emigrants from the South. Both women were social reformers, experienced in community uplift work. ${ }^{49}$

Lyons and Mathews called together the women of New York and Brooklyn and planned a testimonial fundraising event, with Wells billed as the key-note speaker. The event, which took place on October 5, 1892, at New York's Lyric Hall, was “well planned and executed." The black press provided free advertisement, and the organizers, the Ida B. Wells Testimonial Reception Committee, spent over $\$ 150.00$ toward making the event a memorable occasion. Inside Lyric Hall:

Gas jets spelled out "Iola" at the back of the stage, and programs were printed on miniature copies of the Free Speech. The ushers and committee members wore white silk badges lettered with 'Iola'. Floral arrangements included a horn of plenty donated by the ushers. ${ }^{50}$

Two hundred and fifty women from New York, Philadelphia, Boston, and other northeastern cities attended the gathering and listened to Wells'

\footnotetext{
${ }^{49}$ Royster, Southern Horrors and Other Writings, 23.

${ }^{50}$ McMurry, To Keep the Waters Troubled, 171; Duster, Crusade For Justice, 79; Detroit Plaindealer, 1 October 1892.
} 
heartfelt and vivid depiction of the Memphis lynchings and the response of southern whites that had caused her exile. In a show of sympathy, support, and recognition, the women presented Wells with a gift of a gold brooch in the shape of a pen, a symbol of her profession, and $\$ 500.00$ to help restart her newspaper. Wells used the money instead to publish $\underline{\text { Southern Horrors, }}$ an extension of the article which she had written describing the Memphis incident. $^{51}$

It was at that meeting also that African Americans who were inclined to organize were so inspired by their exhibition of unity and their recognition of the need to make an impact in their communities, they determined to come together in groups and work for the betterment of the race. Through that effort, the first African American women's clubs of the post-emancipation era were born. For example, Lyons and Mathews immediately established the Women's Loyal Union in New York, ${ }^{52}$ and Josephine St. Pierre Ruffin, a journalist involved in charitable work in Boston, was inspired to expand her efforts with the Women's Era Club.

\footnotetext{
${ }^{51}$ Duster, Crusade For Justice, 77-82.

52 The Women's Loyal Union was organized on Dec. 5, 1892. See A History of the Club Movement Among the Colored Women of the United States of America, As Contained in the Minutes of the Conventions Held in Boston July 29, 30, 31, 1895 and the National Federation of Afro-American Women, Held in Washington, D. C., July 20, 21, 22, 1896; Ida B. Wells Papers, Special Collections, Reggenstein Library, University of Chicago.
} 
African American women, especially in the North, had long been involved in club work associated with church auxiliaries, and educational, political, and cultural activities since the antebellum era. They had also organized to work with the abolitionist and suffrage movements. However, the 1890s black women's club movement was spurred on by new challenges such as lynchings and a desire by the elite female representatives of the race to establish an impeccable image in that society. ${ }^{53}$

By 1890 , a sizable and significant black middle class was developing in the country, and women of that group heeded the call to serve in the improvement and uplift of their race and communities. In addition to Ida B. Wells, Maritcha Lyons, Victoria Earl Mathews, and Josephine St. Pierre Ruffin, other examples could be seen in the work of Fannie Barrier Williams of Chicago; Josephine Silone-Yates of Kansas City, Missouri; Mary Church Terrell, Helen A. Cook, Anna Julia Cooper and Charlotte Forten Grimke of Washington, D. C.; Elizabeth Ensley of Denver; Alice Ruth Moore of New Orleans; and numerous others. ${ }^{54}$

The African American women's club movement, which originated by strongly backing Ida B. Wells' anti-lynching activities, went on to become a

${ }^{53}$ Gerda Lerner, "Early Community Work of Black Club Women," in Journal of Negro History, 59, no. 2 (April, 1974): 158-167.

${ }^{54}$ Ibid. 
significant force in strengthening and meeting many of the needs of the African American community. Individual and local club efforts initially coalesced into two organizations, the National Colored Women's League based in Washington, D. C., and the National Federation of Afro-American Women based in Boston. In 1896, the two united as the National Association of Colored Women, an organization that would eventually claim over 1,000 chapters and 50,000 members. ${ }^{55}$

T. Thomas Fortune, editor of the New York Age, gave Wells a job as journalist, making it easier for her to temporarily stay in New York. Fortune had used several of her articles in various issues of his paper and had become an admirer of her work, once writing:

She has become famous as one of the few of our women who handle a goose quill with diamond point as easily as any man in newspaper work. If Iola were a man she would be a humming independent in politics. She has plenty of nerve and is as sharp as a steel trap. ${ }^{56}$

When Wells went to New York in 1892, Fortune had been writing and speaking out against lynchings since the early 1880 s. In the mid-1880s, he

\footnotetext{
${ }^{55}$ For clarity on the African American women's club movement, see Charles Harris Wesley, The History of the National Association of Colored Women's Clubs: A Legacy of Service (Washington, D. C.: National Association of Colored Women's Clubs, Inc., 1984). See also Dorothy Salem, To Better Our World: Black Women in Organized Reform, 1890-1920 (Brooklyn: Carlson Publishing, 1990).

${ }^{56}$ Duster, Crusade For Justice, 32.
} 
began to conceive the idea of the Afro-American League, an anti-

discrimination organization with lynchings as a primary issue on its list of concerns.

Frederick Douglass revealed his admiration of Wells' anti-lynching work by writing a letter which emphasized the innovative character of her approach to speaking out against lynchings -- the elements that she brought to the protest which thrust it into the status of a movement. The letter commenced as follows:

Dear Miss Wells: Let me give thanks for your faithful paper on the lynch abomination now generally practiced against colored people in the South. There has been no word equal to it in convincing power. I have spoken, but my word is feeble in comparison. You give us what you know and testify from actual knowledge. You have dealt with the facts with cool, painstaking fidelity and left those naked and uncontradicted facts to speak for themselves. ${ }^{57}$

Douglass went on in the letter to emphasize the need for clergymen and churches to protest lynchings as Wells was doing and the impact that such protest would have. Douglass' letter was greatly appreciated by Wells, who obtained his permission to use it as an endorsement of her pamphlets

\footnotetext{
${ }^{57}$ Frederick Douglass to Ida B. Wells, 25 October 1892. Reprinted in the beginning of $\underline{\text { Southern Horrors and A Red Record. }}$
} 
$\underline{\text { Southern Horrors and its successor, } \underline{A} \text { Red Record. }}{ }^{58}$ Douglass reiterated his respect for Wells in a letter to the Rev. Charles Aked of Pembroke Chapel in Liverpool, England, and suggested that, if he were a few years younger, he would be even more involved in her crusade. ${ }^{59}$

That initial contact with Douglass would grow into a lasting and cherished friendship. Wells had already deemed him the grandest human specimen produced by the African American race. Her admiration of him was only heightened as she began to know him personally. They interacted at suffrage meetings and at African American women's club events, and she visited his home as a guest and collaborated with him on several projects before he died in 1895. When the English reformer Catherine Impey became interested in having a representative visit the United Kingdom to enlighten the society on lynchings in America, Douglass was approached as a possible spokesperson. However, due to the limitations of his age, he suggested Wells, an appropriate choice at this stage of the movement. The zeal that she possessed, fueled by her personal experience, made her the best candidate for strengthening the trans-Atlantic connection that had already

\footnotetext{
${ }^{58}$ Wells to Douglass, 17 October 1892, Ida B. Wells Papers, Special Collections, Reggenstein Library, University of Chicago.

${ }^{59}$ Douglass to Aked, 27 March 1894, Ida B. Wells Papers, Special Collections, Reggenstein Library, University of Chicago.
} 
been made. Her acceptance of the invitation initiated the process that is responsible for her name being associated with the initial phase of antilynching history. 


\section{CHAPTER SIX}

\section{Expanding Trans-Atlantic Connections: Ida B. Wells in the United Kingdom}

After 1892, Ida B. Wells began to express in her journalism the views and convictions that she had gained as a result of her investigations; that there was a connection between lynching and the maintenance of a subservient status for African Americans. For months after leaving Memphis, Wells had worked in the North to bring attention to "the truth" about lynchings, as well as to gain support for enforcing Constitutional law and its specificity regarding a trial by jury for American citizens accused of crimes. However, as T. Thomas Fortune had become disillusioned by a less than unified effort to abolish lynchings and other acts of discrimination, Wells also became discouraged for similar reasons. When she learned of the possibility of assistance from abroad, she viewed it as "an open door in a stone wall."1

The English reformer Catherine Impey, first became aware of Ida B. Wells at a National Press Association convention in Philadelphia in

\footnotetext{
${ }^{1}$ Alfreda Duster, ed., Crusade For Justice: The Autobiography of Ida B. Wells (Chicago: The University of Chicago Press, 1970) 86.
} 
September 1892. Impey was attending the convention as editor and representative of the English journal, Anti-Caste. When Wells was called to speak at the meeting, she brought the focus of the group to lynchings, and before the meeting was adjourned a resolution was adopted to establish a fund for protesting the crime. ${ }^{2}$

As plans began to be put in motion for Wells' trip to the United Kingdom, Anti-Caste set the stage for the impending anti-lynching lecture tour by the printing of a graphic photograph depicting a lynching scene in Alabama. The caption to the photograph read as follows:

Southern planters teaching their children how to treat offending (defenseless) negroes. Many hundreds of similar lawless scenes (and worse) are enacted every year in the southern states of America, and no one is punished. ${ }^{3}$

This photograph and the abundant references to lynchings in this particular issue and the following March/April 1893 issue reflected the rapid increase in lynchings during the decade of the 1890s. Among those mentioned was the "lynching at the curb" incident in Memphis, Tennessee, which occurred on March 9, 1892, and had motivated Wells' entrance into the anti-lynching

${ }^{2}$ Linda O. McMurry, To Keep the Waters Troubled: The Life of Ida B. Wells (New York: Oxford University Press, 1998), 170.

${ }^{3}$ Catherine Impey, "A Lynching Scene in Alabama," Anti-Caste 6, no.1 (January 1893): 1. 
movement. ${ }^{4}$

Anti-Caste's state-by-state survey of lynchings across America provided a vivid indictment of brutality in the nation. Subscribers of the journal must have been appalled by the prevalence and severity of the crime. Those two issues of Anti-Caste signaled the need for organized action and were the prelude to Wells' visit.

When Wells accepted the invitation to go to England, she had already received widespread publicity in America and had become a symbol of the cause. After her arrival in England on April 5, 1893, and a few days recuperation at Catherine Impey's home in Street, she began a hectic lecture series. That campaign commenced in Aberdeen, Scotland, with a "drawingroom meeting" at the home of Isabella Fyvie Mayo, Impey's partner in the venture and the primary person bearing the expense for the lecture tour. ${ }^{5}$ As Wells and Mayo continued the campaign in Huntly, Glasgow, and Edinburgh, Scotland, Impey went ahead to set up engagements in England, most of which were made through her connection with the Society of

\footnotetext{
${ }^{4}$ Catherine Impey, "Some Facts Respecting Lynch Law," Anti-Caste 6, nos. 3 \& 4 (March \& April 1893): 1.

${ }^{5}$ McMurry, To Keep the Waters Troubled, 187.
} 
Friends. 6

Wells' lectures, and the public response to them were immediately reported on by the press. The Peterhead Sentenel and the Buchan Journal summarized the first week of engagements by identifying Impey, Mayo, and Wells, describing the lynching mania in America and emphasizing the role that Anti-Caste had played in exposing lynchings. In reference to past accounts of lynchings in Anti-Caste, it was noted:

Some horrible stories are told in this pamphlet, which one cannot read without burning indignation. Were it not that the facts are spoken to by ladies, whose reputation for truth and carefulness is beyond suspicion, one would fain believe that such things could not be in these days of civilization and freedom. ${ }^{7}$

On May 17, 1893, Wells gave a lecture at the Young Men's Christian Association (YMCA) in Birmingham. The following day, May 18, the Birmingham Daily Gazette, carried a lengthy editorial describing the meeting and Wells' speech. The meeting was presided over by Counselor S. Lloyd, and Wells was introduced by R. L. Impey (possibly a relative of Catherine Impey). The format of her speech, as described in the editorial, can be viewed as being typical of her anti-

6 Duster, Crusade For Justice, 91.

${ }^{7}$ The Peterhead Sentinel and the Buchan Journal of 2 May 1893, reprinted in Crusade For Justice, 91. 
lynching speeches during the tour. In explaining the American scenario, Wells customarily began her lecture by informing the audience that the emancipation of African Americans had not brought them the level of freedom and equality that Britons had assumed it would. She noted that "resentment of the southern white people about the taking away of their slaves never ceased to show itself against the negro at every opportunity." ${ }^{8}$ From this point, the failure of Reconstruction as related to the systematic loss of the ballot and social and economic deprivations were outlined to indicate the then-current status of blacks. Finally, the use of lynch law as a tool to maintain that status was introduced to the audience, using statistics to show its prevalence. To this Wells' own personal experiences in Memphis were elucidated, which added validity to the accusations. ${ }^{9}$ These newspaper accounts were among the first of many to reach beyond the circulation boundaries of Anti-Caste and enlighten Scottish and English society on lynchings occurring in America.

The 1893 tour lasted three months, being cut short by difficulties between

8 "Lynch Law in the United States," The Birmingham Daily Gazette 18 May 1893: 8.

${ }^{9}$ Ibid. Other English newspapers reporting Wells-Barnett's speeches follow a similar dsecription, as do examples given in her autobiography. 
Impey and Mayo, severe enough to permanently damage their relationship, and bring an end to Wells' tour. ${ }^{10}$ However, the impact in England was sufficient to necessitate her return the following year to finish the work that she had begun. ${ }^{11}$

Wells was urged to return to the United Kingdom in February 1894 by Celestine Edwards, editor of Fraternity, and the Society For the Recognition of the Brotherhood of Man, the entity which had evolved to be the primary anti-lynching organization in Great Britain. At the time, she was in Chicago, Illinois, collaborating with Frederick Douglass, attorney Ferdinand Barnett, ${ }^{12}$ and author and editor, I. Garland Penn, on the composition of the pamphlet entitled The Reason Why the Colored American is Not in the World's Columbian Exposition. The pamphlet was obviously a response to the exclusion of African Americans from the exhibits of the Exposition. Billed as an international Fair "designed to associate all the races," it opened May 1, 1893, to thousands of international

10 See "Catherine Impey: Neo-abolitionist Extraordinarie" in this study as well as Duster, Crusade For Justice; McMurry, To Keep the Waters Troubled; Thompson, Ida B. Wells-Barnett: An Exploratory Study of An American Black Woman, 1893-1931, or most biographies on Wells-Barnett for details related to this incident.

11 Ware, Beyond the Pale, 190.

12 Ida B. Wells married attorney Ferdinand L. Barnett in 1895. He was also editor of the Conservator, Chicago's oldest African American newspaper. 
spectators. ${ }^{13}$ On assurrance that she would receive a stipend of two pounds per week in addition to her expenses, Wells agreed to return to England. ${ }^{14}$

When Wells arrived in England, Mayo insisted that she publicly disavow Impey. When she refused, Mayo retracted her promise to provide financial assistance. This placed Wells in an awkward and disadvantaged position, but she honored her commitment to the cause by staying and following through with the tour as planned. ${ }^{15}$ Donations from members of the SRBM, particularly those living in Bristol and referred to as "the Bristol Committee," and a few other individuals, made contributions to finance the tour. ${ }^{16}$

During this 1894 English tour, Wells was befriended by Rev. and Mrs. Charles F. Aked of Pembroke Chapel, who invited her to be a guest in their home. Aked was considered to be "the most influential and popular preacher in Liverpool." Wells had attended one of his church

13 "Ready For the Great Fair," New York Times 1 May 1893: 1.

14 Ida B. Wells to Frederick Douglass, 6 April 1894, Ida B. Wells Papers, Special Collections, Reggenstein Library, University of Chicago.

15 Mildred Thompson, Ida B. Wells: An Exploratory Study of An American Black Woman, 1893-1931 (Brooklyn: Carlson Publishing Inc., 1990), 52.

16 Ida B. Wells, Fraternity 1, no. 14 (August 1894): 2. 
services shortly after her arrival and was immediately impressed with the "young, eloquent" minister. She found his "inspiring" message, entitled "It is a Fearful Thing to Fall into the Hands of the Almighty God" to be "the most wonderful sermon that she had ever heard." Indeed, the enormous amount of respect that Wells had for Charles Aked moved her to name her first child after him. ${ }^{17}$ Only thirty years old at the time, Aked professed a brand of theology that not only rescued a "dying congregation," but held a special appeal for "reform-minded, dissenting Christians."18

Aked was aware of Wells' previous trip to England but had been unconvinced of her accusations of white America and had not permitted her to speak before his congregation at that time. However, he had since taken a trip to America to visit with Mrs. Henry Ward Beecher, wife of the former abolitionist. During his stay, he went to the World's Columbian Exposition in Chicago where he became acutely aware of a well publicized lynching that had recently occurred in Kentucky. That lynching, of a man who turned out to be innocent, plus a letter of recommendation from Frederick Douglass

${ }^{17}$ Duster, Crusade For Justice, 126.

18 Patricia A. Schechter, Ida B. Wells-Barnett and American Reform, 1880-1930 (Chapel Hill: University of North Carolina, 2001), 98. 
made Aked more receptive to Wells when she returned to England in 1894. ${ }^{19}$ This time, she was permitted to speak before his congregation where there was "a large and enthusiatic audience of 1,200 persons, at Pembroke Chapel, the third night after landing."20 Aked also frequently featured Wells' writing in the chapel's organ, The Liverpool Pulpit. ${ }^{21}$

Being well versed in American history, Aked began making protestations about this new aspect of it. The topic fit well into his sermons and essays carried in newspapers and journals. For example, in "The Race Problem in America," an article which appeared in The Contemporary Review, he provided a chronology of American history and its African American citizens, emphasizing the oppressive status of African Americans during the various historical periods. To stress the brutal and dehumanized character of chattel slavery, Aked continually used examples which juxtaposed the ideals of democracy and the "peculiar institution." Of the repercussions of abolitionist activity in America, he recalled incidents when:

[William] Lloyd Garrison had been dragged through the streets of Boston with a rope around his neck. Georgia had set a price of five thousand dollars on his head. Love-

19 Duster, Crusade For Justice, 126.

20 Ibid., 129.

21 Schecter, Ida B. Wells-Barnett, 98. 
joy had fallen riddled with bullets fired by ruffians from the slave state of Missouri ... Prudence Crandall had been imprisoned in the free state of Connecticut for teaching Negro children to read and write. ${ }^{22}$

An extensive discourse was given in the article on the lengths to which southern whites went to nullify the citizenship privileges that blacks had gained during the Reconstruction era. It was not enough, he concluded, that African Americans were disfranchised, subjected to convict lease systems, and socially segregated, but "to this indictment of Southern justice has to be added the frightful charge of violence and lynch law."23

Aked continued by supplying numerous tabulated statistics and descriptions of lynchings which had occurred across America. He was meticulous in punctuating the lurid details of torture that many victims endured. ${ }^{24}$ Much of this information was very likely readily accessible through the convenience of having Wells as a guest in his home and the availability of her pamphlet, $\underline{A}$ Red Record, which was then being circulated thoughout England. ${ }^{25}$

\footnotetext{
22 Charles F. Aked, "The Race Problem in America," The Contemporary Review LXV (January - June 1894): 820.

23 Ibid., 823

24 Ibid.

25 Ibid.
} 
Taking a leadership position at the annual National Baptist Union meeting, which took place in England in May of 1894, Aked made a motion to adopt a resolution denouncing lynchings in America. This move was intended to be a deliberate showing of support for the anti-lynching cause. Ministers at the meeting had recently become aware of the position of silence taken by many southern American clergymen in regard to lynchings. Of particular concern were articles written by southern ministers who appeared to have been condoning lynchings on the grounds of defending the honor of white women. ${ }^{26}$

Dr. John Clifford, minister of Westbourne Park Chapel, seconded the motion. As a noted scholar and head of Politechnique Institute in London, his endorsement of the motion and the anti-lynching movement made a positive statement. The resolution was wholeheartedly adopted by members of the National Baptist Union, who were clearly moved by Aked's speech and his absolute conviction to the anti-lynching movement. Aked concluded his presentation with an appeal to American churches to begin speaking out against the crimes. ${ }^{27}$

${ }^{26}$ Duster, Crusade For Justice, 164.

${ }^{27}$ Ibid., 166. 
Future visits to the United States provided opportunities for Aked to make statements regarding lynchings and other aspects of discrimination. One such occasion was as guest speaker at the University of Chicago in 1895. Wells-Barnett (she was married by this time) was present and recalled that his speech "touched most eloquently upon things for which we should be thankful, as well as those we should labor against, and of course lynching came under that head." He made an overt movement for liberalism that particular day by inviting Wells-Barnett to accompany him to the school's football game, where he was to view the game with the president of the University and his party. Although Wells-Barnett knew nothing of football, she was eager "to aid in giving a lesson in real democracy" to Americans. ${ }^{28}$

While Wells was in Liverpool, she received enough response from local Unitarian and Congregational ministers to speak before "ten large meetings" and felt that the most important was the one over which Sir Edward Russell, editor of the Liverpool Daily Post, had presided. ${ }^{29}$ Newspapers such as The Mercury "gave splendid notices of [their]

28 Ibid., 247.

${ }^{29}$ Ida B. Wells, "Miss Wells' Second English Trip," Fraternity 1, no. 14 (August 1894): 4. 
meetings, also strong leaders," and the Liverpool Review printed a series of articles and a portrait. ${ }^{30}$

In Manchester, Wells addressed twelve meetings, which were arranged by her hosts, Mr. W. E. A. Axon, and a "Mrs. Carter," the local secretary of the SRBM. A week of "most influential meetings" followed in Bristol, which were made possible "through great exertions by two young lady secretaries, Mrs. Fox and Sowter," Mrs. Sowter being the wife of the Reverend G. A. Sowter,Vicar of St. Silas Parish. A large meeting was held in the Y. M. C. A. hall, where Reverend Sowter presided, and representative ministers of every denomination were on the platform..$^{31}$

In Newcastle, Wells was the guest of "Mrs. Robson," whom she credited with having taken "excellent care" of her, and she was "afforded excellent opportunites for reaching the public" by Miss Thompson, Mrs. Hartley, and Reverend Walter Walsh. ${ }^{32}$ Aided by funds provided by the Bristol Committee, Wells went on to London where she spent seven weeks delivering lectures and giving interviews to the press. She noted: Many anti-lynching resolutions were passed by Baptist and

${ }^{30}$ Ibid.

${ }^{31}$ Ibid.

${ }^{32}$ Ibid. 
Congregational Unions, Unitarians, [the] Aborigines Protection Society, the British Women's Temperence [Union], and the women members of the Society of Friends. ${ }^{33}$

The formation of the London Anti-lynching Committee was "a most memorable event" for Wells. She noted in her autobiography that on the last night of her stay in London, "they gathered together a most brilliant company in honor of my presence and my leaving. At the conclusion of the social pleasure, they formed an Anti-lynching Committee."34 The extensive list of committee members included numerous distinguished English citizens. Heading the list was the Duke of Argyle, son-in-law of Queen Victoria. ${ }^{35}$ The Revs. Charles Aked and John Clifford and several other ministers; numerous members of Parliament; and the editors of the Manchester Guardian, The Bradford Observer, the Contemporary Review, the London Daily News, the Daily Chronicle, and the Daily Post were among the notable personages who joined the Anti-lynching Committee. Later, a number of Americans such as labor leader, Samuel Gompers; Francis Willard; Richard Watson Gilder, editor of Century Magazine; and several bishops and numerous ministers also became members. Although

33 Ibid.

34 Duster, Crusade For Justice, 215.

35 Thompson, Ida B. Wells-Barnett, 54. 
other anti-lynching committees were formed in the United Kingdom, this one was the largest. ${ }^{36}$

In her book, Golden Cables of Sympathy, Margaret McFadden identifies international connections between nineteenth century American and European female libertarians which began to develop during the abolitionist movement. McFadden terms the communicative networks that were established between these international feminists, evangelists, and humanitarians as "golden cables of sympathy." She dubbed Ida B. Wells a "symbolic granddaughter" of Lucretia Mott's generation -- Mott having given anti-slavery lectures on the same lecture curcuit in 1840 that Wells' traveled while in England and Scotland during the 1890s. ${ }^{37}$ McFadden also contends:

women on both sides of the Atlantic were using these slowly built up friendships, groups, meetings, and contacts-- this web of networks -- for their campaigns against lynching, alcohol, and white slavery and for woman suffrage, international peace, and women's economic rights. ${ }^{38}$

As intended, Wells' return to England had the effect of fueling the

${ }^{36}$ Duster, Crusade For Justice, 216.

${ }^{37}$ Margaret McFadden, Golden Cables of Sympathy (Lexington: University Press of Kentucky, 1999), 184-186.

${ }^{38}$ Ibid. 
movement. According to historian Emma Lou Thornbrough, "one British clergyman said that nothing since Uncle Tom's Cabin had taken such a hold on public opinion as the anti-lynching crusade."39 Celestine Edwards, the editor of Fraternity professed that Wells':

second visit to this country has been marked by an awakening of profounder sympathy and interest with the Afro-American. Public indignation has been aroused, and strong resolutions have been carried at almost every meeting Miss Wells addressed. At Liverpool all the newspapers reported her harrowing stories of lynching and other acts of injustice inflicted upon the Negroes in the South. ${ }^{40}$

Also, in Liverpool, a "powerful letter" had been sent to the Christian

Recorder, the organ of the English Unitarian Church, by the Rev. R. A.

Armstrong. The letter was considered by Celestine Edwards to have been

"a fine appeal to the hearts of those who venerate the words and works of

Channing and Parker, the brave John Brown, and the immortal Lloyd

Garrison."41

Wells' journalistic skills were immediately put to use by Fraternity while she was in the United Kingdom. Shortly after her arrival, the journal

${ }^{39}$ Emma Lou Thornbrough, T. Thomas Fortune (Chicago: University of Chicago Press, 1972), 125.

40 S. J. Celestine Edwards, "What We Think," Fraternity 1, no.10 (April 1894): 1.

${ }^{41}$ Ibid. 
carried the article titled "The State's Lynching Record For 1893: From An American Standpoint." In it, lynching statistics from the Chicago Tribune were listed. The statistical record showed that in 1893, two hundred persons were lynched in the United States. Of that number, 30 were white, 5 were Mexican, 7 were Indian, and an overwhelming 158 were African American. Wells noted that because of "such frivolous pretexts" as the alleged crimes for lynchings, the "158 swells the list of Judge Lynch's victims for the past twelve years to near two thousand Negro men and women, that are known to have been hanged, shot, and burned to death."42

On June 9, 1894, Wells left London and returned to Bristol to make a final report to the Bristol Committee which had incurred the expense of the London trip and had also sent "over a thousand copies of English papers to America." The 1894 trip was concluded with speeches in Southport, Bradford, Wigan, Leeds, two more in Bristol, and another at Pemboke Chapel in Liverpool before returning to America on July 12, 1894.43

42 Ida B. Wells, "The State's Lynching Record For 1893: From An American Standpoint," Fraternity 1, no. 9 (March 1894): 6.

43 Ida B. Wells, Fraternity 1, no. 14. August, 1894. 2. 
From March to July of 1894 , Wells campaigned vigorously for anti-lynching support in the United Kingdom. ${ }^{44}$ The two trips abroad had significantly aided the work that Catherine Impey and Anti-Caste had started in the 1880s. As a result, lynching atrocities in America had been revealed to an appalled and sympathetic society beyond American shores. The impact in America was definite, bringing embarrassment to government officials, and an inclination by some to begin perceiving the crime from a different perspective, which facilitated a new outspokeness by many who had heretofore been silent.

When Wells returned permanently to America (ca. July 24, 1894), ${ }^{45}$ she was sufficiently inspired to continue the crusade. Greeted in New York by "a large audience at Bethel African Methodist Episcopal Church," she gave an account of her sojourn and made an appeal for similar support. ${ }^{46}$ Arriving in Chicago a few days later, Wells received a warm welcome from the African American community, who "tendered a public reception" at Quinn Chapel. ${ }^{47}$ For the next year, she traveled throughout the country, with

\footnotetext{
44 The Daily Inter-Ocean printed Wells' accounts of the 1894 lecture tour. See the Ida B. Wells Papers, Special Collections, Reggenstein Library, University of Chicago; Also see Duster, "Inter-Ocean Letters," Crusade For Justice, 125.

45 Duster Crusade For Justice, 218.

46 "Miss Wells's Plea For The Negro," New York Times 30 July 1894: 16.
} 
the exception of the southern states, speaking before churches and other groups, who in turn made resolutions against lynchings and formed antilynching committees. During this period of crusading in America, Wells received the attention of the press as she had in England and Scotland, and although the editorials related to her lectures were overwhelmingly favorable, there were some that questioned her motives in the crusade or accused her of over-stepping her bounds as a female. The New York Times labeled her "a slanderous and nasty-minded mulattress, who does not scruple to represent the victims of black brutes in the South as willing victims."48 Southern newspapers maintained a hostile position against her allegations as they had since her exile from the south and throughout her travels abroad. ${ }^{49}$

In late August of 1894, the Anti-Lynching Committee of London responded to a challenge by southern newspapers to come to the United States and see for themselves the inaccuracy of Wells' accusations. A representative group, headed by the Duke of Argyl and Sir John Gorst launched a personal query of southern lynchings by meeting with several

47 The Chicago Inter-Ocean 8 August 1894: 2; Also see Duster, Crusade For Justice, 225. 48 "British Anti-lynchers," New York Times 2 August 1894: 5.

49 Sadie Daniel and Hallie Q. Brown, Women Builders (Washington, D. C.: Associated Publishers, 1970), 278. 
southern governors. The committee received less than a warm welcome from southern governmental officials who suggested that they use the same initiative in their own country with Ireland, Jack the Ripper, and other British concerns. During the committee's investigation, a "sextuple lynching" occurred in Milligan, Tennessee, the circumstances of which supplied the appropriate evidence and necessary verification for the English inquiry. .50

How the British component of the anti-lynching campaign felt about their role in the favorable response that Wells received on her return to America was summed up by Catherine Impey:

There is great cause and thankfulness and encouragement in the evidences which reach us of awakening consciousness and invigorated action on the part of our sister nation. The consciousness of white America has, we believe, now been too deeply stirred for this matter to be allowed to rest. Moreover, Miss Wells, the National Citizen's Rights Association, and others on the spot are ceaselessly agitating for justice to the outraged race. The old objective that British protests won't avail with independent Yankees, \&c., meets us less frequently since it has been recognized that Miss Ida B. Wells's voice has been better heard in America from the platform of Exeter Hall, than from any American platform that was previously open to her. It has been recognized now, that where a whole nation is under the spell of such sentiment, the awakening must come from outside. ${ }^{51}$

${ }^{50}$ McMurry, To Keep the Waters Troubled, 227.

${ }^{51}$ Catherine Impey, "Editor's Annual Address," Anti-Caste 7 (March 1895): 2. 
The nineteenth century anti-lynching efforts of Ida B. Wells-Barnett culminated in activities associated with her position as head of the Antilynching Committee of the Afro-American Council. The Afro-American Council was organized as a continuance of T. Thomas Fortune's AfroAmerican League in 1898. Interest in reconvening the Afro-American League initially came from Bishop Alexander Walters of the African Methodist Episcopal Zion Church. Walters, feeling outrage at the continued and severe victimization of African Americans, and in particular, the lynching of two recently employed United States postmasters, sent a letter to T. Thomas Fortune, encouraging him to call a meeting of the defunct AfroAmerican League to see what could be done. ${ }^{52}$

Specifically focusing on the lynchings of postmaster Frazier Baker of Lake City, South Carolina, and another postmaster in Hogansville, Georgia, Walters' letter expressed little confidence in justice prevailing in either case. In addition, Walters registered his concern about what he believed to be "a determined effort on the part of white labor unions of the country to exclude the Negro from the industrial avenues in which he [could] make an honest

52 Emma Lou Thornbrough, "The National Afro-American League, 1887-1908," in The Journal of Southern History, 27, no. 4 (November 1961): 501. 
living." In view of these realities, it was, in Walters' assessment, "necessary to organize for self protection." 53

The apparent frustration over the retrogressive status of the race in general and the need to make a statement about the two lynchings was indicated by the overwhelming response to Walters' appeal. Included among the long list of respondents were attorneys, educators, ministers, and newspaper editors, some of which had been members of the Afro-American League. ${ }^{54}$

Wells-Barnett was one of the respondents to Fortune's letter. After the lynchings of Frazier Baker in Anderson, South Carolina, she and other citizens of Chicago held a mass meeting which resulted in the passing of resolutions denouncing lynchings and a decision to send a delegation to Washington, D. C. to plead for justice in the Baker case. The delegation was made up of Wells-Barnett and other leading citizens and politicians from Chicago and Washington. ${ }^{55}$

It was believed that these particular lynchings, in which the victims were Federal employees, represented a situation in which the Federal Government was bound to intervene. Aparently the group was well received by President

${ }^{53}$ Alexander Walters, My Life and Work (New York: Fleming H. Revel, 1917), 98.

${ }^{54}$ Ibid., 101.

${ }^{55}$ Duster, Crusade For Justice, 252. 
William McKinley, who accepted the resolutions and assured them that he had already dispatched "some of their finest secret service agents" to the matter. Unfortunately, at the time, governmental attention was being diverted by the country's focus and involvement in the Spanish American War and Federal intervention was not forthcoming. ${ }^{56}$

T. Thomas Fortune was less than enthusiastic about the prospect of pulling the Afro-American League together again. Having been vastly disappointed with the outcome of the initial effort and the lack of unity in the African American community, his reluctance was clearly evident when Walters approached him with the idea. However, he told Walters that he would issue a call to reorganize if he [Walters] could secure a petition of at least one hundred signatures in support of the venture. Walters secured the signatures, and on August 24, 1898, Fortune published an open letter in the New York Age responding to Walters and the supporters of the potential reorganization. The letter is reprinted here in its entirety to emphasize public receptiveness to Walter's request and Fortune's hesitancy toward reassembling the League.

To Bishop Alexander Walters, Jersey City, N. J.:

56 Ibid., 253. 


\section{My dear Sir:}

On the 10th of March last you did me the honor to suggest that I issue, as president, a call for the resurrection and rehabilitation of the Afro-American League, which was organized at Chicago, Ill., January 15, 1890, the second and last meeting of which was held at Knoxville, Tenn, in 1892. Since the first publication of your request in the Age, March 10th, last, numerous persons, to the number of one hundred fifty, have joined on the request, and their names have been published from time to time, attached to your request, and have therefore become a part of it, attaching national importance to the desire for some organized expression of Afro-American opinion of the conditions which confront the race and which differ but little from those stated by me in 1890, as a sufficient provocation for calling the Afro- American League at Chicago.

I have given your request long and faithful consideration, and have reached the conclusion that the popular sentiment behind the request does not justify me in acceding to it. There is just as much need of the Afro-American League today as there was in 1890; there is even more need for such an organization; but I do not believe that the masses of the race are any more ready and willing to organize local and State Leagues of the National League and to sustain them by moral and financial support than they were in 1890 and 1892. I am therefore not willing to take the responsibility of undertaking the resurrection of the Afro-American League when the chances of effecting a permanent organization are so very doubtful.

But, in deference to the desires of yourself and the persons who have joined you in the request, and after consultation with responsible men and women in all parts of the country, who feel with me that something of an organized nature should be done to stem the tide of wrong and injustice of which the race is made victims, I have decided to call a conference at Rochester, New York, September 15, 1898, to consider existing conditions and to take such action as may be wise, loyal and patriotic for the future, the conference to be composed of those who have joined in the request for the resurrection of the AfroAmerican League, and others as may appear at Rochester and desire to participate in the work of the conference.

My excuse for calling the conference at Rochester is to take advantage of the race sentiment which will be invoked by the unveiling of a monument to Frederick Douglass, in Rochester, 
September 14, a city in which Mr. Douglass spent some of the years of his life, and one of the freest and most tolerant cities in the Republic, whose hotels and homes and press will receive the conference with open arms and generous hospitality.

Persons desiring to attend the conference should write to Mr. John W. Thompson, P. O. Box 493, Rochester, New York, for railroad rates and hotel accommodations.

Invoking the Divine blessing on the proposed conference, and thanking you, Bishop Walters, and your co-signers for the honor you have done me in your request, I am, with sentiments of high regard, Yours truly,

T. Thomas Fortune.

New York Age, August 24, 1898.57

On September 15, 1898, one hundred and fifty delegates attended Fortune's conference in Rochester, New York, to consider the feasibility of reviving the Afro-American League. Wells-Barnett was in attendance, as was Mrs. Helen Douglass, widow of the late Frederick Douglass; Susan B. Anthony; the former minister of Liberia, John H. Smith; Chris J. Perry, editor of the Philadelphia Tribune; and others. ${ }^{58}$ The conferees determined that there did exist a definite need for such an organization, but rather than reorganize the old League, the decision was made to start anew under the name Afro-American Council. The objectives of the Afro-American Council were similar to those of the Afro-American League; however, this time,

57 Walters, My Life and 'Work, 102.

58 Ibid., 105. 
combating lynchings was number one on its list of concerns. ${ }^{59}$

As the mission of the organization began to emerge at the initial meeting of the Afro-American Council, Fortune's guiding influence was less prominent as the entity became spearheaded by more optimistic members. When the motion was made to make Fortune permanent chairman, the motion was halted by Wells-Barnett, who did not believe that Fortune could effectively lead the organization after declaring his lack of faith in it. ${ }^{60}$ It was finally agreed that Bishop Alexander Walters would take the presidency, J. C. Dancey would become vice president, Wells-Barnett would serve as secretary, and John W. Thompson as treasurer. An Executive Committee was also selected. ${ }^{61}$ Historian Emma Lou Thornbrough notes that Walters and Fortune "held the presidency and the chairmanship of the executive committee during almost the entire history of the Council," and in 1902, after the Council came under the influence of Booker T. Washington, Fortune was elected president. ${ }^{62}$

${ }^{59}$ Ibid.

${ }^{60}$ Duster, Crusade For Justice, 255.

61 Walters, My Life and Work, 106.

62 Thornbrough, " National Afro-American League," 501-504. 
The next meeting of the Council was held in Chicago in 1899, at which time Wells-Barnett was made head of the Anti-lynching Committee after resigning as secretary. She was one of the planners for the meeting and banquet which was held at Chicago's Sherman Hotel. As presiding officer of the event, she was charged with introducing president Walters and "other representative men" such as, W. E. B. DuBois and Bishop Henry McNeal Turner. ${ }^{63}$

Using the then current state of affairs regarding the crime of lynching, Wells-Barnett and the other members of the Anti-lynching Committee composed the following declaration:

The lynching evil is still with us, the most grievous ill to which our race is subjected. Added to the 10,000 victims of mob law, who have been hanged, shot and burned to death without judge or jury within the last twenty years, the year 1897 gave 167 victims. The present year averages about the same number. For the first time in lynching history this year has furnished a case which will permit action by the United States Government. Reference is made to the case of Postmaster Baker, who was shot and burned to death in Lake City, S. C., because he accepted the office of postmaster in his town. Men have been apprehended and charged with being participants in that dreadful crime, but they are out on bail. We recommend that the Executive Committee be empowered to carry on the agitation against lynch law throughout the length and breadth of the land and Postmaster Baker's case in particular. ${ }^{64}$

63 Duster, Crusade For Justice, 261.

64 Walters, My Life and Work, 106. 
As chairman of the anti-lynching committee, Wells-Barnett set up an office in Chicago and sent out letters asking the community for financial assistance to investigate lynchings, and for help in "disseminating" accurate reports on lynchings. She viewed the position as one in which she could expand her anti-lynching work and assured the recipients of the letter that the work of the committee would be the same as she had "individually conducted for seven years: agitating, investigating and publishing facts and figures in the lynching evil." Seven years prior to this 1899 declaration would have been 1892 which further validates the point in time that Wells-Barnett entered the anti-lynching movement. ${ }^{65}$

The Afro-American Council served as a temporary vehicle for addressing lynchings, but after the turn of the century, according to historian Thomas C. Holt, it also "became defunct, a victim of the struggle between [Booker T. ] Washington and his opponents." Wells-Barnett had by that time, realized the limitations of "agitation" in regard to lynchings and began to push even more for Federal intervention. ${ }^{66}$

${ }^{65}$ The Colored American (7 October 1899): 1.

66 Thomas C. Holt, "The Lonely Warrior: Ida B. Wells-Barnett and the Struggle For Black Leadership," in John Hope Franklin's and August Meier's Black Leaders of the Twentieth Century (Urbana: University of Illinois Press, 1982), 51. 
Political enfranchisement was high on the list of attainments of those who spoke out against lynchings. In Stewart Tolney's and E. M. Beck's book, A Festival of Violence: An Analysis of Southern Lynchings, 1882-1930, it is noted that one of the factors which motivated "large-scale opposition to lynchings among whites," was the enforcement of anti-racist legislation. ${ }^{67}$ It was to this end that most protestors of lynchings also advocated political involvement. For example, enfranchisement and unified political action by blacks was an important element in T. Thomas Fortune's Afro-American League and Albion Tourgee's Citizen's Equal Rights Association. Wells-Barnett was no exception. Realizing that African Americans could not protest unfair legislation or promote supportive politicians without the ability to vote, she consistently advocated for unadulterated enfranchisement as a means of abolishing lynchings. As a confrontationist, she viewed the attainment of suffrage rights for males and females, and the exercise of those rights for political empowerment as being necessary for liberation. Having been exposed to politically active adults while growing up in Mississippi, she recognized early the need for political unity in the African American community. She also observed that

\footnotetext{
67 Stewart E. Tolney and E. M. Beck, A Festival of Violence: An Analysis of Southern Lynchings, 1882-1930 (Urbana: University of Illinois Press, 1995), 35.
} 
blacks in the South who tended to follow Booker T. Washington's philosophy of quietly acquiring land and seeking self sufficiency through agrarian channels had not realized their expected goal of non-molestation by whites. In reference to that, she noted that "the more lands and houses he acquired, the more rapidly discrimination laws have been passed against him by those who control the ballots, and less protection is given by the lawmakers for his life, liberty and property." 68

During the 1890 s, there were efforts by certain white politicians to enact anti-lynching legislation. Between 1893 and 1897, at least six states passed anti-lynching laws: North Carolina, South Carolina, Georgia, Ohio, Texas and Kentucky. Govs. James Hogg of Texas, William Atkinson of Georgia, William Bradley of Kentucky, and a few others urged the passing of anti-lynching legislation. On the Congressional level, Congressman Henry Blair of New Hampshire unsuccessfully pushed for the passing of a resolution against lynchings in August $1894 .{ }^{69}$

Wells-Barnett's political convictions were reinforced as she witnessed the effect of anti-lynching legislation when the Illinois State Legislature passed

68 Ida B. Wells, "How Enfranchisement Stops Lynching," Original Rights Magazine (June 1910): 44. Also included in Thompson, Ida B. Wells-Barnett, 267.

${ }^{69}$ Daniels and Brown, Women Builders, 279. 
its Anti-lynching Bill in 1905. The bill sought the suppression of mob violence and the punishment of those who incited lynchings by providing for damages against the city and county which permitted lynchings. It also sought to punish sheriffs who failed to protect their prisoners from lynch mobs. The case that set a precedent and caused future sheriffs to think about the consequences was that of Sheriff Frank E. Davis of Cairo, Illinois, who was charged with failing to prevent the lynching of two of his prisoners. Evidence indicated that Davis could have done more to protect the prisoners in his care -- his failure to do so resulted in the loss of his job. ${ }^{70}$

Wells-Barnett had a powerful impact on the anti-lynching movement of the nineteenth century. Her ability to inspire action is evident in three specific reactions to her protest journalism, anti-lynching literature, and speeches. The confrontational approach which she employed, made her a catalytic element in stagnant or newly developing movements in the 1890 s and later during the twentieth century. She provided the spark -- in the form of information, methodolgy, and advocacy of right action which motivated the involvement of others.

The first mass reaction to Wells' protest journalism occurred immediately

70 Wells, How Enfranchisement Stops Lynching, 271. 
after the Memphis lynchings, when hundreds left the city and moved to the midwest. Other factors had inspired blacks to emigrate from Tennessee to midwestern states prior to that time, particularly during the late 1870s, when so many African Americans from that region took Benjamin "Pap" Singleton's advice to settle in Kansas. It is significant that in 1892, as Wells repeatedly encouraged blacks to leave Memphis, hundreds heeded the advice. In addition, those African American residents who chose to remain in Memphis vented their frustration over the lynchings by boycotting the city's transportation system, an action that was sanctioned and encouraged by Wells. Both of these forms of retaliation, which had a dire effect on white businesses, provided alternative outlets and instilled a sense of satisfaction and empowerment in the African American populace of Memphis.

Another mass reaction to Wells' protest journalism related to the overwhelming response of African American women in the Northeast, who were moved to solidify their community work efforts into organized clubs. Although African American females had already begun to address limitations in their communities, it was Wells' editorials in the New York Age and her testimonial speech at New York's Lyric Hall that motivated 
numerous women to become more of an organized force in solving problems such as lynching, disfranchisement, education, and poverty. Although the agenda of African American women's clubs was based on the needs of the community, historian Gerda Lerner notes that the initial "stimulus" for organizing the clubs "was political: the defense of the race against lynchings."71

The anti-lynching campaign in the United Kingdom and the impact that it had in America represents the third mass reaction to Wells' magnetism and ability to inspire action during the nineteenth century. The editorials initially appearing in Anti-Caste, which were written by Impey, Douglass, Fortune, Tourgee, and others, had paved the way for Wells' visit to the region. However, the publication of Southern Horrors and A Red Record and her lecture tour in the United Kingdom garnered enough sentiment among Scots and Britons to vehemently denounce lynchings. While there were other attempts to organize in protest of lynchings with the establishment of the Afro-American League and the Citizen's Equal Rights Association, the reactions to lynchings that Wells generated in the $1890 \mathrm{~s}$, serves as an attestation to the catalytic influence that she brought to the

71 Gerda Lerner, "Early Community Work of Black Women," in Journal of Negro History, 59, no. 2 (April 1974): 160. 
developing movement.

Ida B. Wells-Barnett made an indelible mark on the nineteenth century anti-lynching movement; the drive and conviction that she brought to it gave it the push that was needed to awaken public sentiment and consciousness enough to move the campaign forward. It is very likely that without her input, the forces which came together for the eventual decline in the occurrence of lynchings would have been significantly delayed. Although she remained an agitator and social activist throughout her sixty-nine year life, continuing to investigate lynchings and addressing other forms of discrimination, she was most intensely involved in the anti-lynching movement between 1892 and 1900. Prior to 1892, the evolving racial turbulence of the 1880 s had been protested by that initial group of agitators: Frederick Douglass, T. Thomas Fortune, Albion Tourgee, and others brave enough to speak out against the crime. Just as their efforts had been helped by Catherine Impey and her exposure of the crime in Anti-Caste, the catalytic phase, as represented by Wells was also greatly facilitated by Catherine Impey and the activities of other personages overseas. 


\section{CHAPTER SEVEN}

\section{Fraternity}

Anti-lynching protest in the United Kingdom was literarily defined by two journals; Anti-Caste during the first phase of the anti-lynching movement, and Fraternity during the final phase. The trans-Atlantic link of the movement was sustained by these journals. Fraternity replaced AntiCaste when Catherine Impey's input became less prominent, and the new journal was created with the desire of maintaining the interest in the antilynching campaign that had been generated by Ida B. Wells' presence in England and Scotland. Fraternity was representative of an organizational shift in the British expression of the movement which occurred in 1893. When the catalytic phase of the anti-lynching campaign convened with the arrival of Ida B. Wells in the United Kingdom, a new organization, the Society for the Recognition of the Universal Brotherhood of Man (SRUBM) was established. However, it was after Wells' departure and Impey's diminution that the organization evolved into a significant factor in the antilynching campaign. The SRUBM was: 
Fundamentally opposed to the system of race separation by which the despised members of a community are cut off from the social, civil and religious life of their fellow man. It regards lynchings and other forms of brutal justice on the weaker communities of the world as having their root in race prejudice, which is directly fostered by the estrangement, and lack of sympathy consequent on race separation. ${ }^{1}$

Isabella Fyvie Mayo played a crucial role in bringing Ida B. Wells to the United Kingdom, the establishment of the SRUBM, and in maintaining the organization in the final phase of the anti-lynching movement. Mayo's philanthropic tendencies had led her to take in lodgers from different parts of the world. When she learned of lynchings in America through Catherine Impey and Anti-Caste, she felt compelled to work with Impey in bringing an American representative to the United Kingdom to speak about the atrocities. ${ }^{2}$

Mayo was born in Buchan, a remote district of Aberdeenshire, Scotland, ca. 1843. She was from a typical Scottish middle class family that relied on servants to run the home, so much so that they "only had cold food on Sundays," the servant's day off. As a child, she remembered learning to read at four years of age and spending Sunday evenings with her family reading

1 Vron Ware, Beyond the Pale; White Women, Racism and History (London: Verso, 1992), 175.

2 Alfreda Duster, ed., Crusade For Justice (Chicago: University of Chicago Press, 1970), 85 . 
the Bible and reciting Catechisms. Mayo was the author of several books written under the pseudonym Edward Garrett. However, the topics of her books were non-political, relating more to her personal life, rather than the social reform work in which she was involved. She even failed to mention those activites in her autobiography entitled Recollections of Fifty Years: What I Saw, What I Lived Through, and What I Learned, During More Than Fifty Years of Social and Literary Experience, which she published in $1910 .^{3}$ At the request of Mayo, the Caribbean native, writer and editor, Celestine Edwards, assumed the leadership role in the SRUBM during the summer of 1893, after a serious personal dispute had created a rift between Mayo and Catherine Impey, the founders of the organization. The separation brought a temporary cessation of the publication of Impey's journal AntiCaste, when a new journal, Fraternity was launched as the official organ of the SRUBM, with Edwards as its editor.

Impey and Anti-Caste had already set the stage for sympathetic reactions to the American crime of lynching. When she and Mayo brought Ida B. Wells to the United Kingdom, those early efforts quickly

${ }^{3}$ Isabella Fyvie Mayo, Recollections of Fifty Years: What I Saw, What I Lived Through, and What I Learned, During More Than Fifty Years of Social and Literary Experience (London: John Murry, 1910), 13. 
crystalized into a definite crusade that was fed by Wells' presence and involvement. When Wells left Europe in 1893, Edwards stepped in to continue the work.

Edwards' editorship of Fraternity and greater involvement by the SRUBM helped form the basis for a better organized anti-lynching movement. The movement had gone from an informative, expose stage in Anti-Caste to an action phase by people who had been inspired first by the Anti-Caste articles and then by Wells' personal descriptions of the American atrocities.

Wells' first hand experience in the American South, her having been a witness to the effects of lynchings, her having a personal connection to "the lynching at the curve" incident in Memphis, and her involvement as an investigator into the "true causes" of lynchings catapulted her to the forefront of the crusade. The impact that she had on the anti-lynching movement was akin to the effect that the first-hand experiences of Frederick Douglass, William Wells Brown, William and Ellen Craft, Henry Highland Garnet, and other fugitive slaves had on the anti-slavery movement, although that movement had begun with the efforts of free black and white humanitarians in America and England. In the same 
manner, prior to Wells' involvement, the anti-lynching campaign had begun with the early efforts of concerned American and English activists.

In his important work on the impact of fugitive slaves in the abolitionist movement, R. J. M. Blackett described the infusion and impact of blacks who had experienced slavery on the British abolitionist lecture circuit as being significant, noting:

Over the decades blacks developed a well-oiled and pretty efficient propaganda machine, which they employed to 'modify opinion' by exposing the shortcomings of American society and to re-educate potential allies to approve and accept the condemnations leveled against slavery and discrimination. The machine involved extensive lecture tours covering most of the British Isles and personal contacts with people from all walks of life. Slave narratives were published and sold, and fugitives recounted their moving and dramatic escapes at public meetings. Blacks showed panoramas that depicted the barbarity of slavery and used special events like the Great Exhibition of 1851 to dramatize the plight of the slaves. Whenever possible they also used other philanthropic movements such as temperance, to bring information about slavery to a wider audience. ${ }^{4}$

The new head of the movement, Celestine Edwards, the youngest of nine children, was born in Dominica but had settled in England in the 1870s when he was a teenager. At that early age, he was a devout Christian and "champion of the Temperance Movement, for which he campaigned in

${ }^{4}$ R. J. M. Blackett, Building An Antislavery Wall (Ithaca: Cornell University Press, 1983), 13. 
Scotland and England." A charismatic speaker, Edwards drew exceptionally large crowds to his public meetings. ${ }^{5}$ When Isabella Mayo began to seek an editor for the new journal, she immediately considered Edwards, who was then editor of Lux, a weekly Christian newspaper occasionally focusing on British imperialism in Africa. Lux also advertised Edwards' book, From Slavery to a Bishopric: A Sketch of the Life, Struggles, \& Successes of Bishop Hawkins in Fraternity. This 200 page book was published by Lux Newspaper \& Publishing Company as was United States Atrocities, a pamphlet written by Ida B. Wells, with an Introduction by Edwards. ${ }^{6}$ At this point of the anti-lynching campaign, Catherine Impey had temporarily suspended publication of Anti-Caste, and when Edwards agreed to accept the challenge of editing Fraternity, she "donated all of her material to him." The two appear to have maintained a helpful association in spite of the friction between Impey and Mayo. ${ }^{7}$

Billed as the "official organ of the SRUBM," the first issue of Fraternity was published in England in July 1893, just after Ida B. Wells' first visit and lecture tour in the region. The first page message from the editor

${ }^{5}$ Ware, Beyond the Pale, 193

${ }^{6}$ See most issues of Fraternity after 1894 for advertisements of these books.

${ }^{7}$ Ware, Beyond the Pale, 194. 
bore the title "Unity Our Aim," and proceeded to let it be known that Fraternity was taking up the work which Anti-Caste had begun by stating:

For more than six years, Anti-Caste has been doing a quiet work in England, slowly but surely permeating society, and winning the hearts of good men and true women to the cause of the struggling helpless races in America, India, Africa, and Australia, and where ever ... nations have been oppressed by the accursed enemy of mankind. ${ }^{8}$

It was made clear that the SRUBM was established as a reaction to information gained from Anti-Caste and was organized with the intent of "directing its attention to the work of removing inequality and wrongs from races whom we feel sure will, with greater opportunity and freedom, do as much credit to themselves as any nation in Europe."9

Edwards noted that the "last issue of Anti-Caste reached up to seven thousand," and expressed the hope of being able to not only maintain, but increase that number. The editorial concluded with a plea for news from home and abroad, and a "thank you" to the Bristol and Liverpool presses for endorsing their anti-racism efforts.

Just as with Anti-Caste, the primary focus in the initial stages of the

\footnotetext{
${ }^{8}$ Celestine Edwards, "Unity Our Aim," Fratenity, 1, no.1 (July 1893): 1.

${ }^{9}$ Ibid.
} 
journal was the problems of African Americans rather than the oppressed people of other countries. In addition to accounts of the horrific crime of lynching, there was also, by that time, an avalanche of useful information coming from America. The first issue of Fraternity included three articles devoted to American brutality and lynchings per se, as well as the following "warning" from the New York Age:

We warn the British public and its editors that the Southern newspapers and news associations are in league with Southern white public opinion to distort the facts of the race problem, to condone the rascalities of the mob, and to magnify the offences of black men charged with crime. Not every white woman who yells 'rape' has been raped against her will and not every black man lynched is charged with rape. Whatever may be the facts of the case, they should be ascertained and punished by the legal authorities and not by an irresponsible mob of 'the best citizens.' And no guilty man, be he rapist or mobocrat, ought to escape punishment. ${ }^{10}$

This reaction from the Age exemplified the awakening of the African American populace to the falsification of "rape charges" that whites overwhelmingly gave in defense of lynchings.

As leader of the SRUBM, Celestine Edwards quickly assumed the role of lecturing on lynchings that Wells, Impey, and others had initiated. On July 3, 1893, he spoke at the Bristol branch of the YMCA on the subject,

${ }^{10}$ Ibid., 2. 
"Lynch Law, or American Atrocities," to a large audience who considered him to be well informed on the topic at hand. The Jarrow Express covered a lecture that Edwards had delivered in Jarrow, describing him as "a coloured gentleman, who had visited Jarrow several times lecturing on Christianity and Atheism," but was at this event lecturing on "Lynch Law" in America. ${ }^{11}$

On August 14, 1893, Edwards delivered a speech in Birmingham titled "Black and White in America." Media reports noted that "every inch of the room in the building was occupied half an hour before the lecture commenced." As Edwards dramatically exposed American atrocities, "indignant cries of shame came from all parts of the hall." Similar speeches were regularly given by Edwards throughout the month of August, as was reported in the September issue of Fraternity. ${ }^{12}$

Edwards usually began his lectures by recapitulating the period of American slavery, which served as background information and a foundation from which to explain the condition of blacks during the postemancipation era. Noting that blacks, who were being "subjected to all kinds of disabilities, political, civil, and even religious," had also "over the

\footnotetext{
11 Irene, "Progress" Fraternity, 1, no. 2 (August, 1893): 16.

12 Irene, "Progress," Fraternity, 1, no. 3 (September, 1893): 14.
} 
past 26 years been murdered by whites, for which not one white man suffered the penalty of law."13

Often, Edwards confronted charges of inferiority, laziness, or dirtiness among African Americans, which were usually given by whites in defense of their promotion of white superiory. Edwards' reply to the charges was that "at the time of the abolition of slavery, there was no doubt that blacks were inferior to whites," meaning that "if A could read and B could not, then B was mentally inferior to A." But at the same time, he said "the majority of the white people were not superior to the blacks, because they knew no more about reading than a cow."14 To charges of laziness and dirtiness his reply was that:

After being in slavery for 300 years, ... he [the enslaved] was justly entitled to a holiday. The only fault of the black, however, was that he did not see the fun of working for nothing. Then as to the charge of being dirty, it was curious that the black was found cooking the victuals in all the restaurants, baking the bread and other things with which the white man filled his gizzard. ${ }^{15}$

Edwards commonly emphasized the disadvantages with which African Americans began their newfound freedom. "Starting out as free

\footnotetext{
13 See the early issues of Fraternity ( $1893-1895)$.

14 Irene, "Progress," Fraternity, 1, no. 2 (August, 1893): 16.

15 Ibid.
} 
people, but destitute mentally and socially, blacks had no wealth, no capital, and in millions of instances, did not know how much to charge for labour."16 This reference to labor, was likely associated with the new labor systems of tenant farming, contract labor, and sharecropping being instituted in the late nineteenth century as the economic alternative to slave labor. Lines of distinction were drawn in Edwards' lectures between the position of the slaveholder who had complete control of his slave property, and that of postbellum whites who believed that their position of authority was threatened by the advancement of blacks. The lectures concluded with "harrowing, blood curdling" accounts of "barbarous cruelties perpetrated on blacks," and an appeal to the audience to take a stand against the crimes. ${ }^{17}$

On Friday afternoon, August 11, 1893, a meeting of the SRUBM was held at Memorial Hall in London. Among those present at the meeting was Catherine Impey, who witnessed her diminished influence in the antilynching movement. At that meeting, a "summarization" of the previous meeting held in Birmingham (at which Impey does not appear to have been present) was given. Present at that meeting were: Rev. T. W. P.

${ }^{16}$ Celestine Edwards, "The Racial War in America," Fraternity, 1, no. 3 (September, 1893): 15.

${ }^{17}$ Ibid. 
Taylder, Miss Bishop, Mr. Glaister, Rev. H. M. Joseph, Rev. J. C. Street, Mr. E. S. Tregelles, Mr. W. A. Cadbury, Mr. S. A. Steinhal, Mr. D. Natoroji, M. P., Dr. C. Muthu, Mr. W. E. A. Axon, Mr. R. L. Impey, Miss Bishop, Miss. E. Wigham, Mrs. I. F. Mayo, Miss Robinson, Mrs. Clothier, Miss Metford, Mrs.Thompson, and Mr. S. J. Celestine Edwards.

What was discussed at the previous Birmingham meeting was crucial to the decline of Anti-Caste in that it was determined that, in addition to an Executive Council being established, "Anti-Caste would hereafter be superseded by Fraternity."18 Although Impey was certainly aware of this impending action, it must have been devastating to see the work that she had started be so abruptly taken over by others.

At the London meeting, the members of the SRUBM decided to rephrase the wording of a previously crafted declaration intended for all members of the Society. As part of this, the word "Universal" was removed from its name, the organization thereby became the Society For the Recognition of the Brotherhood of Man (SRBM). It was also affirmed that the declaration would eliminate all references to "Scripture texts," evidently

18 Celestine Edwards, "Report of Council Meeting of S R B M." Fraternity, 1, no. 2 (August, 1893): 13. 
attempting to prevent limitations in the scope of membership. The final agreed upon declaration read as follows:

I, the undersigned, promise to help in securing to every member of the human family, Freedom, Equality, Opportunity, and Brotherly Consideration. ${ }^{19}$

In relationship to the methodology used to reach its goals, the organization determined to send a circular to all potential financial backers. In anticipation of securing funds, Mr. E. S. Tregelles was appointed treasurer. The issue of receiving factual information was discussed, and it was decided that "trustworthy agents" would be sent to America, India, the West Indies, and other parts of the world. In addition, a "register," relative to incoming information would be kept "in order that thoroughly reliable information might be imparted to the Society upon questions in which it was interested." 20

Specific to America, members of the organization put forth the following suggestions: That a representative from the Society would go to America, collect information, report what he or she had learned from the experience, and then begin to lecture in the United Kingdom. This suggestion fits the

${ }^{19}$ Ibid.

${ }^{20}$ Ibid. 
pattern that had already been established by Wells, Impey, and Mayo, the lecture format being a reliable method of educating the public, receiving media attention, and public sympathy. The second suggestion for affecting change in America was that the Society would "appeal to President [Grover] Cleveland, notifying him of the outrages committed upon the coloured people, [and] asking him to use his influence to secure their discontinuance." 21

The SRBM concluded its new business with a resolution that would henceforth remain on the title page of each issue of Fraternity. The tenents of the resolution implied that the SRBM declare itself "fundamentally opposed to the system of race separation ... lynchings and other forms of brutal injustices inflicted on the weaker communities of the world." It also required its members to "refrain from all complicity in the system of race separation, whether as individuals or by co-membership in organizations which tolerate and provide for the same."22

The format of Fraternity was similar to that of Anti-Caste. It was a monthly journal dedicated to exposing inhumanity and utilizing written
${ }^{21}$ Ibid.
22 Ibid., 13-14. 
examples which supported its intended purpose of unity, equality, and universal brotherhood. Fraternity, however, was much lengthier than AntiCaste, averaging 15 to 16 pages per issue. This of course allowed for more varied information related to global oppression, but in the inital issues the cases of oppressed African Americans were most often presented as it had been in Anti-Caste.

One of the primary participants in this latter phase of the anti-lynching campaign was Florence Balgarnie, an English journalist and reformer. She had been very involved in feminist activites and belonged to suffrage and women's rights organizations. Having come in contact with the work of the SRBM as a journalist, she was propelled to become involved, and as a result, was elected secretary of the Anti-lynching Committee in $1894 .^{23}$

As secretary of the Anti-lynching Committee, Balgarnie was charged with much of its outgoing correspondence. One particular letter written by her was to the governor of Alabama in October 1894, in which she made the following appeal:

Sir - The Anti-lynching Committee, formed to protest against the lawless and murderous outrages called 'lynching' by which some regions of America have been disgraced, have heard with much concern that in the State over which your

23 Ware, Beyond the Pale, 218. 
Honour presides the murder of two negroes by a mob took place on August 24, according to telegrams received in London and a fuller account given in the Chicago Inter-Ocean of August 25. The story stated is that two negro murderers were carried off by a mob from a passenger train, hanged, and "while gaping their last," a volley of buckshot and bullets was fired into their bodies.

It appears almost incredible that such lawlessness can occur in communities supposed to be civilized, and it would be a great satisfaction to our committee, and we feel assured to all the friends of America in England could we receive assurance from your Honour that the alleged atrocity is unfounded. But should it unhappily be true, we feel constrained to express our horror of this and other outrages of the kind, whose inhumanity, law-lessness, and cowardice cannot fail to compromise the reputation of Americans generally, though we cannot suppose that honorable people in America are less shocked than ourselves at such events. ${ }^{24}$

A reply to Balgarnie's letter was written by the governor of Alabama's private secretary, J. K. Jackson, and was received by Balgarnie shortly afterwards. Essentially, the reply expressed surprise at having received such a reprimand from a foreign committee whose names included such distinguished people as "the Duke of Argyl and John McCarthy, M.P." Jackson pointed out England's oppressive relationship with Ireland, Egypt, and India, and noted that "laxity in administration of justice and protection of life, property, or morals anywhere in the British empire would not have been questioned by officials in America or other countries." After assuring Balgarnie and the anti-lynching committee that he and the governor

24 Florence Balgarnie, "Lynching in America," The Times, 6 October 1894, 7. 
abhorred mob violence, he made this statement about the interference of others:

There is today no more formidable hindrance to the complete enforcement of our laws, sustained as they are, by the power and thought of the vast body of our people in the class of cases to which you refer, than the attempt of a committee of British subjects to constitute themselves an international moral tribunal.$^{25}$

William Lloyd Garrison, Jr., son of the abolitionist, was moved to write a letter to the editor of The Times in response to Jackson's letter. Garrison reminded Jackson that it was not uncommon for "the downtrodden people of a nation to appeal for justice to the world's tribunal." To that end, he emphasized the assistance given by British abolitionists in the American anti-slavery movement and noted that "Lafayette's interference in England's treatment of her colonies" revered him to the American public. ${ }^{26}$ Garrison had recently expressed his outrage at lynchings in an anti-lynching meeting in Boston where he declared that:

The issue has developed into one of caste, not of race. If it were race antagonism the black nurse would not be cherished where her daughter fresh from college has no footing. Let the negro be content

25 J. K. Jackson, "Lynching in America," The Times, 6 October 1894, 7.

26 William Lloyd Garrison, "The Anti-lynching Committee," The Times, 9 November $1894,15$. 
to occupy the place of menial, he is liked and treated with friendly toleration, but whenever he attempts to cross the line, as he must, impelled by every impulse of manhood and progress, he must be made to know his place. This caste spirit is at the core of the murders and lynchings we are here to consider. ${ }^{27}$

What Jackson's letter did not take into account was that the English Anti-lynching Committee was a group of concerned humanitarians who assailed oppression not only of African Americans being lynched in America but also of the victims of English imperialism. They would have agreed with accusations against the British government and welcomed foreign intervention aimed at assisting their cause.

Florence Balgarnie's contributions to the anti-lynching campaign were chronicled in the June/July, 1895 issue of Anti-Caste. It was noted that she was "doing valiant service in the anti-lynching cause in England." It also mentioned the March 1895 article that Balgarnie had written on Ida B. Wells in Great Thoughts magazine and considered it to have been "an excellent portrait and character sketch" of the journalist. It was noted as well that Balgarnie had come to the rescue of Wells at the British Women's Temperance Convention, at which time an accusation was brought against her by Lady Henry Somerset, president of the British Women's Temperance

27 Catherine Impey, "The Editor's Annual Address," Anti-Caste, 7 (March 1895): 2. 
Association (BWTA). In an earlier incident, Lady Somerset had taken the side of Francis Willard, President of the Women's Christian Temperance Union of America (WCTU), when Wells had accused the organization of ignoring the inhumanity of the lynching mania in America. In an "eloquent and impassioned speech," Balgarnie vindicated Wells and stated that she thought that "American women too often apologized for, instead of denouncing outrages such as lynchings." She went on to make a plea for "American sisters to speak out more boldly in the matter."28

Balgarnie's relationship with the BWTA was further strained, when she, in an interview, challenged a statement made by the WCTU that Frederick Douglass had signed their resolution against lynching before he died in 1895. This gave the impression that Douglass had acknowledged the WCTU's stand against lynching. William Lloyd Garrison, Jr., and members of the African American community questioned the validity of the statement, and Balgarnie publicly challenged it in the British press. For doing so, Balgarnie was ousted from her committee position in the BWTA, dismissed from her post on the organization's newspaper, and boycotted as a lecturer. ${ }^{29}$

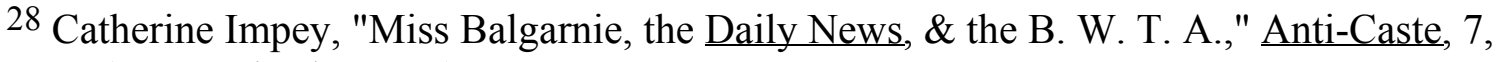
no. 6 (June and July, 1895): 6.

29 "Vidicated By His Widow," Fraternity, 3, no. 7 (July 1896): 5.
} 
In December 1895, Balgarnie received a letter from Helen Douglass, thanking her for sending copies of Fraternity and for defending her husband's name. She noted that Douglass "did not know of the resolution," and that "any impeachment of his integrity was an insult to his memory."30

Although Isabella Mayo's name was never attached to articles or letters in Anti-Caste, a letter that she wrote to American evangelist, Dwight L. Moody,appeared in Fraternity under the title "Mr. Moody and the ColourLine."31 Moody, along with Francis Willard, had been accused by Ida B. Wells of ignoring American lynchings rather than using their influence to denounce and make a clear statement against the crimes. Both Moody and Willard were highly admired in England. They had addressed numerous audiences promoting Christian ideals, and Wells' accusations were of great concern. Mayo's letter to Moody expressed disappointment in knowing that America's northern Christians had supported brutality and segregation by keeping silent. Mayo provided examples of northern preachers having been

30 Helen Douglass to Florence Balgarnie, 12 December 1895. Reprinted in Fraternity, 3, no.7 (July 1896): 5.

31 Celestine Edwards, "Mr. Moody and the Colour-Line," Fraternity, 7 (January 1894):

12. Note: The volume numbers and page numbers of some of the issues of Fraternity did not follow the pattern of initial issues. Also, certain articles did not bear the author's name, although they were probably written by the person acting as editor during that time. 
involved in decisions that were made to segregate certain religious meetings.

She specifically mentioned a meeting in the South in which blacks were refused admittance. Mayo concluded the letter by stating that:

Some of us in Great Britain have recently formed Society for the Recognition of the brotherhood of Man with the view of directing Christian teaching and example more to this great Christian doctrine, our neglect of which is sadly hampering the work of Christianity . . . As one of the founders of that Society, and in its name, I venture to appeal to you for information as to the accuracy of the reports I have quoted, that we may, if possible, put an end to the scandal and offense they cause. ${ }^{32}$

The following month, Fraternity printed a reply from Moody stating that "not a word of truth" was in the accusation. To receive further verification of the southern incident, Fraternity's editor, Celestine Edwards wrote to "two American journalists." The reply of one of them, T. Thomas Fortune, was used to refute Moody's statement. Fortune remembered well the incident in the South where Moody "was invited to hold a series of revival meetings." When Moody arrived in the South, Fortune recounted, he found that the committee that invited him had arranged for separate meetings for blacks and whites. Fortune assured Edwards that this was common in the South and that Moody was well aware of that before he went. Mr.

32 Ibid. 
Moody, Fortune stated:

Understood the situation roughly before he went South. What American does not know all about it? He went to Rome knowing the custom of the Romans, and conformed to them without any great deal of protest. Mr. Moody is as good as the average American Christian and no better; and taken as a whole they make me very tired. ${ }^{33}$

African American editors continued to send articles and letters to be quoted or published in their entirety in Fraternity just as they had done with Anti-Caste. Apparently, they did not view the rift between Impey and Mayoas an impediment to the cause and appear to have embraced the efforts of these committed crusaders. T. Thomas Fortune remained a consistent contributor, but more of his articles were written specifically for Fraternity rather than being reprints from the New York Age, as many of them had been in Anti-Caste. In October of 1893, he praised Fraternity for what it stood for:

A pillar of cloud by day and of fire by night, giving to the oppressed everywhere inspiration, even as Garrison's Liberator, that we feel in the midst of the unequal conflict of might against right. ${ }^{34}$

He encouraged the editors of Fraternity to continue its efforts because

${ }^{33}$ Celestine Edwards, "Mr. D. L. Moody and the Blacks," Fraternity, 8 (February 1894): 16.

34 T. Thomas Fortune, "Lynch Law Becoming More Common," Fraternity, 4 (15 October 1893): 1 . 
British publicity and opinion on lynchings had begun to have an effect in America. "The readers of Fraternity," he stated:

must know how sensitive American public opinion is to foreign criticism. This fact was accentuated for all time in our anti-slavery warfare. It has been accentuated anew by the rancour and brutality with which Southern newspapers denounced Miss Ida B. Wells, and the gospel of truth she lately preached in Great Britain. Without in the least undertaking to refute the awful story of which she was the eloquent messenger, they were shocked that the story should be told to British audiences and discussed in British newspapers. ${ }^{35}$

Fortune gave an example of American journalists responding to British publicity and exhibiting "an awakened sense of responsibility" by citing an article in The New York Voice, organ of the Prohibition Party. The particular article raised questions about the rape of white women, the alleged reason given for many lynchings, when in fact blacks were being consistently lynched for a wide variety of offenses. The Voice article "condemned lynch-law for any purpose as the means of justification," and made note that while most lynchings occurred in the South, the North was guilty of committing the crime as well..$^{36}$

35 Ibid.

${ }^{36}$ Ibid., 2. 
A follow-up to Fortune's November 1893 contribution to Fraternity was included in the December issue of the journal. It was intended as an up-date on the state of mob brutality in the United States, and began in the following manner.

Since my last letter to Fraternity we have had the usual record of mob violence, with fury and increased heinousness ... More startling still, the mob spirit appears to be widening its area of possession, becoming bolder, seeking new fields for the display of its destructive powers destructive alike for human life and the safeguards of law and order, evolved out of a thousand years of human thought, effort, and sacrifice. It is slowly dawning upon the thoughtful minds of the country that mob law is contagious, but still groping in darkness, hoping vainly for the light. ${ }^{37}$

To demonstrate the contagious nature of lynchings, Fortune pointed out three incidents that were setting a precedent by occurring in the western states, a region of the country in which lynchings had previously been uncommon. "The point being made," he stated, "that the Southern mob spirit is growing, and if not checked will cover the whole land, as the locusts of old covered Egypt."38

Again, as in the November article, Fortune attacked the accusation of rape as the reason for lynching by providing numerous incidents of

37 T. Thomas Fortune, "The Maddest Act of the Mob," Fraternity, 6 (December 1893): 2. 38 Ibid. 
lynchings whose motivations did not fall in that category. He also noted that the frequency of sexual assaults on African American females by white males did not generate any concern in the general populace or the judiciary system. $^{39}$

Fortune's up-dated article included an account of the foiled lynching of Phil Evans in Bardstown, Kentucky, which resulted in an attack on him and his family.

At 12 o'clock last night the home of Evans, two miles in the woods back of Samuels Station, was blown up with dynamite, a fusilade of shots fired for some unknown reason, and the fragments of the dwelling burned until nothing but a few bricks is left. The aged mother of Evans and his wife and daughter, though known to have retired last night, are nowhere to be found, and there is every reason to believe that they were blown to atoms. ${ }^{40}$

Fortune contrasted the silence of newspaper reporters regarding the Bardstown bombing to what he perceived as a multitude of reports on similar occurrences in other countries, asserting that:

A peculiar phase of this matter is, that while American newspapers shout themselves hoarse in the throat at every dynamite report flashed under the milky way from Dublin, Paris, or Madrid, they have appeared in the main to have

39 Ibid.

40 Ibid. 
entered into a conspiracy of silence on this Bardstown affair. ${ }^{41}$

Fortune concluded his up-date by mentioning an open letter that was being circulated by Albion Tourgee, announcing his intention to publish The National Citizen, a newspaper addressing "lawlessness and the denial of suffrage and manhood rights to Afro-Americans." Noting Tourgee's prominence as head of the National Citizen's Equal Rights Association, Fortune applauded his "honest, and effective work for justice and humanity." Because of Tourgee's concerted efforts in behalf of African Americans, Fortune believed that he had obtained "the ear of the American and British public," and felt justified in promoting the new newspaper venture as one that was "much needed."42 This letter was written and submitted to Fraternity shortly after Fortune had spent an evening in Chicago with Ida B. Wells and Frederick Douglass during the time of Chicago's Columbian Exposition..$^{43}$

Albion Tourgee remained a contributor to the English anti-lynching

${ }^{41}$ Ibid.

42 Ibid.

43 Ibid. Fortune noted also during this correspondence, the collaboration between WellsBarnett and Frederick Doulass on the pamplet co-authored by them and circulated during the Fair. The pamphlet titled "The Reason Why the Colored American is Not in the World's Columbian Exposition," was considered, by T. Thomas Fortune to have been satisfactorily received at the Fair. 
campaign by writing for Fraternity as he had for Anti-Caste and was often quoted or made reference to in the journal. One reference to him focused on a letter that Tourgee had written Gov. William McKinley of Ohio, regarding the lynching in that state of seventeen year old Rosco Parker. Governor McKinley brought the letter to the attention of the state House of Representatives on February 27, 1894, at which time he stressed Tourgee's dedication to the anti-lynching cause, by remarking that "it [was] a fact generally known that no one person living [had] worked harder or more incessantly against the lynch disease than [had] Judge Tourgee."44

Tourgee wrote to Governor McKinley because he felt it prudent to impress upon him the responsibility that he had as governor to protect all of the citizens of Ohio. The letter commenced as follows:

Hon. Wm. McKinley - Dear Sir, The attention which has been recently awakened by failure of a grand jury in Ohio to indict parties well known to be guilty of lynching, must have called attention to the remarkable spread of this alarming malady. In the decade 1882 to 1892 the increase of known fatal lynchings was more than 100 per cent; in 1882, 117, in 1892, 236. Last year the aggregate was a little less, only 208; but taking into account the enormity, publicity, and general aggravated character of the acts, the record may be said to be very little, if any, improved. ${ }^{45}$

44 Celestine Edwards, "Judge Tourgee Writes Gov. McKinley and the Editor of the Gazette," Fraternity, 10 (April 1894): 3. 
Tourgee went on to indicate other examples of increased lawlessness in general in the northern and southern states, as well as his perceived reasons for it and possible solutions for curbing the crimes. As a native of Ohio, Tourgee had a special interest in that state's affairs. He suggested that McKinley set a precedent and allow Ohio to "take the lead in prescribing an effective remedy for this American epidemic" as spelled out below:

First - That the legal representative of any person lynched in any of the state shall be entitled to recover from the county the sum of 10,000 dols., by action brought either in the county where the victim resided, or, in case the plaintiff shall make affidavit that he is afraid to bring the action in the county where the crime was committed, then in any adjoining county.

Second - That any such recovery shall be made a part of the next succeeding tax levy in the county, after judgement rendered against the same.

Third - That any person suffering violence or assault at the hands of a mob, if said violence amount to serious personal injury, shall have a right to action against the city, town, or county in which the same shall have been received, and upon proof of such violence inflicted by a mob, shall be entitled to recover not less than 1,000 dols.; and more if the jury shall find the injury to be of greater pecuniary damage to such person by depriving him of capacity to earn a livelihood by his labour.

Fourth - That in case the injury is not serious, but amounts to an assault by a mob, the party injured may have his action again [sic] the city or town, and upon proof of such violence shall recover not less than 200 dols., in any court having jurisdiction of an action for damage to the person.

Fifth - That any compromise or agreement of any representative

45 Ibid. 
of a person who may have been lynched to take less than the full amount of such penalty or recovery shall be void, and the parties to such pretended compromise and those seeking to procure it shall be liable to indictment and on conviction shall be imprisoned for one year. ${ }^{46}$

Tourgee's letter to McKinley also appeared in the Cleveland Gazette and generated significant responses in favor of amending Ohio's existing Civil Rights Law to address lynchings and mob related crimes.

Fraternity frequently reported on American lynchings. The very first issue described the brutal lynching of "Samuel Miller of Bardwell, Kentucky," whose alleged crime was murder. Although Miller professed his innocence, lynch law prevailed, and in addition to being hung, "the mob set fire to the platform" and continued watching "until nothing remained ... but a heap of ashes." 47 Unfortunately, the burning alive of lynching victims had begun to occurr in certain incidents, making the crime even more incomprehensible and heartless.

The December 1893 issue was typical of most during the first year of publication, in that numerous incidents of lynchings were cited. In this issue attention was given to the excessive number of lynchings occurring in the state of Louisiana. For example, there was the incident of Dave Jackson,

46 Ibid., 5.

${ }^{47}$ Celestine Edwards, "More Brutality in America," Fraternity, 1, no.1 (July 1893): 5. 
who was lynched in New Orleans because he had "defied arrest;" and "in September [1893] three Negroes were hanged at New Orleans because they were brothers of a murderer;" two men were "lynched for hog stealing;" and in Bossier Parrish, a "Negro was arrested and lodged in jail, from which he was taken in broad daylight, and hanged by citizens." 48

Lynchings in other American states were also cited in the December issue of Fraternity. One took place in Tennessee on November 4, 1893, when four members of one family, "three men and one woman," were lynched. The bodies of the Waggoner family were discovered "suspended from a tree beside the turnpike road." In this case, although the victims had not been accused of any definite offense, they were "suspected" of thievery. Two small children of "the murdered woman" were spared. ${ }^{49}$ In the February 1896 issue of Fraternity, a "lynching in Virgina" was recounted, and significant space was given to lynching in the article entitled, "Some Recent Cases of Lynchings."50 The article entitled "Judge Lynch in America," which noted the lynching of six men in Kentucky and criticized the unjust

\footnotetext{
48 Celestine Edwards, "Things As They Are And Should Not Be," Fraternity, 1, no. 6 (December 1893): 5.

${ }^{49}$ Ibid., 6.

50 "Some Recent Cases of Lynching," Fraternity, 3, no. 32 (February 1896): 103.
} 
character of lynch law was printed in the February 1897 issue of the journal. 51

To combat late nineteenth century stereotypical images of African Americans, both Anti-Caste and Fraternity included some of the successes and achievments of contemporary African Americans. This effort was much more obvious in Fraternity, where the editor highlighted educational, employment, and other advancements. The September 1893 issue gave an example of J. D. Baltimore, an instructor in metal work at the Coloured Manual Training School in Washington, for his accomplishments in metallurgy. Mr. Baltimore had begun working with crude metals as a young boy. In 1869, at age twelve, he "completed a model engine and boiler" which attracted a great deal of attention. At the suggestion of President Grant, Baltimore's talents were enlisted by the United States Navy where he was employed for twelve years. After leaving the Navy, he was made engineer of the Freedmen's Hospital in Washington before assuming his present position at the Training School. Fraternity noted a number of Baltimore's metallurgical accomplishments, in particular " his construction of an engine entirely of glass, by means of which his pupils were enabled to

51 "Judge Lynch in America," Fraternity, 4, no. 2 (February 1897): 90. 
study the internal movements of the locomotive."52

Another example was that of an African American physician on the staff of Provident Hospital, an African American facility in Chicago, who had performed a life saving operation. In this incident "James McCormick was stabbed in the heart in a Chicago drinking saloon," and taken to the hospital, where "the section from two ribs was taken out and the heart exposed." The exposure revealed that "the pericardium or covering of the heart" had been severely cut in the stabbing, and as a result, the heart had been wounded. Surgery involved stopping the flow of blood "by means of ligatures of catgut," washing out the pericardium and stitching up the wound.

It was noted that "such operations have been undertaken before, but so far as known, this is the first successful one on record."53 This article is likely a reference to the surgical operation that was performed by the African American surgeon, Dr. Daniel Hale Williams, on July 10, 1893. The patient was James Cornish, who fully recovered from the surgery. Williams,responding to the inability of African American doctors to use the

52 Celestine Edwards, "An Eminent Negro Metallurgist," Fraternity, 1, no.3 (September 1893): 8.

${ }^{53}$ Ibid., 7. 
facilities of Chicago hospitals, founded Provident hospital in 1891.54

In March 1894, the story was told of a young " Negro boy," in

Barnwell County, South Carolina, who had somewhat of a photographic memory in that, whatever he heard or visually observed, remained indelibly unaltered in his memory. At twelve years of age, he was looked upon as possessing:

the most remarkable memory of which the world has any record. He committed the entire book of Genesis to memory the other day in the space of three hours, repeating every chapter after reading it over once, and forgetting only some half dozen words from the first verse to the last. 55

The affluence of Charles P. Graves, a " Negro millionaire," and "one of the wealthiest coloured men in the United States," 56 was commented on, as was that of "ten coloured men in Virginia worth $\$ 25,000$, fifty [men] worth $\$ 10,000$, and many whose wealth is rated between three and five thousand dollars." 57 These few examples of upward mobility and intellectual acumen among certain African Americans are but a small sampling of those

${ }^{54}$ Kenneth Estell, African America: Celebrating 400 Years of Achievement (Detroit: Visible Ink Press, 1994), 683.

55 Celestine Edwards, "A Boy's Remarkable Memory," Fraternity, 1, no. 8 (March 1894): 7.

${ }^{56}$ Celestine Edwards, "A Negro Millionaire," Fraternity, 1, no. 6 (December 1893): 16.

${ }^{57}$ Celestine Edwards, "Industry and Trift," Fraternity, 1, no. 3 (September 1893): 7. 
mentioned over the course of Fraternity's existence.

It was important to the SRBM to make a statement about African American equality. In America, racial attitudes and literature were replete with negative images of Africans and African Americans in justification of lynchings and other forms of discrimination. In England at this time, there was a mixture of attitudes towards members of the African diaspora, contrasting significantly with earlier humanitarian gestures, especially during the abolitionist era. Attitudes ranged from genuine efforts to assist and uplift -- as was evidenced by religious and humanitarian groups, -- to extreme hostility, racial prejudice, and Social Darwinist ideals. Edward Scobie, author of Black Britannia: A History of Blacks in Britain, believes that the change in attitude "coincided with an increase in the frequency of contacts with blacks in the West Indies and other colonies" as a result of imperialistic expansion. ${ }^{58}$ However, Ida B. Wells' experience in England during this time period did not reflect the new development. She had nothing but praise for the unprejudiced treatment that she received from the English. 59

58 Edward Scobie, Black Britannia: A History of Blacks in Brittain (Chicago: Johnson Publishing Company, 1972), 135.

59 Duster, Crusade For Justice, 212. 
In spite of references made to growth in readership and greater acceptance of its principles, the SRBM's Fraternity was a struggling publication venture. After Mayo withdrew her financial assistance from Ida B. Wells' second lecture tour, she made only limited contributions to the cost of printing Fraternity. This does not appear to have been a particular disadvantage during the first year of publication due to the fact that Celestine Edwards, as editor, had assumed the primary financial responsibilty of producing the journal. Edwards, however, became severely ill from a lung condition in the spring of 1894, at which time he went back to Dominica to be with family and died on July 25 of that year. ${ }^{60}$

Edwards had taken "all financial risk and loss [for Fraternity] upon himself," and the cessation of his input was immediately felt, as evidenced by the repeated appeals for financial assistance and expressions of concern for the continued printing of Fraternity. The cost per issue was only one penny, and the organization was often encouraged to increase that amount in order to cover expenditures, but the cost was purposely kept low to remain affordable to everyone, as had been the policy with Anti-Caste. ${ }^{61}$

${ }^{60}$ Mary A.. M. Marks, Fraternity, 1, no. 14 (August 1894): 5

61 "What We Think," Fraternity, 1, no. 13 (July 1894): 1. Also "In Memoriam," 
One concerned member of the SRBM, in a "Letter to the Editor," made several suggestions for balancing the books, and expressed concern that accounts of "receipts and expenditures" had not been sufficiently revealed. A reference was then made to Wells' 1893 tour:

Many who contributed liberally to Miss Ida B. Wells' Mission last year can have seen no public acknowledgement of their gifts and how they were laid out. As to the methods of Miss Wells Mission this year, we are kept wholly in the dark. ${ }^{62}$

When this letter was printed in the journal, Celestine Edwards was on sick leave in Dominica, but was expected to return. Under that assumption, the author of the letter noted that, as a Member, he or she would send "a special 2 shillings a month for Fraternity until Editor returns." 63

Few immediate changes were made in the organization or its organ after Edwards' death. The new editor, Mary A. M. Marks, announced that "the SRBM was carrying on its work precisely as it has always done." Until permanent officers could be elected, Isabella Mayo and George Ferdinands, Esq., M. D., would temporarily serve as president and vice president,

Fraternity, 1, no. 15 (September 1894): 3.

62 An Original Member, "Letter Box: To the Editor of Fraternity," Fraternity, 1, no. 13 (July 1894): 15.

63 Ibid. 
respectively. It was also resolved that "ownership of Fraternity would be vested in the editor for the time being." 64

The SRBM does not appear to have published Fraternity in 1895, which may account for Catherine Impey temporarily resuming publication of AntiCaste during that year. Fraternity became available again in January 1896, and although there were some articles related to the discrimination of African Americans, the orientation on lynchings and African American concerns no longer dominated the publication. Fraternity, and evidently the SRBM, had acquired a new focus. The difference was reminiscent of the abandonment of African Americans by the Republican Party after Reconstruction, but the reality was that the mission had been accomplished in terms of the raison d'etra for anti-lynching agitation in the United Kingdom. Wells-Barnett had come and gone and the impact had been made in America.

In the 1890s, the British social and political environment was in transition. In addition to changes in racial attitudes as mentioned above, political changes in Britain would initiate varied responses within the

64 Mary A. M. Marks, "The Present Position of Our Society," Fraternity, 1, no.15 (September 1894): 5-6. 
populace. The January 1896 [comeback issue] of Fraternity carried a front page article stating that "1895 will be remembered in history as the year of the General Election, which returned the largest Conservative majority-- the largest indeed, far larger than that which carried the Reform Bill of 1832."65 This article was in reference to the transfer of governmental power from Prime Minister Archibald Rosebery in 1895 to Lord Salisbury. Rosebury had succeeded William Gladstone as prime minister when Gladstone retired in 1894. Rosebury's defeat in 1895 handed governance by the Liberal Party to the Conservatives under Salisbury. For the first time in fourteen years, the Conservatives were in control again, and with the approval of the monarchy which was under the long-standing rule of Queen Victoria. ${ }^{66}$ It was further noted in the article that Fraternity did not concern itself with "the purely political aspect," but with awakening "the Christian conscience of England to the vast influences and responsibilites, religious, political, moral, [and] commercial, of the thing called the BRITISH EMPIRE." In spite of that declaration, there was an undeniable political emphasis to this phase of Fraternity's existence. ${ }^{67}$

${ }^{65}$ Mary A. M. Marks, "Retrospect," Fraternity, 3, no. 31 (January 1896): 1.

${ }^{66}$ Antonia Fraser, The Lives of the Kings and Queens of England (London: Weidenfeld and Nicolson, 1975), 308.

${ }^{67}$ Marks,"Retrospect," 1. 
Wells-Barnett included detailed summaries of the historical traditions of the various British towns that she had visited in her autobiography, but she gave little attention to the social and political climate of contemporary England, which by the 1880 s and 1890s had become a conducive environment for the trade union movement, Fabian dominated socialism, and anti-imperialist sentiment. 68

The nineteenth century phase of British labor history was characterized by the innovations and evolution of the Industrial Revolution and efforts by the working class to bring attention to their concerns. The early demands of the working class were enunciated through the Chartist Movement in the 1830 s and 1840 s. Representing the first, "organized, mass working class movement in British history," the Chartists sought equal political rights which included: equal electoral districts, universal male suffrage, vote by ballot, and "the abolition of property qualifications for members of Parliament so that the poor could seek election."69

By mid-century, British politics moved toward economic liberalism and a

68 Kenneth D. Brown, The English Labor Movement, 1700-1951 (New York: St. Martins Press, 1982), 165.

69 Ibid., 91. 
policy favoring free trade. This adjustment to the population demands of industrialization called for a repeal of the Corn Laws which had facilitated agrarianism. The repeal "made possible the importation of low-priced grain, cheaper food for the masses, and a more contented labor supply for the factory owner."70 Under these conditions, the British economy flourished, which had the indirect effect of stimulating the growth of unions. Encouraged by a successful strike of "north-eastern engineers to secure a nine-hour day in 1871, " unions of unskilled laborers began to organize in rapid succession. ${ }^{71}$

Late nineteenth century socialism in England presented itself in a "variety of guises, revolutionary or social-democratic, utopian or Fabian."72 The Fabian Society, however, represented the most prominent Socialist group in Britain in the 1890s -- the decade of Fraternity's existence. Organized in 1884, it was primarily responsible, along with support from trade unions and other socialist groups, for the formation of the Labour Party in 1900. The Fabian's brand of socialism was not overwhelmingly influenced by the

\footnotetext{
70 T. Walter Wallbank, Alastair M. Taylor, George F. Jewsbury, Clyd J. Lewis, Neil Hackett, Civilization Past and Present (London: Scott Foresman and Company, 1987), 636.

${ }^{71}$ Brown, English Labor Movement, 165.

72 Wallbank, Civilization Past and Present,
} 
doctrines of Karl Marx. Adherents generally "placed their faith in Parliamentary reform." This was evident as they supported the British Empire when the Boer War began in 1899, not because they totally sanctioned imperialism, but because they intended to influence the government in the direction of their beliefs. ${ }^{73}$

Fraternity's latter issues (1896-1897) are filled with references to labor conditions and advertisements for socialist literature such as The Labour PROPHET by John Trevor and new establishments such as the Labour Press Society. The journal affirmed its socialist leanings by choosing Caroline D. Martyn as one of its succeeding editors in 1896. Martyn, who had declared her membership in the Fabian Society in 1891, demonstrated the Fabian's non-adherence to total Marxian philosophy by also becoming editor of the Christian Weekly in 1893. A former teacher, Martyn became during this time "well known through England and Scotland, not only as a speaker, but as a writer in many of the papers dealing with Labour

73 Bernard Porter, Critics of Empire: British Radical Attitudes to Colonialism in Africa, 1895-1914 (London: MacMillan, 1968), 109; British economic and political interests in South African Boer republics - the Orange Free State and the Transvaal, and especially after the discovery of gold in the Transvaal in 1885, led to war between the British and the Boers in October 1899. For further details on the Boer War, see Bernard Porter, "A Limited Area of Heather Alight," in The Lion's Share: A Short History of British Imperialism (London: Longman, 1976). 
matters." 74

When Martyn accepted the editorship of Fraternity, she had already been elected to the National Administrative Council of the Independent Labour Party and was on the verge of becoming Trades Union Organizer for northern Scotland. An original member of the SRBM, her strength of conviction and oratorical skills soon became apparent to Isabella Mayo, who wrote a glowing editorial of her in Fraternity, emphasizing a new direction for Fraternity under Martyn's editorship. Circumstantially, Martyn's service as editor was brief, due to her death just weeks later. She was succeeded as editor by Frank Smith, who had left a "flourishing business" to work with the Salvation Army, one of the humanitarian organizations working to solve England's 1890 s social problems. ${ }^{75}$ It was noted in Fraternity that Smith was also co-author of Darkest England and the Way Out, a book that, according to historian Bernard Porter, was inspired by Henry M. Stanley's, In Darkest Africa. ${ }^{76}$

\footnotetext{
74 Isabella Fyvie Mayo, "Our New Editor: Caroline Martyn," Fraternity, 4, no. 1 (July 1896): 7 .

75 Ibid.

76 "Fraternity Notes," Fraternity, 3, no. 2 (August 1896): 30; According to Fraternity, Frank Smith "laid the foundation of the Social Wing of the Salvation Army, the culmination of which was Darkest England and the Way Out." It is asserted in Fraternity, that although the book bears the name of General Booth, it was produced by the joint effort of Frank Smith and W. T. Stead, author of If Christ Came to Chicago, and
} 
During the Berlin Conference of 1884-1885, a significant portion of the African continent was "partitioned" between European countries who were "scrambling" for pieces of the colonial pie. Although Britain had long been involved in the acquisition of colonies in various areas of the world, "imperialism in the late nineteenth century, generally meant Africa; this is where the imperial drama of the 1880s and 1890s was acted out."77 By 1884, the British had gained control over certain African territories, the South African Cape Colony and Egypt were the most signifcant, economically, politically, and strategically. In fact, it was Britain's presence in Egypt as well as Belgian's acquisition of the Congo that motivated the German Chancellor, Otto Von Bismarck, to assemble delegates for the Berlin Conference. As a result of power politics between national rivalries and the move to exploit the continent's resources, Britain substantially increased its African colonial holdings. ${ }^{78}$ These developments spawned fervent pro-Empire support as expressed through jingoism, as well as

editor of Review of Reviews. See "Fraternity Notes," Fraternity, 3, no. 2 (August 1896): 30. Also see Porter, Critics of Empire, 140.

77 Porter, Critics of Empire, 1-2.

78 Colin Newbury, "Great Britain and the Partition of Africa, 1870-1914," in Andrew Porter, The Oxford History of the British Empire, Vol. 3 The 19th Century (Oxford: Oxford University Press, 1999), 624. 
significant anti-imperialist sentiment. ${ }^{79}$ As humanitarians and defenders of the oppressed, the members of the SRBM were repulsed by "Jingo fever," which in their opinion had attacked society in such a way as to touch even "altruistic men and women with its baneful influence." 80 Motivated by antimilitatistic principles, the SRBM passed two resolutions in May 1896, stating the SRBM'S positon on warfare and imperialism. The first resolution, expressed the organization's "conviction that aggressive warfare was diametrically opposed," as it compromised the organization's spiritual and religious beliefs. The second resolution specifically attacked England's imperialistic stand in Africa, noting that:

This meeting laments the present outbreak of 'jingoism' in this country, and deprecates the policy which has led to the numerous expeditions now on foot for the partition of Africa. ${ }^{81}$

In 1896 and 1897, Fraternity began to reflect the SRBM's interest in these movements and the British political environment in general. During this period, they changed the name of the organization from the SRBM to The International Society For the Recognition of the Brotherhood of Man

79 Porter, Critics of Empire, 35.

80 Mary A. M. Marks, "Report of Meeting," Fraternity, 3, no. 1 (June 1896): 148.

81 Ibid. 
(ISRBM), and broadened their focus to include local concerns as well as the impact of colonial expansion on African people and the continued oppression of people of color throughout the global community. ${ }^{82}$

There is no indication that Fraternity or the ISRBM survived beyond 1897. The organization and the journal had been founded as a link to the work that Catherine Impey and Anti-Caste had initiated. Whereas AntiCaste was the first English journal to expose lynchings beyond American boundaries by including it in its over-all protest of oppression, Fraternity was specifically created for the expressed purpose of addressing lynchings in America. The journal never fully recovered from the loss of its vital editor, Celestine Edwards, whose financial input and conviction to the ideals of the organization had significantly aided Fraternity's initial success. It had however, succeeded in fueling the anti-lynching movement and keeping it alive until the American response began to be heard.

${ }^{82}$ Ibid. 


\section{Conclusion}

Current research trends relating to the trans-Atlantic aspect of the nineteenth century anti-lynching campaign focus on the year 1892 as an originating date for the movement. However, as revealed in this study, that date identifies the point in time when Ida B. Wells-Barnett, as a catalytic force, began to make her mark on an already developing movement. By 1892, the initial trans-Atlantic connection of the movement had already been made. It has been shown that the movement originated during the decade of the 1880 s with the agitation of American anti-lynching protestors, who were joined in their efforts by the English reformer Catherine Impey. It was at that time that the trans-Atlantic connection began to develop and evolved into three distinct phases as represented by the years 18831891; 1892-1894; and 1894-1900.

As early as 1883, Catherine Impey sought out Frederick Douglass and offered her help in the struggle for African American equality. She had the notion that the British could serve as a "moral arbiter" as they had in the abolitionist movement. During America's antebellum period, fugitive slaves, viewed as "symbols of determination and hopes destroyed," were "received with opened arms" in the United Kingdom. They accepted British philan- 
thropic assistance and utilized opportunities to plead their case in England, which greatly assisted the abolitionist cause. ${ }^{1}$

Catherine Impey's Quaker upbringing had exposed her to the intricacies and successes of the abolitionist struggle. She grew up aware of Quaker involvement in the movement and was in awe of Frederick Douglass, about whom she had heard so much. Who else but Douglass, the prime example of abolitionism, would Impey seek out for approval and advice? She had been raised on stories about his experiences as an enslaved person, his sojourn as a fugitive in the United Kingdom, and the philanthropy and assistance that he had recieved from Quakers and their network of English friends. In England and elsewhere, Douglass was still greatly respected and remembered for his character, intellect, and atypical oratorical skills.

The Quaker tradition of assisting the downtrodden fueled Impey's inclination toward reformation. As with Douglass in America, there were also members of the Quaker community and others still living in the United Kingdom, who had been associated with the antislavery movement. Eliza

${ }^{1}$ R. J. M. Blackett, Building An Anti-Slavery Wall: Black Americans in the Atlantic Abolitionist Movement, 1830-1860 (Ithaca: Cornell University Press, 1983), 8. 
Wigham, for example, who had been a friend of Douglass' and a key person in Scotland who was involved in the abolitionist struggle and who was also a supporter of the anti-lynching movement. Another example is that of former abolitionist Ellen Richardson, who purchased Douglass' freedom in 1846 so that he could return to America. Richardson had granted Ida B. Wells an interview while she was in Newcastle, and although Richardson was in her declining years at the time, she remained a source of support and inspiration to members of the anti-lynching campaign. ${ }^{2}$

In addition to the impetus that Impey received from her religion, she was also part of the web of feminist reformers associated with the temperance and suffrage movements -- movements, whose vitality and evolvement rested in the efforts of the female dynamic which Impey represented. It is very likely that she received significant motivation and inspiration from the examples of female leaders and participants of these and other movements. The foundations which were laid by early reformers like Lucretia Mott and Elizabeth Cady Stanton, spawned a "matrix" of international sympathy and connectedness among reform minded women, which strengthened their convictions and sustained their specific endeavors. ${ }^{3}$

2 Ida B. Wells to Helen Douglass, 26 April 1894, Ida B. Wells Papers, Special Collections, Reggenstein Library, University of Chicago. 
Impey received her first glimpse of African American oppression when she traveled to America in 1878. During that time, she visited the "New York Coloured Mission" and was struck by the destitute state of African Americans who "daily crowded their doors." She was also saddened by the unequal educational and employment opportunities which American society offered for their advancement. ${ }^{4}$

On subsequent trips to America, Impey's awareness of the dire conditions that American blacks faced increased, and she became consumed with a desire to make a difference. During her visits, she met with former abolitionists and other American agitators who were already known for their anti-discrimination efforts. A circle of friends and aquaintances was created in America which initially included such personalities as Frederick Douglass, T. Thomas Fortune, Albion Tourgee, Fannie Jackson Coppin, William Lloyd Garrison, Jr., and William Wells Brown. Through Impey and this core of American activists, a trans-Atlantic connection was engendered. In 1888, Impey began the publication of Anti-Caste, the journal that

\footnotetext{
3 See: Margaret H. McFadden, Golden Cables of Sympathy: The TransAtlantic Sources of Nineteenth Century Feminism (Lexington: University Press of Kentucky, 1999), for insight into the international communicative network generated by female activists of the nineteenth century.

${ }^{4}$ Catherine Impey, "New York Coloured Mission," Anti-Caste, 1, no.2 (April 1888): 1.
} 
facilitated her need to assist, and the means by which a greater percentage of the global community became aware of lynchings.

Impey's offer to help was welcomed by Americans whose anti-lynching and anti-discrimination efforts had been ineffective. They recognized the advantage of having an intermediary outside of the United States working in behalf of the cause. Therefore, when Impey launched Anti-Caste, those Americans supplied her with the information needed to enlighten the international community on the injustices and atrocious crimes occurring in America.

These neo-abolitionists were humanitarians and social activists, nourished by the same passion for justice which had inspired the abolitionists of the antebellum period. Some of them like Douglass had remained active since that era or had, like Garrison inherited a social activist legacy, ${ }^{5}$ or as with Fortune and Tourgee were simply too bothered by the many examples of cruelty to remain silent.

T. Thomas Fortune, by the 1880 s, had begun to editorialize and organize to combat the rising tide of lynchings and other race related problems in

\footnotetext{
${ }^{5}$ For a discourse on this subject, see: James M. McPherson, The Abolitionist Legacy: From Reconstruction to the NAACP (Princeton: Princeton University Press, 1975).
} 
America. Fortune was one of the first to address lynchings in the initial phase of the anti-lynching movement (1883-1891). Believing that solutions were connected to African American unity and political strategy and empowerment, he organized the Afro-American League as a means of achieving those goals. As the influential "Dean of the Afro-American press," his reformist tendencies were unveiled in his own newspapers, the New York Globe, the New York Freeman, and the New York Age. ${ }^{6}$ Correspondences between Fortune and Catherine Impey and the editorial contributions that he made to Anti-Caste and Fraternity established his vital role in the international aspect and the first phase of the nineteenth century anti-lynching movement.

Although a champion of equal rights in his own community of Greensboro, North Carolina, Albion Tourgee's visibility accelerated with the publication of his novels, A Fool's Errand and Bricks Without Straw, both of which accentuated the unfortunate circumstances of southern American blacks and the failure of Reconstruction initiatives. Tourgee's writings, particularly the publication of A Fool's Errand in 1879, had an effect similar

\footnotetext{
${ }^{6}$ For details of Fortune's rise to this distinction and his establishment of the AfroAmerican League, see: Emma Lou Thornbrough, T. Thomas Fortune: Militant Journalist (Chicago: University of Chicago Press, 1972).
} 
to that of Harriet Beecher Stowe's Uncle Tom's Cabin in 1852, in that it exposed southern American practices to a trans-Atlantic community. Once Tourgee left the South in 1879 , he had greater freedom to refrain from anonymity as author of $\underline{A}$ Fool's Errand and began to be even more vocal on political and civil rights issues, which is evident from his articles in the Chicago Inter-Ocean and his establishment of the Citizen's Equal Rights Association. Tourgee's novels were already receiving international attention. However, his opinions and suggestions for banishing lynchings and improving social and political rights for blacks were put forth by Impey in Anti-Caste for greater international scrutiny. The influential political role that Tourgee played amongst African Americans in North Carolina during the Reconstruction period, his verbal attacks on the violence of the $\mathrm{Ku}$ Klux Klan, and his published writings during the 1880 s placed him at the genesis of the movement.

As anti-lynching / anti-discrimination efforts increased, more Americans and significantly more Britons became associated with the developing movement. Contributions to Anti-Caste in the form of subscriptions, articles submitted, distribution outlets, and comments and editorials related to the cause serve as testimony for the journal's effectiveness in increasing awareness and gaining anti-racist support. 
The anti-lynching movement solidified when the journalist Ida B. WellsBarnett began in her editorials to examine motivations for lynchings in 1892 after personal friends were lynched in Memphis, Tennessee. That lynching awakened Wells-Barnett to the fallacy of accusations connected to the crime. Previously having considered the possibility of lynchings being justified for alleged crimes of murder and rape, she knew, in the case of this particular lynching, that the victims were innocent of any wrong doing. ${ }^{7}$ Wells-Barnett's intervention into the nascent movement was significant and vital to its development. Her approach added the dimension of investigation, which appropriately shifted the blame for the crime from suspected African Americans to the lynch mob.

The three publications which Wells-Barnett wrote on lynchings, Southern Horrors: Lynch-Law in All Its Phases (1892), A Red Record: Tabulated Statistics and Alleged Causes of Lynchings in the United States, 1892, 1893, 1894 (1895), and Mob Rule in New Orleans (1900), are prime indicators for the various phases of her investigative research. In Southern Horrors, she recounted the Memphis lynching in detail and outlined the

\footnotetext{
${ }^{7}$ Alfreda Duster, ed. Crusade For Justice: The Autobiography of Ida B. Wells (Chicago: The University of Chicago Press, 1970), 47.
} 
solution to the crime as she perceived it. That was at the beginning of her inquiries into the many lynchings that she investigated. As she acquired evidence which was supported and cross-referenced by statistics in the Chicago Tribune and other reliable sources, she was able to synthesize

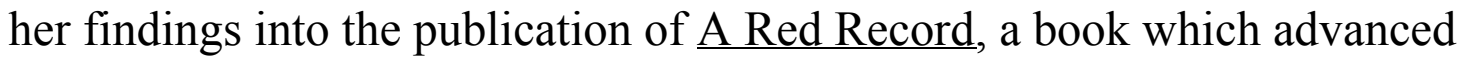
her theory about the causes of lynchings and strengthened her appeals in the American North and in England. Whereas public opinion among whites focused on African American brutality as a justification for lynchings, Wells-Barnett's investigations, as revealed in A Red Record, emphasized the fallacy of those allegations. As stated by Henry Louis Gates and Cornell West in The African American Century: How Black Americans Have Shaped Our Country, Wells-Barnett's A Red Record, "demystifies the myth of the lascivious black male who raped virtuous white women, and confronts the white community about the psychological basis of their fear of black sexuality."8 Her hope with $\underline{\text { A Red Record was that Americans would }}$ become outraged by the overwhelming prevalence of lynchings and the unfairness of lynch-law, then begin to take steps toward reforming the judicial system and punishing the lynchers. When Wells-Barnett wrote Mob

\footnotetext{
${ }^{8}$ Henry Louis Gates, Jr. and Cornel West, The African American Century: How Black Americans Have Shaped Our Country (New York: The Free Press, 2000), 37.
} 


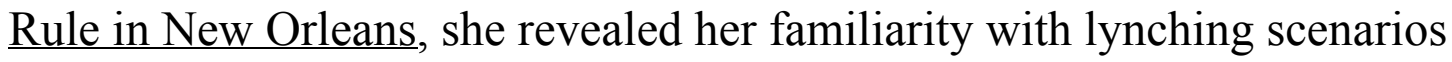
and the reliability of her investigative method, which allowed her to take an incident such as that of Robert Charles, an African American victim fleeing a mob and an impending lynching in New Orleans, and recount it with detail and clarity in the publication. ${ }^{9}$

The unjust character of the crime of lynching had already been expounded upon by the earlier agitators who protested "lynch-law" and suspected the erroneousness of the allegations, but Wells-Barnett's exile from the South at a time when lynchings were accelerating, placed her in the forefront of the movement where, as a catalytic force, her impact began to be felt.

Wells-Barnett's indictment of lynching was immediately noticed by Catherine Impey, who, along with Isabella Fyvie Mayo, brought WellsBarnett to the United Kingdom to further enlighten the region on the lynching phenomenon taking place in America. At that time, Wells-Barnett embarked on a lecture tour in Scotland and England, and the Society For the Recognition of the Brotherhood of Man (SRBM) was formed. Wells-

${ }^{9}$ See the reproductions of these publications in Ida B. Wells, On Lynchings (Salem: Ayer Publishing Company, 1993). 
Barnett's vivid description of lynchings in America attracted such Britons as Rev. Charles Aked and journalist and reformer Florence Balgarnie to the cause. Anti-lynching committees were created, and several churches and organizations resolved to denounce lynchings.

The establishment of the SRBM in the United Kingdom, represented a move which took the anti-lynching campaign beyond the initial efforts of Impey and Anti-Caste. The organization, established in 1893, was meant to facilitate Wells-Barnett's lecture tour and promote universal brotherhood. When Wells-Barnett left the United Kingdom in 1894, the SRBM, headed then by Isabella Mayo, and Fraternity, and edited by Celestine Edwards, became the mainstay of the British anti-lynching movement.

Under Edwards, Fraternity became a worthy successor of Anti-Caste. Edwards, who had been an admirer of the work that Impey had done with Anti-Caste, followed her example in producing Fraternity. During his editorship of the journal, the problem of lynching was repeatedly addressed, and the Americans who had supported Impey and Anti-Caste continued to support and make contributions to Edwards and Fraternity. Clearly, in this final phase of the British anti-lynching campaign, from approximately 1894 to 1897 , the SRBM and Fraternity were in concert with each other. By 1897, the trans-Atlantic dimension of the anti-lynching movement 
had ended. The pressure placed on Americans by the British and Scottish promoters of the cause was no longer necessary. As Impey noted in the January 1890 "Supplement" to Anti-Caste, she had:

been stating points of the colour question on which we English can and ought to act ... But the work, as a whole and finally, can only be done by Americans themselves. ${ }^{10}$

The American component to the nineteenth century anti-lynching movement became more of an entity as the international connection diminished. When Wells-Barnett returned to America she was well received by the African American community, who was anxious to greet her and show their gratitude for the work that she was doing. She made a similar anti-lynching lecture tour in America, and churches and other organizations began to make resolutions denouncing lynchings. As head of the antilynching committee of the Afro-American Council, Wells-Barnett launched a fund-raising campaign to aid the committee's investigative efforts. And although Frederick Douglass had died in 1895, Fortune, Tourgee, Garrison, Bishop Alexander Walters, members of the Afro-American Council, and others continued to press American officials and make appeals to American

10 Catherine Impey, "Editor's New Year's Address," Anti-Caste, 3, no. 1 (January 1890): 6. 
citizens that would hopefully lead to the cessation of lynchings.

As an African Amerian female, Wells-Barnett was an anomaly who had a powerful impact on the anti-lynching movement. As a confrontationist, she stepped outside of her expected sphere of operation. In the late nienteenth century, American society defined the role of women as one in which civic duty was confined to the realm of community uplift, to be carried out through the agency of the church or women's clubs. Ironically, Wells-Barnett's association with the evolving women's club movement occurred at an engendering moment, when that movement overwhelmingly responded to the unifying issue presented by Wells-Barnett and the antilynching cause. As African American women, they could also identify with Wells-Barnett's victimization by the white community, and were encouraged to unify, not only to rectify the reputation of African American males in relationship to lynchings, but also to strengthen the image of African American females.

In contrast, Wells-Barnett's confrontationist approach naturally conflicted with the assimilationist position of many African Americans who were not inclined to speak out against lynchings. By calling into question the motives of white lynch mobs, her anti-lynching agenda presented a threat to the security of blacks, particularly those in the South. That made it difficult to 
obtain their approval at the beginning of her campaign, even though she had the endorsment of respected males such as Frederick Douglass and T. Thomas Fortune.

The image of a victimized African American female who had been exiled from the American South, very likely had some influence on the positive response that Wells-Barnett received in the United Kingdom. Those audiences were also obviously impressed with her eloquence and sincerity as a speaker. However, those characteristics, influential as they might have been, had a limiting impact on the outcome of the movement. It was the message rather than the messenger that was most significant in inspiring the outpouring of sympathy for oppressed African Americans. That message began to be delivered in the United Kingdom in 1888 when Catherine Impey published Anti-Caste. Wells-Barnett had not yet become involved in the movement, and information in the journal regarding lynchings was received through others such as T. Thomas Fortune, Albion Tourgee, and Frederick Douglass. Their editorials had a significant impact during that initial phase of the movement and continued to be influential during the latter phase when Fraternity replaced Anti-Caste. Therefore, even though the pace of the anti-lynching movement was quickended when Wells-Barnett 
became involved, her impact on the movement was more reflective of her having been directly victimized in the South, the results of the methodology which she employed, and her sincerity and integrity, and less relative to her race and gender.

The cooperative effort that was established between American agitators and humanitarians in the United Kingdom during the nineteenth century anti-lynching movement stood on the foundation that was created during the abolitionist movement. Later, those past associations aided the perception of European countries as less restrictive environments for African American liberal expressions. As a result, African American scholars, and artists in all genres, found cities such as Paris and London to be conducive to artistic and political freedom, and educational advancement .

In the United Kingdom, the abolitionist legacy attracted others involved in movements to equalize the status of people of color in America and other parts of the world. They were "pulled" to the region by the reputation that had been established and by the link with the humanitarian element which still existed. W. E. B. DuBois and his pan-African movement tapped into it in 1923 when the second Pan-African Congress was held in London, England and Lisbon, Portugal.

Initial receptivity for the pan-African movement occurred in France under 
the influence of Blaise Diagne, the Senegalese member of the French Chamber of Deputies. Diagne's influence resulted in Paris being designated the location of the first Pan-African Congress in 1919, despite vehement opposition from the United States. Although a great deal of the receptivity for the pan-African movement in England was generated by African students studying there, the movement also attracted British trade unionists, socialists, and supporters of the new Labour Party; the type of people who by 1896 were recognizable in the anti-lynching movement as editors of Fraternity and members of the International Society For the Recognition of the Brotherhood of Man. The second Pan-African Congress attracted such British personalities as author H. G. Wells and socialist Harold Laski. The movement also received written endorsement from Labour Party leader, Ramsey MacDonald. ${ }^{11}$

In 1945, the fifth Pan-African Congress was held in Manchester, England as a result of a motion made by black labor leaders who had attended the International Trades Union convention in Paris during the previous month. That meeting is considered by historian Manning Marable to have been "a

${ }^{11}$ Manning Marable, W. E. B. DuBois: Black Radical Democrat (Boston: Twayne Publishers, 1986), 105. 
pivotal event in black political history," due to the attendance of a large number of key representatives from the African diaspora and the resolutions and decisons made for political action. ${ }^{12}$

The National Association for the Advancement of Colored People (NAACP) founded in 1909, was organized by persons motivated by the continued need to do something about lynchings and blatant discrimination in America. The organization's anti-lynching agenda clearly evolved from the platform that was created during the nineteenth century. The NAACP expanded the tactical method of investigating lynchings that had been initiated by Wells-Barnett in 1892, as well as the tendancy to pressure the courts for legal action in specific cases of discrimination, as Albion Tourgee and the National Citizen's Rights Association (N.C.R.A.) had done during the Plessy v. Ferguson case, which began in 1891. Also when the Dyer Anti-lynching Bill came before Congress in 1921, extensive effort was made by the NAACP to encourage the passing of the bill. It was at that time that Walter White, working with the NAACP, made a "pilgrimage" to England as Wells-Barnett had in 1893 and 1894. White's specific purpose in going to England was to obtain support for the passage of the Dyer Anti-lynching

12 Ibid., 164. 
Bill. Historian Patricia Schechter notes that while White was in England, he was able to "mobilize the religious energy and grassroots appeal that WellsBarnett had tapped in her own earlier crusade."13

The nineteenth century anti-lynching campaign responded to a critical need to abolish a heinous crime in American society. Although lynchings were not totally abolished by the century's end, they did decline in number and were never again as high as they were in the early 1890s. This work provides a view of the continuum of trans-Atlantic anti-lynching activity in America and the United Kingdom from 1883 to 1900. It shows that the trans-Atlantic aspect of the movement pre-dates current studies by ten years, and it illustrates more definitively those who were involved in the movement from its inception to the end of the nineteenth century, making this dissertation a significant contribution to the prevailing pool of data on the anti-lynching movement.

13 Patricia A. Schechter, Ida B. Wells-Barnett \& American Reform, 1880-1930 (Chapel Hill: University of North Carolina Press, 2001), 122. 


\section{Selected Bibliography}

\section{Primary Sources}

\section{Manuscripts, Diaries, Letters}

The Ida B. Wells Papers. University of Chicago Reggenstein Library, Chicago, Illinois.

The Memphis Diary of Ida B. Wells. University of Chicago Reggenstein Library, Chicago, Illinois.

The 1930s Diary of Ida B. Wells. University of Chicago Reggenstein Library, Chicago, Illinois.

Catherine Impey, September 1890 Diary entry. Anti-Caste, 7 (April/May 1895): 14-16.

Ida B. Wells to Frederick Douglass, 17 October 1892. Ida B. Wells Papers, Special Collections, Reggenstein Library.

Ida B. Wells to Frederick Douglass, 18 March 1894. Ida B. Wells Papers, Special Collections, Reggenstein Library, University of Chicago.

Ida B. Wells to Frederick Douglass, 6 April 1894. Ida B. Wells Papers, Special Collections, Reggenstein Library, University of Chicago.

Ida B. Wells to Helen Douglass, 26 April 1894. Ida B. Wells Papers, Special Collections, Reggenstein Library, University of Chicago.

Ida B. Wells to Albion Tourgee, 24 November 1894. Ida B. Wells Papers, Special Collections, Reggenstein Library, University of Chicago.

Ida B. Wells to Albion Tourgee, 15 May 1897. Ida B. Wells Papers, Special Collections, Reggenstein Library, University of Chicago.

Catherine Impey to Frederick Douglass, 15 February 1883. Frederick Douglass Papers, General Correspondence File, Reel 3, Volume 5, Frames 689-697, Library of Congress, Washington D. C.

Catherine Impey to Frederick Douglass, 5 July 1887. Frederick Douglass Papers, General Correspondence File, Reel 4, Volume 6, Frames 576R-570L, 
Library of Congress, Washington D. C.

Catherine Impey to Frederick Douglass, 9 July 1887. Frederick Douglass Papers, General Correspondence File, Reel 4, Volume 6, Frames 588R-5902, Library of Congress, Washington, D. C.

Catherine Impey to Frederick Douglass, 4 September 1888. Frederick Douglass Papers, General Correspondence File, Reel 5, Volume 7, Frames 0F6R-080, Library of Congress, Washington D. C.

Catherine Impey to Frederick Douglass, 13 April 1889. Frederick Douglass Papers General Correspondence File, Reel 5, Volume 4, Frames 322-327, Library of Congress, Washington D. C.

Catherine Impey to Booker T. Washington, 5 March 1890. Harlan, Louis, ed. The Booker T. Washington Papers, Vol. 3, Urbana: University of Illinois Press, 1974.

Frederick Douglass to Charles Aked, 27 March 1894. Ida B. Wells Papers, Special Collections, Reggenstein Library, University of Chicago.

T. Thomas Fortune to Catherine Impey, 20 April 1887, reprinted in the New York Freeman, 20 May 1887.

\section{$\underline{\text { Periodicals }}$}

Anti-Caste. March 1888-May 1895.

Fraternity. June 1893-December 1897

The Friend. Vol. 64. 1924.

\section{Newspaper Articles}

Balgarnie, Florence. "Lynching in America." The Times, 9 November 1894: 7

Fortune, T. Thomas. " The Afro-American Agitator." New York Age, 21 December 1889.

. "A Proposed Afro-American League." New York Freeman, 
December 1887.

28 May 1887.

. "A Proposed Afro-American National League." New York Freeman,

. "On the Gridion." New York Freeman, 28 May 1887.

. "The Afro-American League." New York Age, 4 June 1887.

. "After War Times." New York Age, 13 August 1927.

. "American Color Prejudice." New York Freeman, 28 May 1887.

. "To the Colored Citizens of the Republic. New York Age, 4

November 1889.

. "Lynching in Maryland." New York Freeman, 6 December 1886, July 1887, 31 December 1887.

. "Maryland Lynchers Foiled." New York Age, 22 November 1890.

. "Determined Resistance To Mob Law At Annapolis." New York Age, 22 November 1890.

Garrison, William Lloyd, Jr. "The Anti-Lynching Committee." The Times,

9 November, 1894, 15.

"Lynch Law in the United States." Birmingham Daily Gazette, 18 May 1893, 6.

Wells, Ida B. "Afro-Americans and Africa." A.M.E. Church Review, July 1892, 40-45

. "Functions of Leadership." The Living Way, 12 September 1885.

- "The Model Woman: A Pen Picture of the Typical Southern

Girl." New York Freeman, 18 February 1888.

. "Our Women." The New York Freeman, 1 January 1887.

. "Women's Mission." New York Freeman, 26 Decmber 1885. 


\section{$\underline{\text { Journal Articles }}$}

Aked, Charles. "The Race Problem In America," The Contemporary Review 65 (January-June 1894): 818-827.

Impey, Catherine. "What Shall We Do With Our Apples?" Atonement (1892): 1-4.

Wells, Ida B. "Booker T. Washington and His Critics." World Today (April 1904): 518-521.

. "How Enfranchisement Stops Lynching." Original Thoughts Magazine (June 1910): 42-53

. "Lynching and the Excuse For It." Independent (16 May 1901): 1133-1336.

. "Lynch Law in America." Arena (January 1900): 15-24.

. "The Negro's Case in Equity." Independent (26 April 1900): 1010-1011.

. "Our Country's Lynching Record." Survey, (1 February 1913): 573-574

\section{$\underline{\text { Books }}$}

Blassingame, John and John R. McKivigan. eds. The Frederick Douglass Papers: Series One; Speeches, Debates, and Interviews; Vol.5, 1881-1895. New Haven: Yale University Press, 1992.

Brown, William Wells. The American Fugitive in Europe: Sketches of Places and and People Abroad. New York: Negro Universities Press, 1855, reprinted in 1969.

. Three Years in Europe: Places I Have Seen and People I Have Met. London: Charles Gilpin, 1852.

Cable, George W. The Negro Question: A Selection of Writings on Civil Rights in the South. Garden City: Double Day \& Company, Inc., 1958.

Decosta-Willis, Miriam, ed. The Memphis Diary of Ida B. Wells. Boston: Beacon Press, 1995.

Duster, Alfreda M., ed. Crusade For Justice: The Autobiography of Ida B. Wells. Chicago: The University of Chicago Press, 1970. 
Foner, Philip. The Voice of Black America: Major Speeches by Negroes in the United States, 1797-1971. New York: Simon and Shuster, 1972.

Halliburton, Warren J. Historic Speeches of African Americans. New York:

The African American Experience, Franklin Watts,1993.

Lynch, John R. The Facts of Reconstruction. New York, 1913. Reprint, North Stratford, New Hampshire: Ayer Company Publishers, Inc., 1969.

Mayo, Isabella Fyvie. Recollections of Fifty Years: What I Saw, What I Lived Through, and What I Learned, During More Than Fifty Years of Social and Literary Experience. London: John Murry, 1910.

Sterling, Dorothy. ed. We Are Your Sisters: Black Women in the Nineteenth Century. New York: W. W. Norton and Company, 1984.

Terrell, Mary Church. A Colored Woman in a White World. Washington, D. C.: Ransdelling Publishers Inc., 1940.

Tourgee, Albion. A Fool's Errand by One of the Fools. John Hope Franklin. ed. Cambridge: Harvard University Press, 1961. . Bricks Without Straw. Otto H. Olsen. ed. Baton Rouge: Louisianna State Press, 1969.

. The Invisible Empire: A Concise Review of the Epoch. (1883) Ridgewood, New Jersey: Gregg Press, 1968.

Walters, Alexander. My Life and Work. New York: Fleming H. Revell, 1917.

Wells, Ida B. Southern Horrors: Lynch Law in All Its Phases. New York: New York Age Printers, 1892. . The Reason Why the Colored American is Not in the World's Columbian Exposition. Chicago: Ida B. Wells, 1893. . A Red Record. Chicago: Donohue \& Henneberry, 1895. . Mob Rule in New Orleans. Chicago, 1900. Reprinted in On Lynchings. Salem: Ayer Company Publishers, 1993. 


\section{Secondary Sources}

\section{Unpublished Works}

Beyan, Amos Jones. "The American Colonization Society and the Formation of Political, Economic, and Religious Institutions in Liberia, 1822-1900." Ph.D diss., West Virginia University, 1985.

Carey, Thomas. "Albion Winegar Tourgee: Altruist or Cynic." Ph.D. diss., St. John's University, 1950.

Hutton, Mary Magdeline Boon. "The Rhetoric of Ida B. Wells: The Genesis of the AntiLynch Movement." Ph.D diss., Indiana University, 1975.

Slocum, Terry A. "Timothy Thomas Fortune: A Negro in American Society." M. A. Thesis, Princeton University, 1967.

Townes, Emilie Maureen. "The Social and Moral Perspectives of Ida B. Wells-Barnett As Resources For A Contemporary Afro-Feminist Christian Social Ethic." Ph.D diss., Northwestern University, 1989.

\section{$\underline{\text { Books }}$}

Allen, James et al., eds., Without Sanctuary: Lynching Photography In America. San Francisco: Twin Palms Publishers, 2000.

Anderson, James D. "Ex-slaves and the Rise of Universal Education in the South, 1860-1880." In The Education of Blacks in the South, 18601935. Chapel Hill: The University of North Carolina, 1988.

Andrews, William L. ed. The Oxford Frederick Douglass Reader. Oxford: Oxford University Press, 1996.

Aptheker, Herbert. ed. A Documentary History of the Negro People of the United States. New York: Citadel Press, 1951.

Bennett, Lerone. Before the Mayflower: A History Of Black America. Middlesex, England: Penquin Books Ltd., 1961.

Berry, Mary Francis John W. Blassingame. Long Memory: The Black Experience in America. New York: Oxford University Press, 1982.

Blackett, R.J.M. Building an Antislavery Wall. Ithaca: Cornell University 
Press, 1983.

Blight, David W. ed. Narrative of the Life of Frederick Douglass. Boston: Bedford Books, 1993.

Bloom, Jack M. Class, Race. \& The Civil Rights Movement. Bloomington: Indiana University Press, 1987.

Bracey, John. Blacks in the Abolitionist Movement. Belmont: Wadsworth Publishing Company, 1971.

Brown, Kenneth D. The English Labour Movement. New York:

St. Martin's Press, 1982.

Brown, Mary Jane. Eradicating This Evil: Women In The American Anti-Lynching Movement, 1892-1940. New York: Garland Publishing Company, 2000.

Craig, Gordon A. Europe Since 1815. New York: Harcourt Brace, 1974.

Cutler, James Elbert. Lynch Law: An Investigation into the History of Lynching in the United States. New York: Negro University Press, 1905.

Daniels, Sadie and Hallie Quinn Brown. Women Builders. Washington, D.C.: Associated Publishers, 1970.

Dibble, Roy F. Albion W. Tourgee. Port Washington: Kennikat Press Inc., 1921.

Dillon, Merton L. Southern Slaves and Their Allies, 1619-1865. Baton Rouge: Louisianna State University Press, 1900.

DuBois, W. E. B. Black Reconstruction in America, 1869-1880. New York: Harcourt, Brace, 1935. . The Souls of Black Folk: Essays and Sketches. Chicago: A. C. McClurg, 1903.

Estell, Kenneth. African America: Celebrating 400 Years of Achievement. Detroit: Visible Ink Press, 1994.

Farrison, Edward W. William Wells Brown: Author and Reformer. Chicago: University of Chicago Press, 1969.

Foner, Eric. Reconstruction: America's Unifnished Revolution, 1863-1866. New York: Harper \& Row, 1988. 
Foner, Philip S. Frederick Douglass. New York: Citadel Press, 1969.

Fortune, T. Thomas. Black and White: Land, Labor, and Politics in the South. 1884; New York: Arno Press, 1968.

Fox, Stephen R. The Guardian of Boston: William Monroe Trotter. New York: Atheneum, 1970.

Franklyn, John Hope and August Meier. eds. Black Leaders of the Twentieth Century. Urbana: The University of Illinois Press, 1982.

Franklyn, John Hope. From Slavery to Freedom. 6th. ed. New York: McGraw-Hill, Inc., 1988.

. George Washington Williams: A Biography. Chicago:

University of Chicago Press, 1985.

Fraser, Antonia. The Lives of Kings and Queens of England. London:

Weidenfeld and Nicholson, 1975.

Gates, Henry Louis and Cornell West. The African American Century: How Black Americans Have shaped Our Country. New York: The Free Press, 2000.

Genovese, Eugene D. Roll Jordan Roll: The World The Slaves Made.

New York: Vintage Books, 1972.

Giddings, Paula. When and Were I Enter: The Impact of Black Women On Race and Sex in America. New York: William Morrow and Company, Inc., 1984.

Grant, Donald L. The Anti-Lynching Movement, 1883-1932. San

Francisco: R. E. Reseach Associates, 1975.

Gross, Theodore L. Albion W. Tourgee. New York: Twayne Publishers, inc., 1963.

Gunning, Sandra. Race, Rape, and Lynching: The Red Record of American Literature, 1890-1912. New York: Oxford University Press, 1996.

Gutman, Herbert. The Black Family in Slavery and Freedom, 1750-1925. New York: Pantheon Books, 1976.

Harlan, Louis. Booker T. Washington: The Making of a Black Leader, 1856-1901. New York: Oxford University Press. 1972.

Hearder, Harry. Europe in the Nineteenth Century, 1830-1880. 2nd ed. London: 
Longman, 1966.

Hunt, James D. Gandhi in London. New Delhi: Promilla \& Company Publishers, 1978.

Karenga, Maulauna. Introduction to Black Studies, 2nd. ed. Los

Angeles: The University of Sankore Press, 1993.

Lafontant, Jewel. ed. A Salute to Historic Black Women. Chicago:

Empak Enterprises, 1984.

Lewis, David Levering. W. E. B. DuBois: Biography of a Race, 1868-1919. New York: Henry Holt, 1993.

Litwack, Leon F. "Hellhounds," in Trouble In Mind: Black Southerners in the Age of Jim Crow. New York Alfred Knopf, 1998.

Marable, Manning. W.E.B. DuBois: Black Radical Democrat. Boston: Twayne Publishers, 1986.

McFadden, Margaret H. Golden Cables of Sympathy: The Transatlantic Sources of Nineteenth Century Feminism. Lexington: University Press of Kentucky, 1999.

McMurry, Linda O. To Keep the Waters Troubled: The Life of Ida

B. Wells. New York: Oxford University Press, 1998.

McPherson, James. The Negroes Civil War: How American Blacks Felt and Acted During the War of the Union. New York: Ballentine Books, 1991.

, The Abolitionist Legacy: From Reconstruction to the NAACP. Princeton:

Princton University Press, 1975.

Meier, August. Negro Thought in America, 1880-1915: Racial Ideologies in the Age of Booker T. Washington. Ann Arbor: The University of Michigan Press, 1966. , and Elliot Rudwick. From Plantation to Ghetto. 3rd. ed. New York: Hill and Wang, 1966.

, Elliot Rudwick, and Francis L. Broderick. Black Protest Thought in the Twentieth Century, 2nd ed. Indianapolis: Bobbs-Merrill Educational Publishing, 1965.

Olsen, Otto H. Carpetbagger's Crusade: The Life of Albion Winegar Tourgee. Baltimore: John Hopkins Press, 1965.

Painter, Nell Irvin. Exodusters: Black Migration to Kansas After 
Reconstruction. New York: Alfred A. Knopf, 1976.

Penn, I. Garland. The Afro-American Press and Its Editors. 1891; New York: Arno Press, 1969.

Porter, Andrew. ed. The Oxford History of the British Empire; Vol. 3, The Nineteenth Century. Oxford: Oxford University Press, 1999.

Porter, Bernard. The Lion's Share: A Short History of British Imperialism. London: Longman, 1975. - Critics of Empire: British Radical Attitudes to Colonialism in Africa. London: Macmillan, 1988.

Rodney, Walter. How Europe Underdeveloped Africa. Washington: Howard University Press, 1982.

Royster, Jaqueline Jones. ed. Southern Horrors and Other Writings: The Anti-Lynching Campaign of Ida B. Wells, 1892-1900. Boston: Bedford Books, 1997.

Salem, Dorothy. To Better Our World: Black Women in Organized Reform, 1890-1920. Brooklyn: Carlson Publishing, Inc., 1990.

Schechter, Patricia A. Ida B. Wells-Barnett and American Reform, 1880-1930. Chapel Hill: The University of North Carolina Press, 2001.

Scobie, Edward. Black Brittania: A History of Blacks in Britain. Chicago: Johnson Publishing Company Inc., 1972.

Sewell, George A. and Margaret L. Dwight. Mississippi Black History Makers. Jackson: University Press of Mississippi, 1984.

Shay, Frank. Judge Lynch: His First Hundred Years: New York: Ives Washburn, Inc., 1938

Sklar, Katerine Kish and Thomas Dublin. eds. Women and Power in American History: A Reader, Vol. 11. Englewood Cliffs, N. J.: Prentiss Hall, 1991.

Smith, John David. An Old Creed For the New South. Athens: The University of Georgia Press, 1985.

Spear, Allen H. Black Chicago: The Making of a Negro Ghetto, 1890-1920. Chicago: University of Chicago Press, 1976.

Sterling, Dorothy. Black Foremothers: Three Lives. New York: The Feminist 
Press, 1988.

Streitmatter, Rodger. Raising Her Voice: African-American Women Journalists Who Changed History. Lexington: The University of Kentucky Press, 1994.

Takaki, Ronald. Iron Cages: Race and Culture in 19th Century America. New York: Oxford University Press, 1990.

. A Different Mirror: A History of Multicultural America.

Boston: Little Brown and Company, 1993.

Thompson, Mildred I. Ida B. Wells-Barnett: An Exploratory Study of An American Black Woman, 1893-1930. Brooklyn: Carlson Publishing Inc., 1990.

Thornbrough, Emma Lou. T. Thomas Fortune: Militant Journalist:

Chicago: University of Chicago Press, 1972.

- Black Reconstructionists: Great Lives Observed.

Englewood Cliffs: Prentiss Hall, 1972.

Tolney, Stewart E. and E. M. Beck. A Festival of Violence: An Analysis of Southern

Lynchings, 1882-1930. Urbana: University of Illinois Press, 1995.

Ware, Vron. Beyond the Pale: White Women, Racism and History. London: Verso, 1992.

Washington, Booker T. Up From Slavery. New York: Magnum Books, 1968.

Wesley, Charles. A History of the National Association of Colored Women's Clubs: A Legacy of Service. Washington, D.C.: National Association of Colored Women's Clubs, Inc., 1984.

Wharton, Vernon L. The Negro in Mississippi. New York: Harper \& Row, 1947.

White, Walter. Rope and Faggot: A Biography of Judge Lynch. New York: Alfred Knopf, 1929.

Woodson, Carter G. The Mis-education of the Negro. Washington, D. C.:

Associated Publishers, Inc., 1969. 


\section{Newspaper Articles}

Baltimore Correspondent. "Lynching in Maryland." New York Freeman, July 1887.

Barclay, Delores, Todd Lewan, and Allen G. Breed. "Landownership Meant Death for Many Blacks." Charleston Gazette, 3 December 2001, 1A.

"Ready For the Fair." The New York Times, 1 May 1893.

"Lynchers At Duluth." The New York times, 7 May 1893.

"Hung On A Hickory Tree." The New York Times, 11 May 1893.

"Miss Wells's Plea For the Lynchers." New York Times, 30 July 1894

"British Anti-lynchers." The New York Times, 2 August 1894

"Ida B. Wells Abroad." Chicago Inter-Ocean, 9 April 1894.

\section{Journal Articles.}

Adams, Samuel L. "Ida B. Wells: A Founder Who Never Knew Her Place." Crisis, (January 1994): 43.

Boyd, Joyce. "Review Essay: Cannon Configuration for Ida B. Wells-Barnett." Black Scholar, 24 (Winter 1991): 8-20.

Bullock, Penelope. "Profile of a Periodical: The Voice of the Negro." The Atlanta Historical Bulletin, 13, no. 2 (June 1968).

Butcher, Philip. "George Washington Cable and George Washington Williams: An Abortive Collaboration." The Journal of Negro History, 53, no. 4 (October 1968): 334-344.

Carby, Hazel V. " On the Threshold of Women's Era: Lynching, Empire, and Sexuality in Black Feminist Theory." Critical Inquiry 12 (Autumn 1985): 262-275.

Davis, Simone W. "The 'Weak Race' and the Winchester: Political Voices in Pamphlets of Ida B. Wells-Barnett." Legacy 17, no. 2 (1995): 77-89.

Devin, William A. "Footprints of a Carpetbagger." The Torch 17, (April 1944): 16. 
Gross, Theodore. "The Fool's Errand of Albion W. Tourgee." Phylon, (Fall 1963): 240-254.

Lerner, Gerda. "Community Work of Black Club Women," in Journal of Negro History. 59, no. 2 (April 1974): 158-167.

Logan, Shirley L. "Rhetorical Strategies In Ida B. Wells's Southern Horrors: Lynch Law In All Its Phases." Sage 8, no. 1 (Summer 1991): 3-8.

Sibthorp, Margaret Shurmer. "Vegetarianism," Shafts: A Paper For Women \& the Working Classes, 2, no. 11 (January 1893): 205.

Thornbrough, Emma Lou. "The National Afro-American League, 1887-1908." Journal of Southern History, 27, no. 4 (February 1961): 494-512.

\section{Videos and Websites}

Public Broadcasting Service. The American Experience. Ida B. Wells: A

Passion For Justice, Boston, New York, Los Angeles: PBS, 1990.

Battle, Ursula V. "Fannie Jackson Coppin: An Educator With a Lasting Legacy." $\mathrm{http} / / \mathrm{www} \cdot$ btimes.com/blackhistory/3-6-98coppin1.html

Britannia Government: "Prime Ministers." Archiblad Philip - Primrose Rosebury http://www.britannia.com/gov/primes/prime38.html 